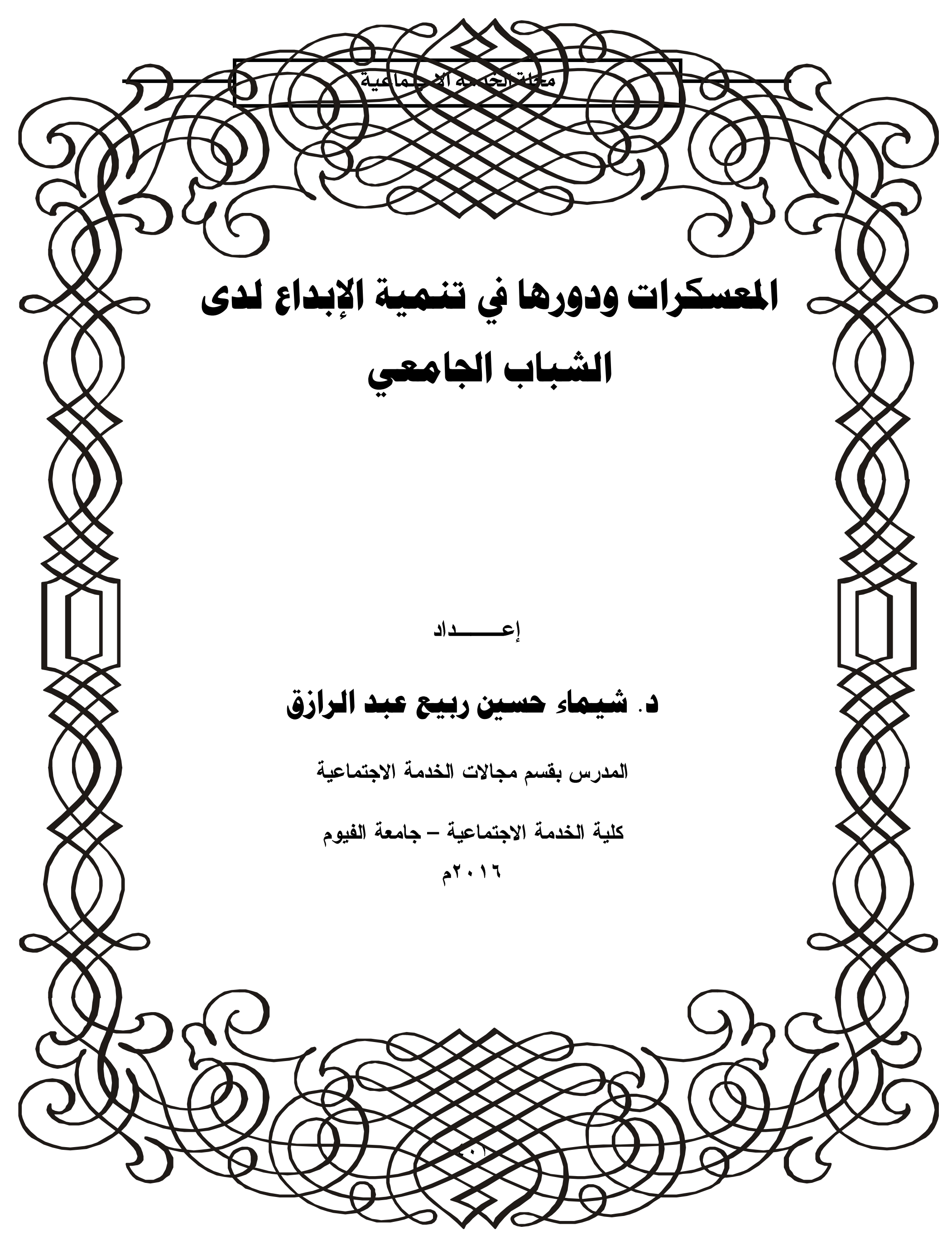


- 


\section{لمـلة الخدمة الاجتماعية}

أولا: مشكلة الدراسة.

تعتبر تتمية الموارد البشرية من القضايا المهمة التي تهتم بها كافة المجتمعات الإنسانية المنقدمة و النامية على حد سواء، وذلك لما لها من أهمية في تحسين أوضاع المجتمعات وتحقيق مستوى حياة أفضل للإنسان لأنهم قادرين على احداث التغيير المطلوب.

ويعد الشباب من أهم عناصر الموارد البشرية الذي تعتمد عليه الدولة من أجل نجاح خطط التتمية، وهو المحرك الأساسي لكافة مقوماتها وهو أساس كل ثقدم يمكن أن يتحقق في أبي مجتمع من المجتمعات

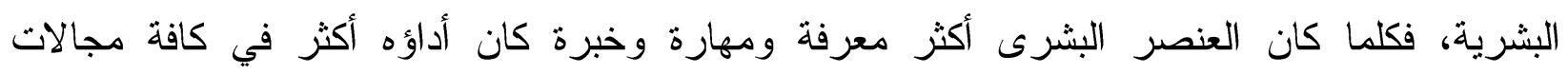

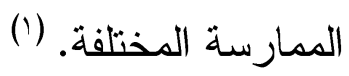

كما يمكن النظر الى مرحلة الثباب وخاصة الثباب الجامعي على أنها مرحلة عمرية تنشأ كمصلة تفاعل عو امل بيولوجية مع خصائص نفسية في سياق عناصر ومحددات ثقافية واجنماعية باعتبار أن الثباب هو أقص درجات الحيوية بيولوجيا وفيزيقيا وعقليا ونفسيا واجتماعيا، وعلى ذلك يمكننا الاستفادة

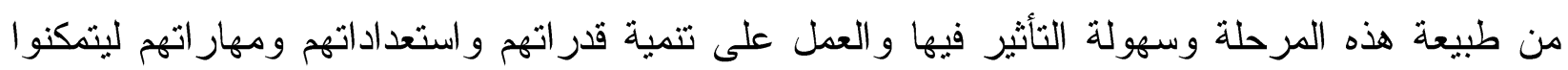

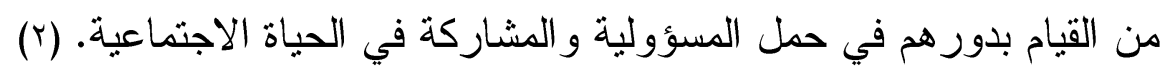
وبالتالي فإن الاهتمام بإبداع الثباب يعتبر من أعظم أثكال الحياة العقلية الأكثر دقة، فالتربية الإبداعية

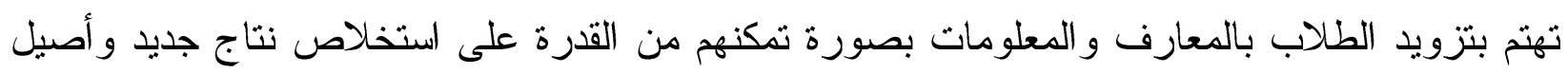

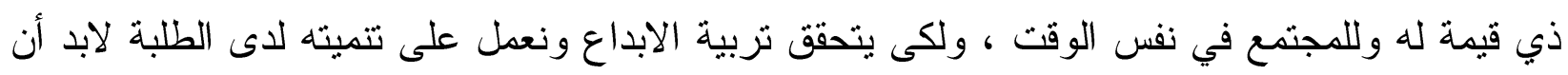

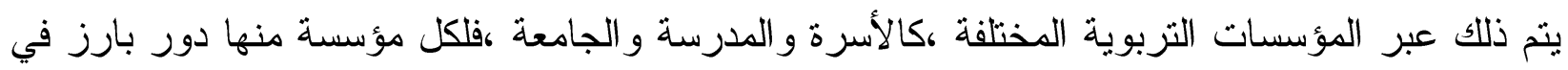

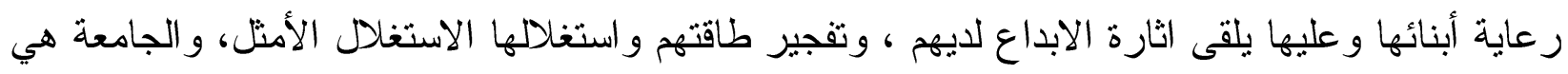

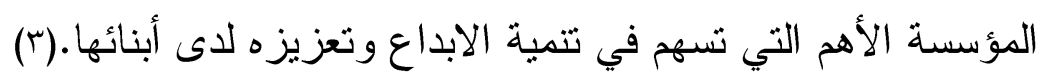
وفى هذا الاتجاه لابد من تشجيع الثباب الجامعي على ممارسة التفكير السليم بما له من أهمية خاصة في كل المجتمعات حيث أن إطلاق الطاقات البشرية بكل قوتها نحو الابتكار يعتبر من أهم متغيرات العامل

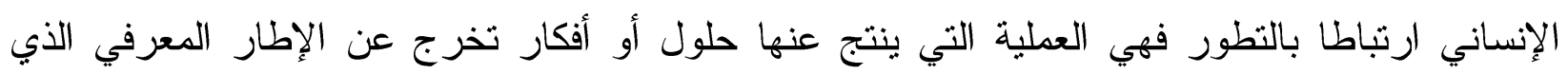

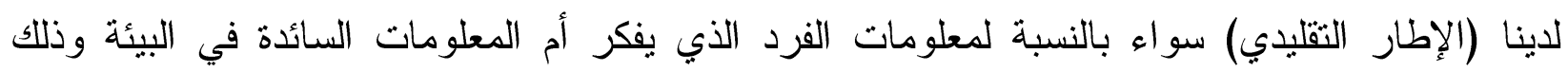

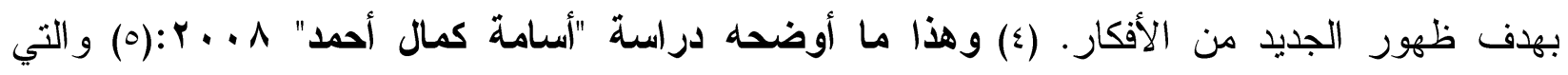

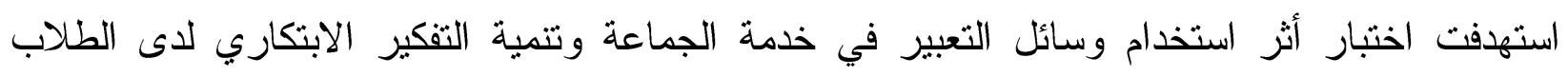
وتوصلت الدراسة أن عند اكتساب الطلاب للمعارف عن طريق وسائل التعبير المختلفة يتولد لديهم الأفكار الجديدة والتي تتسم بالأصالة و المرونة وأيضا عند استخدام استر اتيجيات مختلفة كالعصف الذهني وحل 


\section{لمـلة الخدمة الاجتماعية}

المشكلة تزداد لديهم القدرة على انتاج أفكار عديدة وهو ما يسمى بالطلاقة في التفكير الابتكاري. كما أن

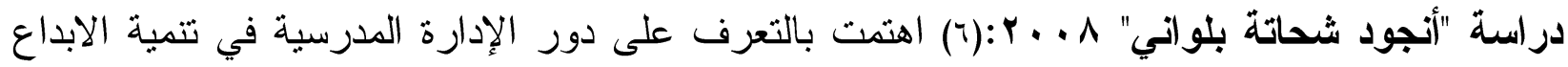
في المدارس الحكومية وقد توصلت الدراسة الى ضرورة تطوير البرامج التعليمية وتضمينها ما يدعو الى لإلى

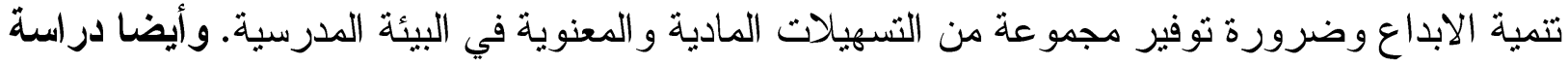

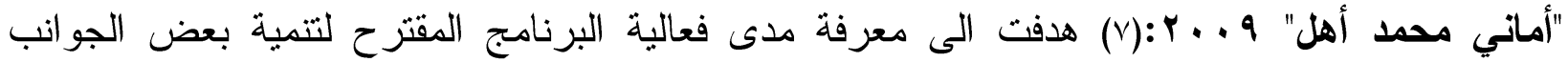

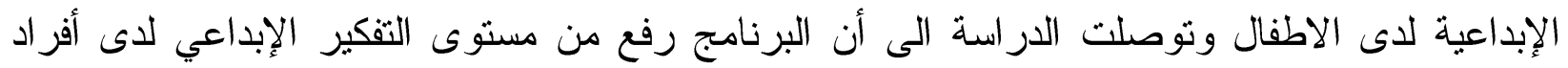

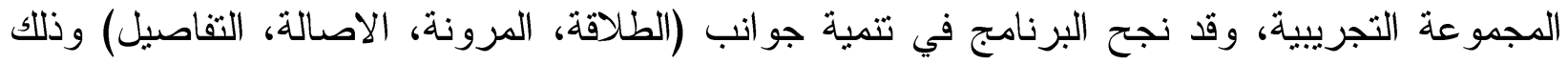
من خلال أنشطة متعددة ومختلفة بطريقة اللعب و المسرح و العصف الذهني الممزوج بالتشيط. كما أن

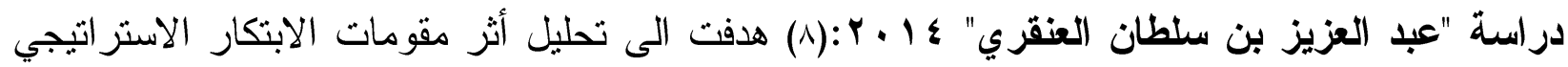
في تحسين ممارسات إدارة الموارد البشرية وقد اظهرت نتائج الدراسة أن هنالك اهتماما من المسئولين

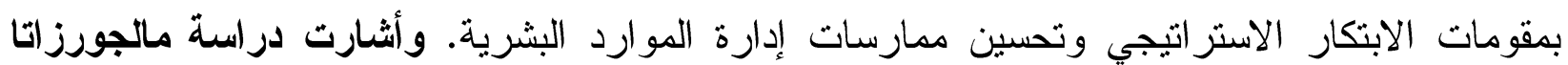

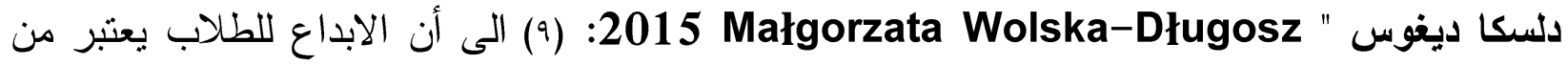
الأهداف الهامة التي ينم التركيز عليها في الانشطة التعليمية مما تساهم في تشكيل سمات شخصية الطلاب

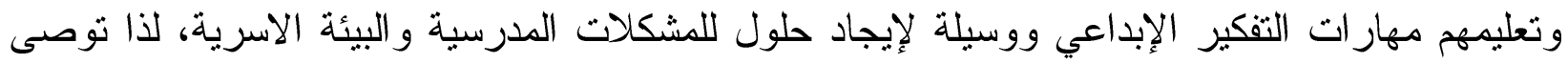

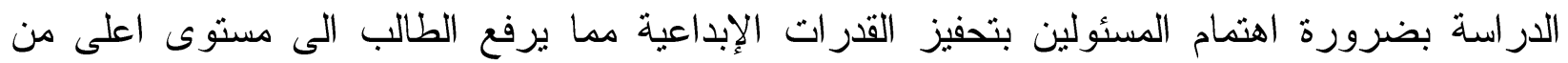

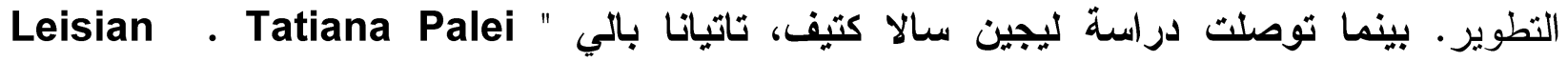
2015 Salakhatdinova الدورات التدريبية والبرامج التي تعزز الابداع لدى الطلاب وذللك من خلال فحص المناهج و المخرجات

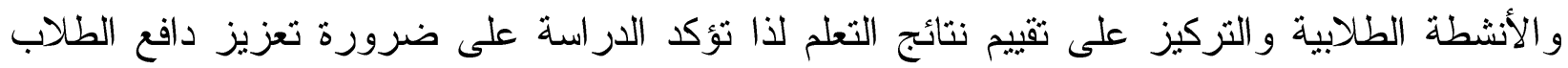

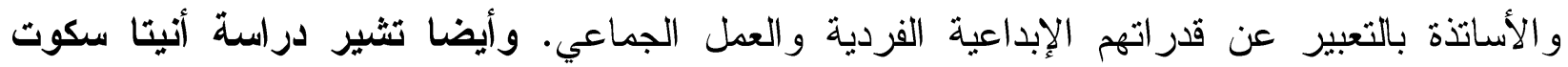
وآخرون “"2015:Aneta Sokól etal) (1) الى أن الابداع هو واحد من أهم العوامل لتتمية العنصر

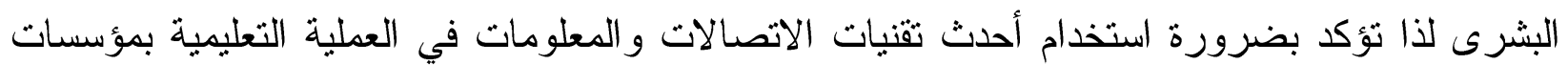

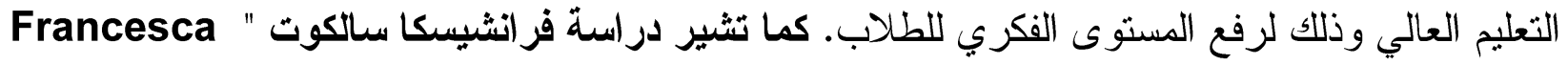
2015:(r) Saliceti المعارف الجديدة و اكتساب سلوكيات جديدة لذا توصى الدراسة بضرورة تطور أبعاد جديدة لطرق التدريس و التعلم وخلق طرق جديدة للتو اصل و استراتيجيات تعليمية مبتكرة وذلك لتعلم الطلاب الأسلوب الإبداعي و الابتكاري. 


\section{لمـلة الخدمة الاجتماعية}

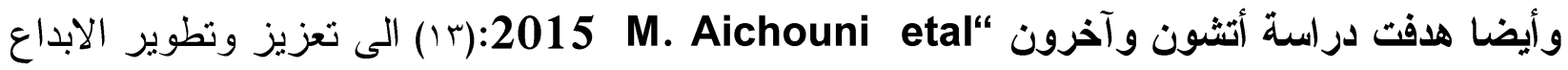
و الابتكار بين الطلاب في كل من المدرسة والجامعة كما هدفت أيضا الى تثيبم الابداع و الابتكار في النظام التعليمي من وجهه نظر عملائها وتوصلت الدراسة الى ضرورة الاعتماد على استر اتيجيات جديدة لتعزيز

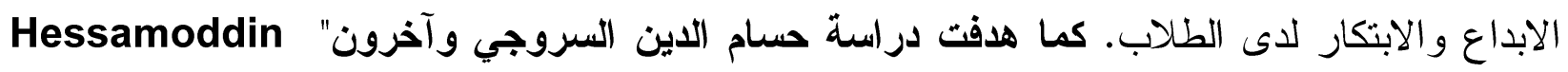
2015 Sarooghi etal

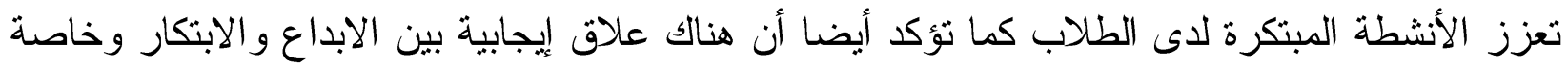
على المستوى الفردي لذا توصى الدراسة بتقديم كافة المقترحات لتدعيم الابداع و الابتكار ات في جميع

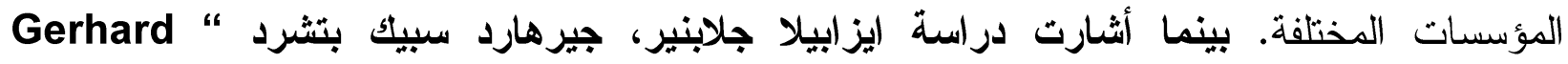

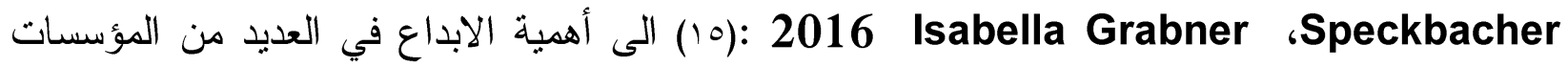
الاجتماعية المختلفة وذلك لرفع معدلات تقييم الأداء والقدرة على تحمل مخاطر العمل مما يؤدى الى زيادة الإنتاج.

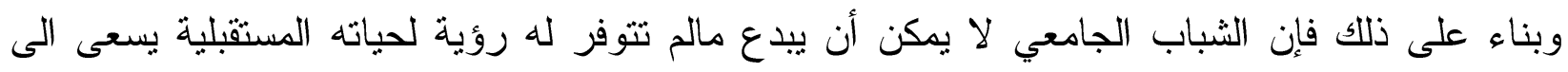

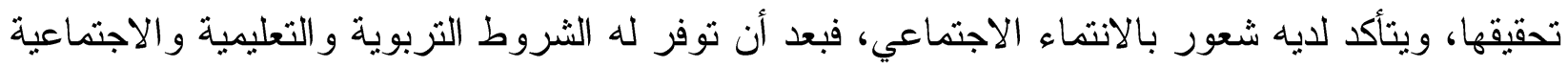

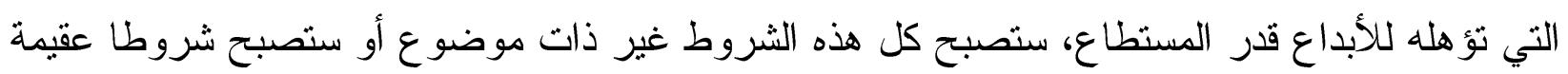

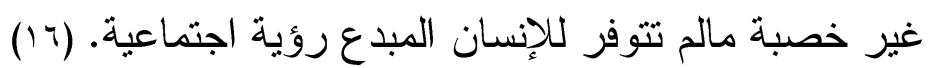
و هذا التحقق مشروط بنسق تعليمي متميز، يتجاوز حدود الحفظ والتلقين والاتباع واستظهار المعلومات،

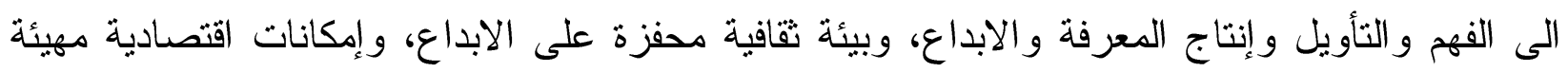

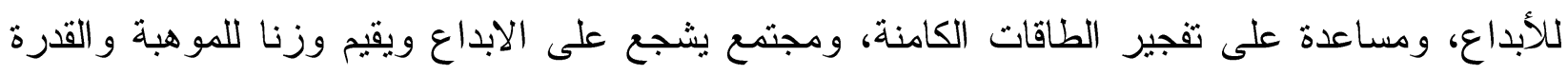

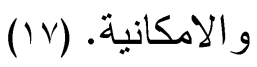

و انطلاقا من ذللك تحرص الجامعات على تنظيم معسكرات تدريبية يشارك فيها الثباب الجامعي حيث

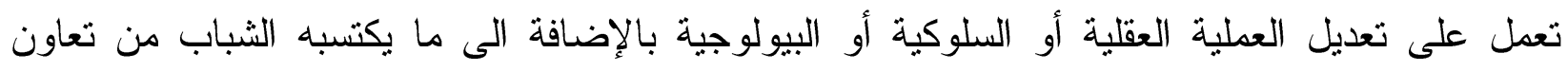

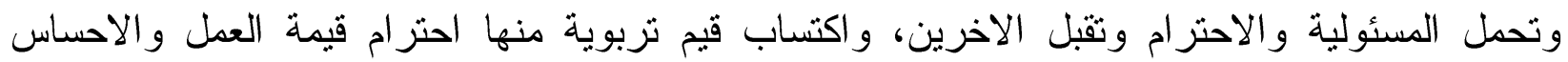

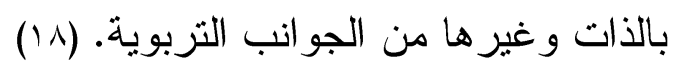

ولهذا فأن المعسكرات تعتبر من الأدوات الأساسية التي يمكن بواسطتها تعليم الثباب طرقا جديدة للتفكير و السلوك و التي تهدف برامجها الى مقابلة حاجات الافر اد وتحقيق تتمية شخصياتهم وتتمية قدر اتهم و التزود بالخبرات الجماعية، فضلا عن ذلك غرس القيم الاجتماعية كالعدل والصدق والأمانة واحترام مر اعاة

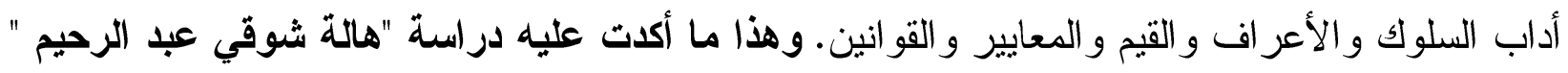




\section{لمـلة الخدمة الاجتماعية}

؟ . . Y : (9) و التي هدفت إلى معرفة مدى فاعلية أنشطة المعكرات لتعديل أنماط السلوك غير المرغوب فيه لدى طالبات رياض الأطفال المستجدات المقيمات بالمدينة الجامعية بجامعة حلوان ، وقد تم التطبيق

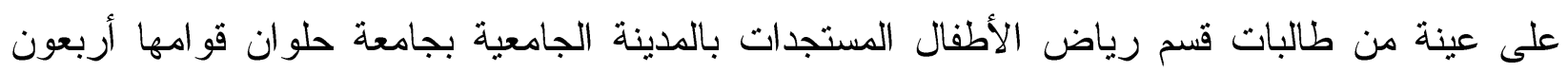
طالبة ، وتم تقسيمها إلى مجموعتين (تجريبية وضابطة) قوام كل منها عشرون طالبة ، وقد أسفرت

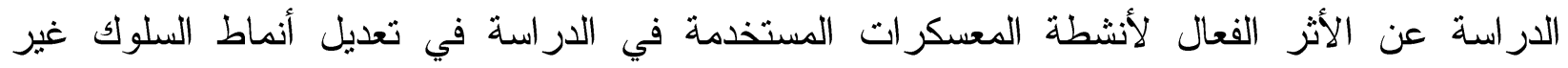

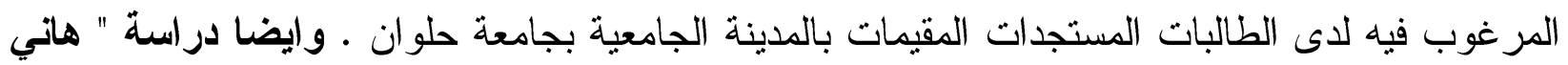

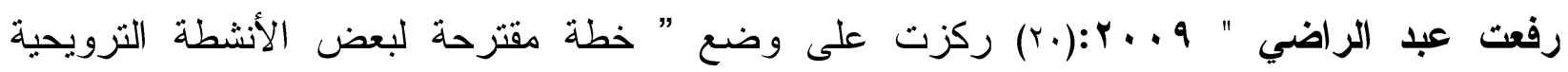
بمعسكرات الشباب كمدخل لتطوير المعسكرات القومية للشباب بجمهورية مصر العربية وتوصلت الدراسة الى وجود عقبات وصعوبات تحول دون التخطيط لتحقيق الأهداف المحددة والموضوعة من قبل إدارة

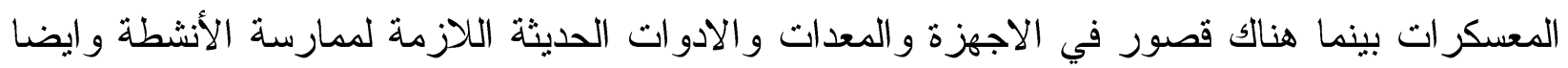
أن بر امج الأنشطة الترويحية لا تتفق مع احتياجات الممارسين. كما اهتمت دراسة جامعة لوس النجلوس ولئه

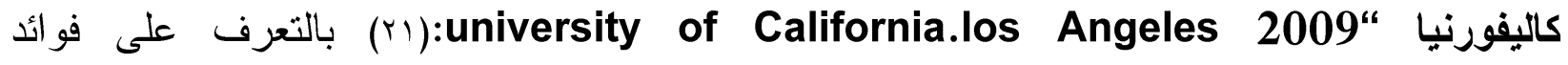
المعسكرات ودورها في مواجهة احتياجات الثباب، وأوصت الدراسة بضرورة التركيز على مواجهة

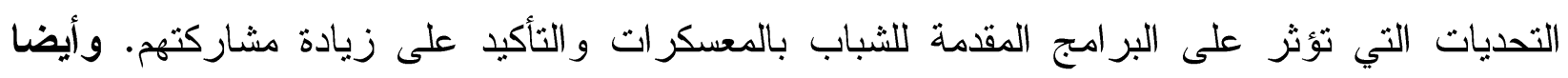

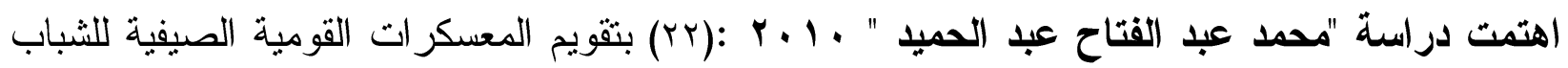
في جمهورية مصر العربية وأشارت أهم نتائج الدراسة إلى أن المعسكرات القومية تقدم خبرة و اقعية يمكن

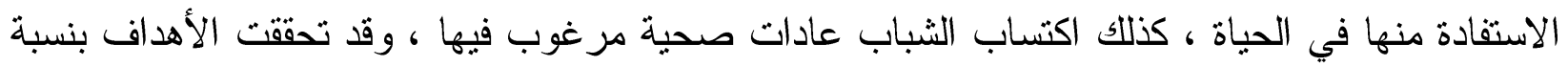

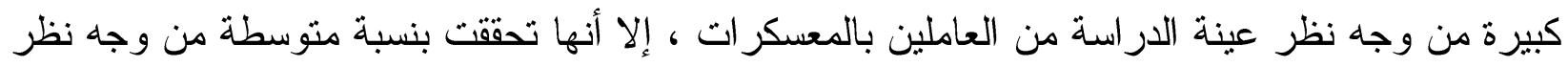

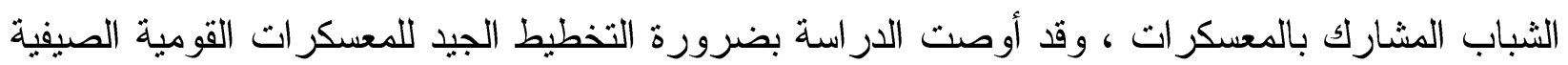

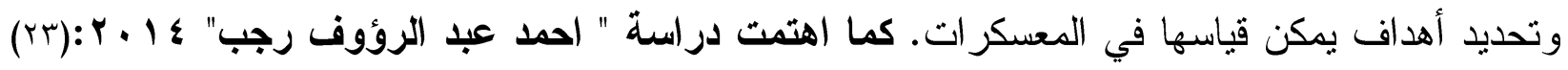
بتقويم العمليات الادارية للمعكر ات الكثفية لطلاب جامعة الاسكندرية وتوصلت نتائج الدر اسة الى وجود قصور في عملية التخطيطي من حيث (الاهداف، السياسات، الاجراءات، البرنامج الزمنى، الأكانات) و عملية التنظيم من حيث (الهيكل التنظيمي، الدعامات، المسؤوليات، السلطة، تقسيم العمل، الاشراف) و عملية التوجيه من حيث (القيادة والاتصال والدافعية) وعملية الرقابة من حيث (تحديد المعايير الرقابية،

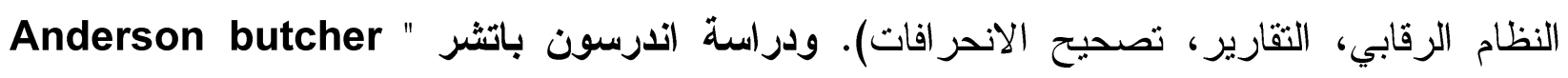

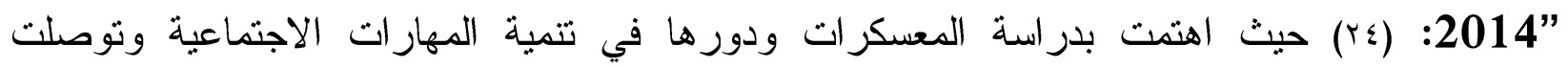
الدراسة الى أهمية المعسكرات في تعزيز الثعور بالانتماء لاى الثباب. ودراسة " عمرو رمضان سعد 


\section{لمـلة الخدمة الاجتماعية}

عثمان" ه 1 ـ r : (ro) هدفت إلى التعرف على مستوى المشاركة في المعسكرات التزويحية وعلاقتها بالمسئولية الاجتماعية وتقدير الذات لدى طلاب جامعة المنصورة، وكانت من أهم النتائج التي توصلت لها لهات الدراسة هي إدراك طلاب الجامعة لأهمية المشاركة في المعسكرات الترويحية ، كما أن فرص وصن تمكين الطلاب في وضع برنامج المعسكر" ضئيلة جدا وقد تكون غير موجوده بسبب لوائح الأنشطة الطلابية و التي لم يتم تغير ها منذ فترة زمنيه طويله و عدم المرونة في هذه اللوائح و النظام الروتيني المتبع وقصر

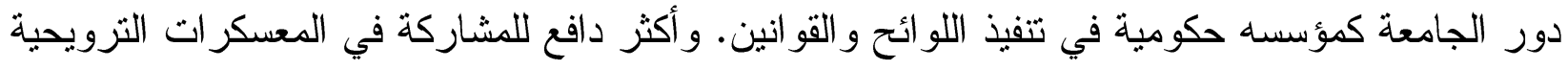

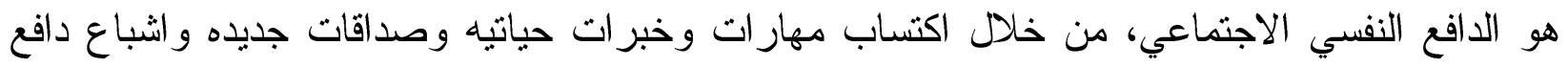

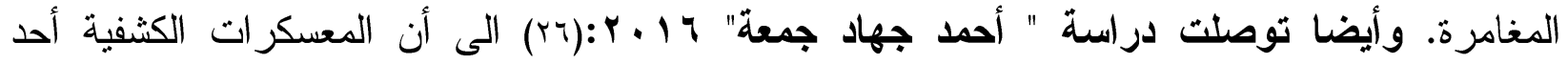
مجالات التتشئة الاجتماعية، التي تتيح للنشء فرص النمو المتكامل عن طريق ما توفره من خبرة تتكون من (معرفة، مهارة، اتجاهات)، وخبرات اجتماعية تساعدهم على التفاعل الديناميكي وتزودهم بالاتجاهات

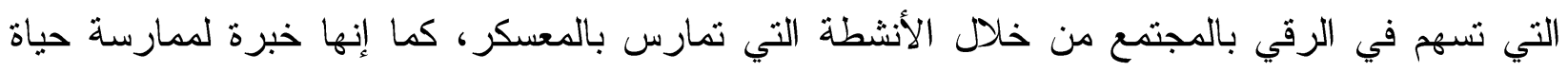
الجماعة في بيئة طبيعية لمدة معينة تحت إثراف ريادة مؤهي هلة لتوفير خبرة تربوية تتسم بالابتكار

و الابداع.

ومن هنا يأتي أهمية المعسكرات لتتمية الابداع لدى طلابها بصورة أساسية، لأننا عن طريق هذه التتمية ننمي فيه الاصالة ونكون به شخصيته، ونستطيع أن نغرس فيه الطموح وحب الفضائل، و الاهتمام بالعلم، وحب المعرفة، و الالتز ام بالمسؤولية، وحب العمل و الاستقامة. (rV) لللك يمكن للخدمة الاجتماعية احداث تغيير مقصود في الافراد والجماعات من أجل تتمية القدرات

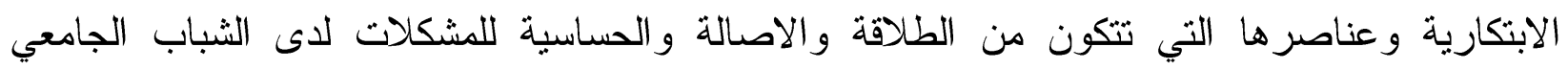
وكذلك تتمية الاتجاهات الإيجابية والقيم البناءة وامدادهم بالمعارف و المهار وات المختلفة و إيجاد وخلق فرص لمشاركتهم ومساعدتهم في تحقيق أهدافهم والمساهمة في تدعيم المسئولية الاجتماعية لديهم ومساعدتهم على اختيار البر امج الملائمة لتتمية قدر اتهم الابتكارية. (r^)

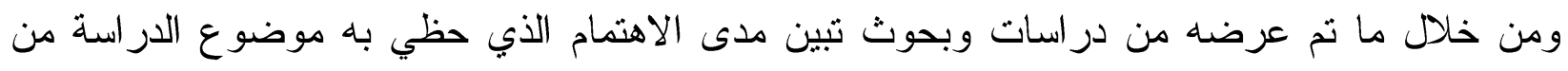
تقدير أهمية الابداع لاى الطلاب وما تتميز به تلك المرحلة من طاقات تحتاج الى توجيه حتى نرتقي بهم

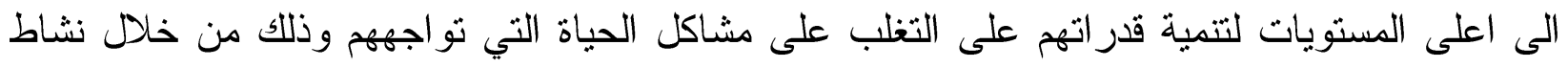
المعسكرات الذي يعتبر الركيزة الأساسية لأطلاق مواهبهم و إيداعاتهم في انجاز الاعمال ورفع مستوى

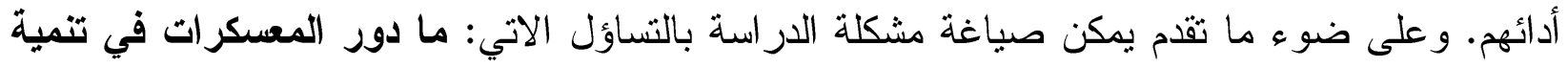




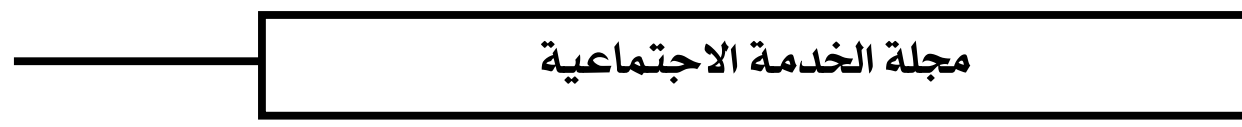

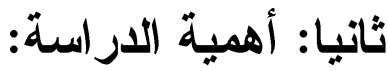

ترجع أهمية الدراسة إلى عدة اعتبارات أساسية منها: -

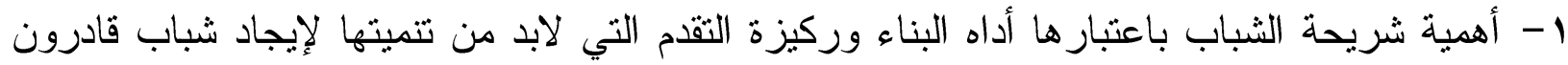

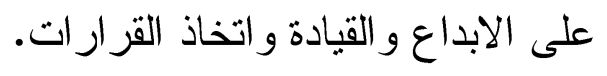

ץ- تتبع أهمية الدراسة من أهمية الابداع لدى الثباد الثبات الجامعي في العملية التربوية والتعليمية باعتبارهم

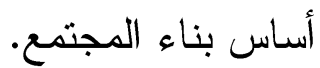

ب- أهمية تحديد أنسب الأساليب والوسائل المناسبة لتتمية الجو انب المختلفة من شخصية الثباب الجامعي.

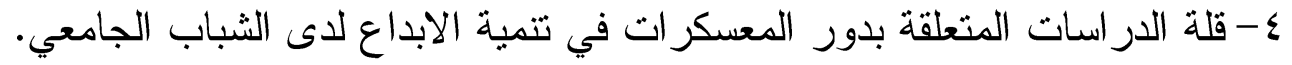

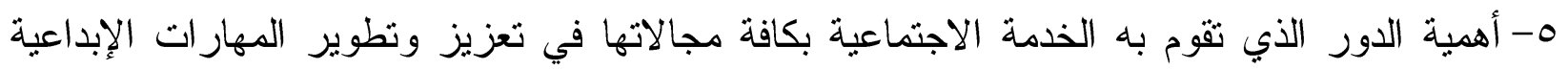
لادى طلاب الجامعة لتحقيق التميز.

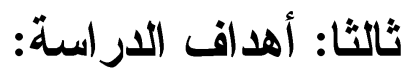
تسعى الاراسة إلى تحقيق هدف رئيسي مؤداه:

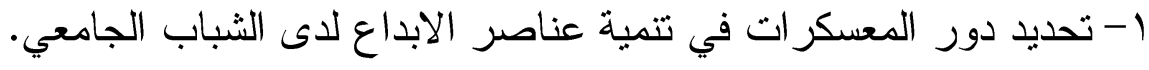

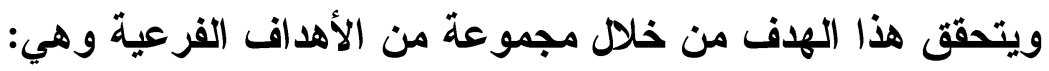
(أ) تحديد دور المعسكر ات في تحقيق الاصالة لاى الثباب الجامعي. (ب) تحديد دور المعسكرات في تحقيق الطلاقة لاى الثباب الجامعي. (ج) (جديد دور المعسكرات في تحقيق الحساسية بالمشكلات لدى الثباب الطياب الجامعي.

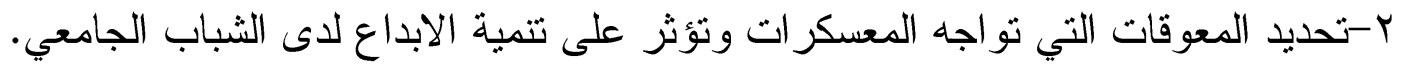
ب-تحديد مقترحات تفعيل دور المعسكرات لتتمية الابداع لاى الثبات الثباب الجامعي. رابعا: تساؤلات الدراسة. تسعى الار اسة إلى تحقيق تساؤل رئيسي مؤداه:

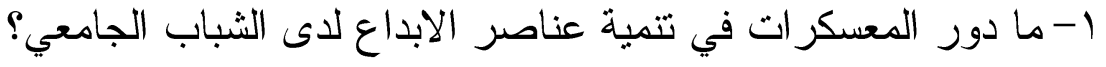
ويتم الإجابة على هذا التساؤل من خلال مجموعة من التهابل التساؤلات الفرعية وهي:

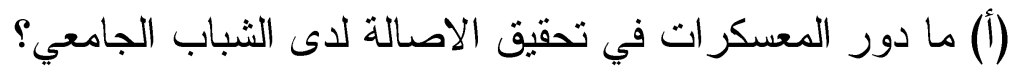

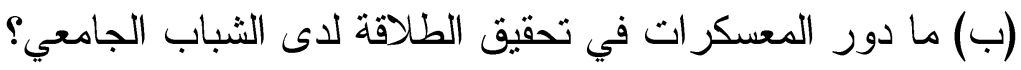

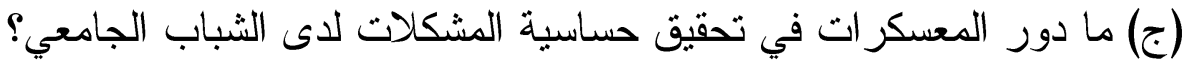

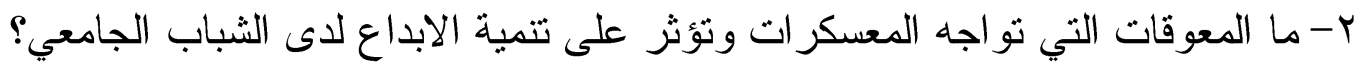




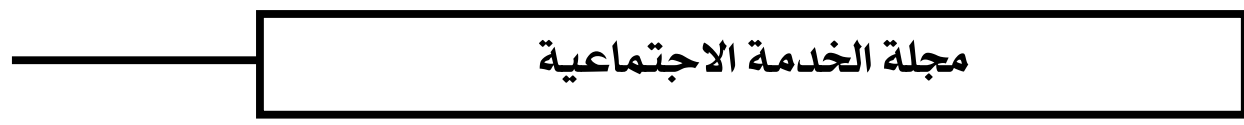

r- ما مقترحات تفعيل دور المعسكرات لتتمية الابداع لدى الثباب الجامعي؟

خامسا: مفاهيم الار اسة ومنطلقاتها (النظرية.

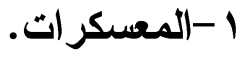

تعرف المعكرات بأنها " قطعة أرض تقام عليها خيام أو تشيد أكواخ لإقامة مجموعة من الافراد وهنالك

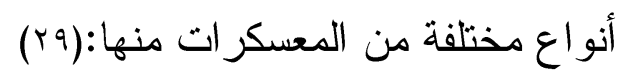
معسكرات التزويح: هي المعسكرات التي تقام في الأماكن الخلوية لتتيح للمشتركين فيها أن يحيوا حياة صحية حيث الهو اء النقي والمعيشة البسيطة والبعد عن حياة المدن المعقدة مع إثاعة روح التفاهم

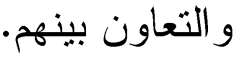

معسكرات العمل: هي معسكرات تهدف الى دفع الثباب للمساهمة في الانشاء والتعمير وتقدير العمل اليدوي مهما كان بسيطا. كما تعرف أيضا المعكرات بأنها" خبرة تعاونية ابتكارية تعليمية لحياة الجماعة في الخلاء لممارسة حياة الجماعة في بيئة طبيعية ولمدة معينة وتحت اشراف ريادة مؤهلة وتتوفر فيها خبرة تربوية تتسم بالابتكارية و الابداعية لحياة الجماعة حيث أنها تستقل المصادر الطبيعية المحيطة بموقع المعسكر • (•r) وأيضا تعرف المعسكرات بأنها "عبارة عن لقاء منظم لمجموعة من الافر اد ذات روابط الأبهاء أو مقاصد محددة

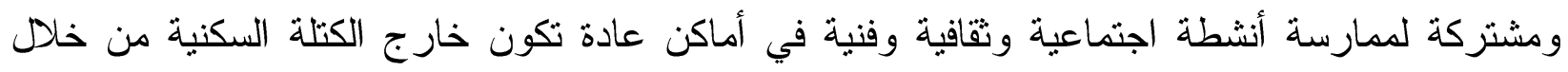
برنامج محدد سابقا ويشرف على تتفيذ المعسكر لجنة أو قيادة ذات خبرة ومهارة لتحقيق الهدف المنشود.

ويمكن تحديل مفهوم المعسكرات اجرائيا وفقا للار اسة بأنها: 1-وسيلة للتعبير تستخدم كافة الأنشطة الاجتماعية والثقافية والفنية والرياضية لتحقيق أهداف

منتو عة. ץ- يهدف الى تحقيق هدف مشترك وهو تتمبة الابداع لدى الطلاب. r- يركز على أهمية العمل الجماعي و التعاون و المشاركة بين الطلاب. ع- يشرف على المعسكرات هيكل ادارى وتتظيمي ذات خبرة وكفاءة عالية يسنطيعون توجيه الطلاب

$$
\text { و اكتشاف مو اهبهم. }
$$

و هناك العديد من الأهداف والاغراض التي تسعى اليها المعكرات التدريبية ومن أهمها:(r؟) 1- تتمية الميل الى المشاركة التعاونية مع الغير خلال البرامج و الأنشطة المختلفة بالمعسكر . ץ- مساعدة الأعضاء على تحمل المسئولية عن طريق توزيع المسؤوليات العديدة عليهُ. 


\section{لـمجلة الخدمة الاجتماعية}

ب- التدريب على القيادة والتبعية ومساعدة القائد على القيام بالدور القيادي الذي يتفق مع استعداداته

$$
\text { ومو اهبه. }
$$

ع - تتمية شخصية الأعضاء ومقابلة حاجاتهم وتتمية قدر اتهم ومهار اتهم.

0-تتيح المعسكرات الفرصة لاكتساب النمو الاجتماعي والعقلي والبدني من خلاه اكتساب مهار ات

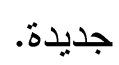

צ- تتيح المعسكر ات الفرصة لتتمية القدرة على الابتكار و الابداع.

ويتم تحقيق هذه الأهداف عن طريق مجموعة من الأشطة والبرامج منها: (rr)

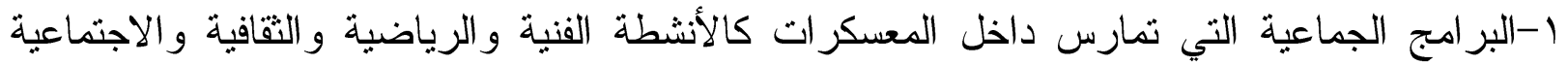

و السمر وممارسة الحياة الجماعية داخل تتظيم معين وفق اشر اف واعى.

ب-تتفيذ مشروع لخدمة البيئة كنظافة البيئة وتجميلها ومشروعات الدهانات و التشجير أو ترقيم المنازل و غيرها من المشروعات.

ب-اجر اء بحث ميداني حيث يشارك الطلاب في جمع البيانات و الاتصال بالمبحوثين واجر اء مقابلات مع المسئولين و القبادات في المجتمع ثم تفريغ البيانات وجدولتها وتحليلها.

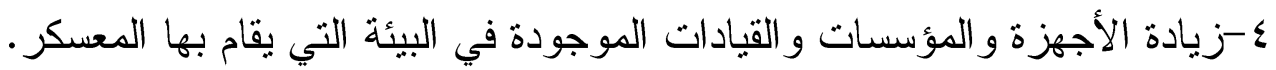

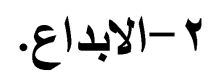

أن الابداع يشكل ضرورة ملحة ولا سيما في عصرنا الحالي، فهو يلبى حاجات انسانية للفرد وهي حاجات

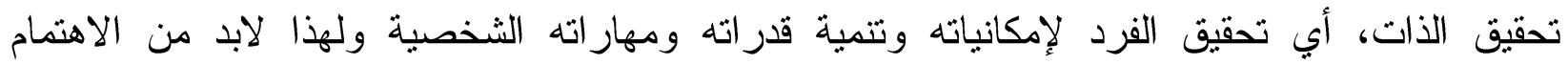

بالمبدعين لكي تظهر قدر اتهم وتتمو وحتى يتحقق ذلك لابد من توفير أساليب ووسائل للرعاية الثاملة.

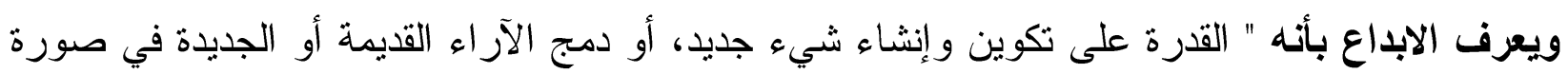

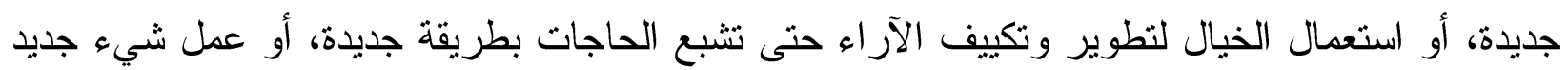

ملموس أو غير ملموس بطريقة أو بأخرى. (عَّ) كما يعرف أيضا بأنها" الوحدة المتكاملة لمجموعة العو امل الذاتية و الموضوعية التئي تقود الى تحقيق انتاج جديد و أصيل وذوي قيمة من قبل الفرد أو الجماعة". (ro)

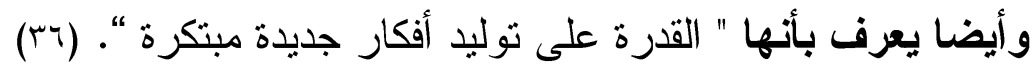
كما يمكن تعريف الابداع بأنه " هو العملية الخاصة بتوليد منتج فريد وجديد بإحداث تحول بداثل من منتج ثائم،

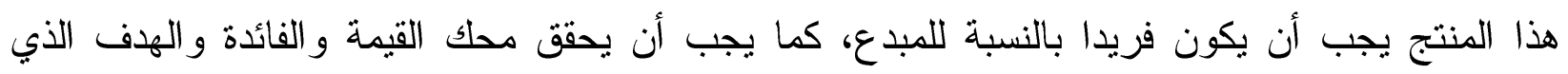

وضعه المبدع. (rv) 


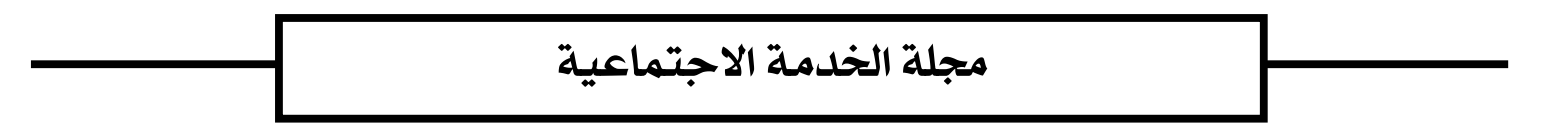

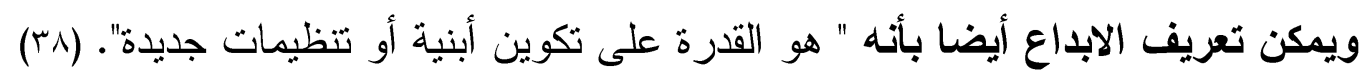

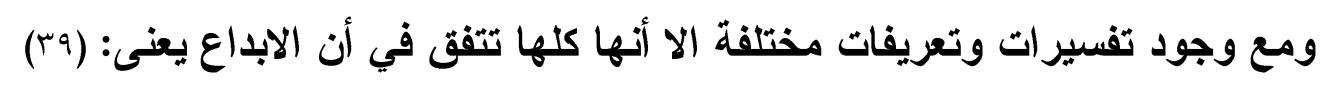
- - عملية نحقق نتائج متميزة.

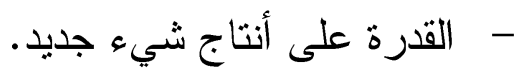
- - القدرة على تقديم الحلول المبنكرة. وبناء على ما سبق يمكن تحديد مفهوم الابداع اجر ائيا وفقا للار اسة بأنه: 1- استعداد فطري ينمى من خلال التعليم و التنريب الجامعي.

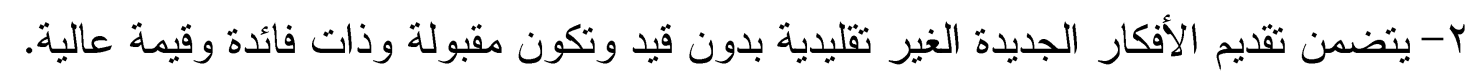

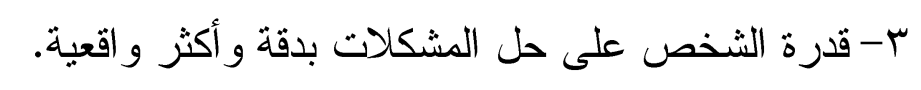

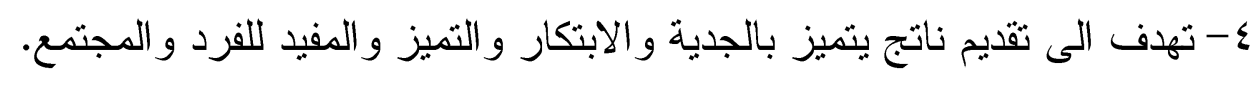
مكونات الابداع لاى الثباب الجامعي.

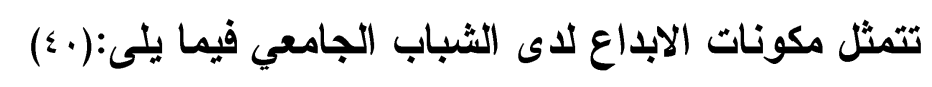

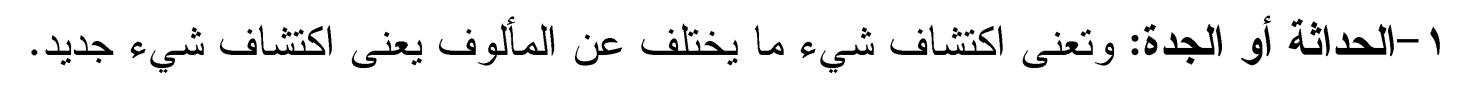

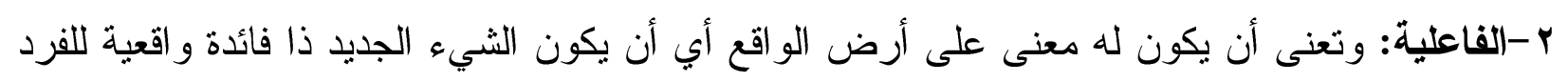

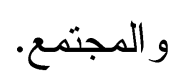
ب-الأخلاقية: وتعنى الالتز ام بالقو اعد الخلقية، وألا يستخدم الابداع في الثر. عناصر الابداع لاى الثباب الجامعي.

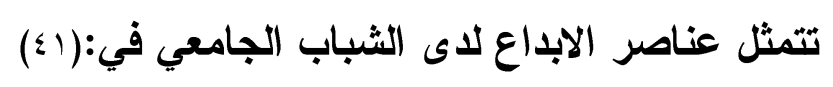

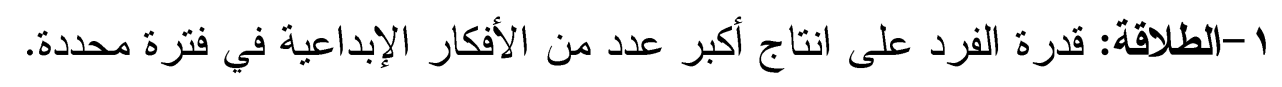

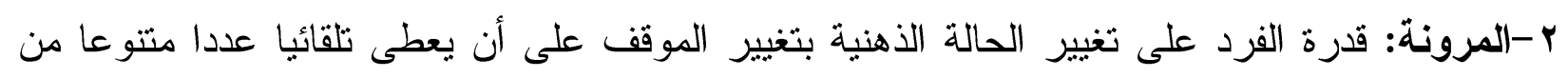

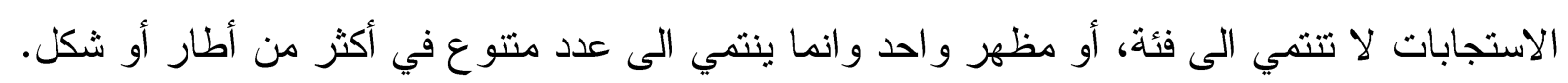

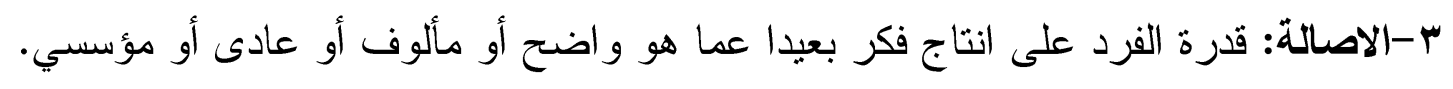

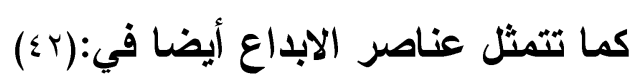

ع -الحساسية بالمشكلات: وتتمثل في قدرة الفرد على اكثثاف المشكلات المختلفة في المو اقف المختلفة

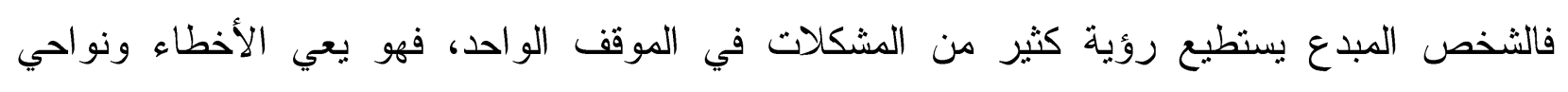
القصور ويحس بالمشكلات إحساسا مر هفا. 


\section{لـمجلة الخدمة الاجتماعية}

ه-التحليل: يقصد به انتاج إبداعي أو ابتكاري يتضمن عملية انتخاب أو اختيار وتفتيت أي عمل جديد الى وحدات بسيطة ليعاد تنظيمها.

ج-المخاطرة: يقصد به أخذ زمام المبادرة في تبنى الأفكار و الأساليب الجديدة و البحث عن حلول لها في الوقت نفسه الذي يكون فيه الفرد على استعداد لتحمل المخاطرة الناتجة عن الاعمال التي يقوم بها ولديه

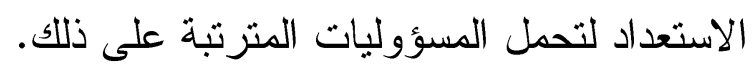
V-الخروج عن المألوف: يقصد به القدرة على التحرر من النزعة التقليدية والتطورات الثائعة والقدرة

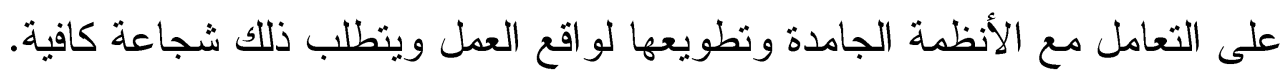

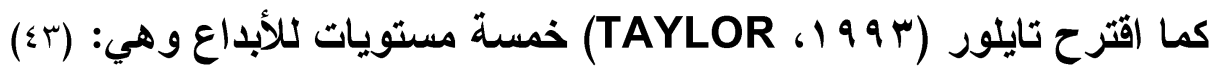

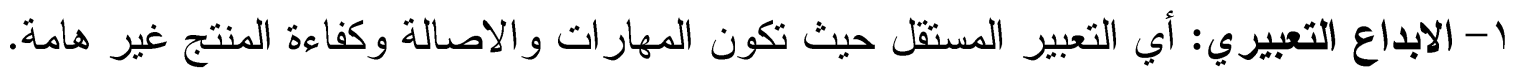
r- الابداع الإتتاجي: أبي النواتج الفنية أو العلمية حيث يوجد تطوير أساليب لإنتاج منتجات مكتملة.

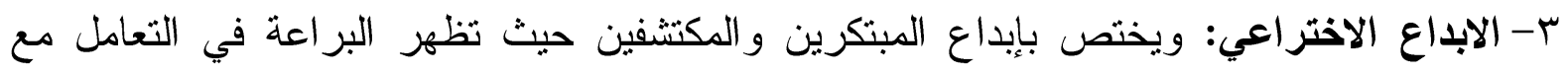
المو اد و المناهج و الأساليب. ع-الابداع الابتكاري: ويتعلق بعمليات التحسين المستمرة من خلال القيام بتعديلات تشمل مهارات تجريدية وتصورية فمثلا ابتكار نظريات جديدة في العلم أو الفن، ولكن بالاستتاد على أفكار

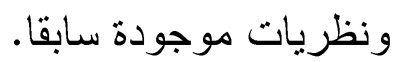
0- الابداع الأبثاقي: و هذا يتعلق بالافتز اض الجديد وقد يكون هذا في ذهن العديد من الأشخاص

$$
\text { عندما يتحدثون عن الابداع. }
$$

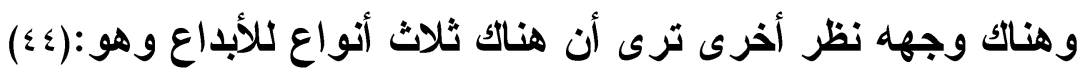
ا-الابداع التوافقي: وهو الذي ينطوي على توليد الأفكار الجديدة و المألوفة. r- الابداع الاستكشافي: وهو الذي ينطوي على توليد أفكار جديدة من قبل استكثاف المفاهيم بطريقة منظمة. ب- الابداع التحولي: وهو الذي ينطوي على تحويل بعض أبعاد الهياكل الى هياكل جديدة يمكن أن تولد. أساليب تنمية الابداع لاى الثباب الجامعي: 1-العصف الأهني: وتعنى استخدام العقل في التصدي للمشكلة - فالعقل يعصف بالمشكلة-ويفحصها

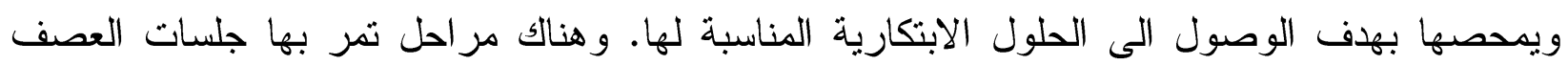
الذهني تتمنل في:(0) 


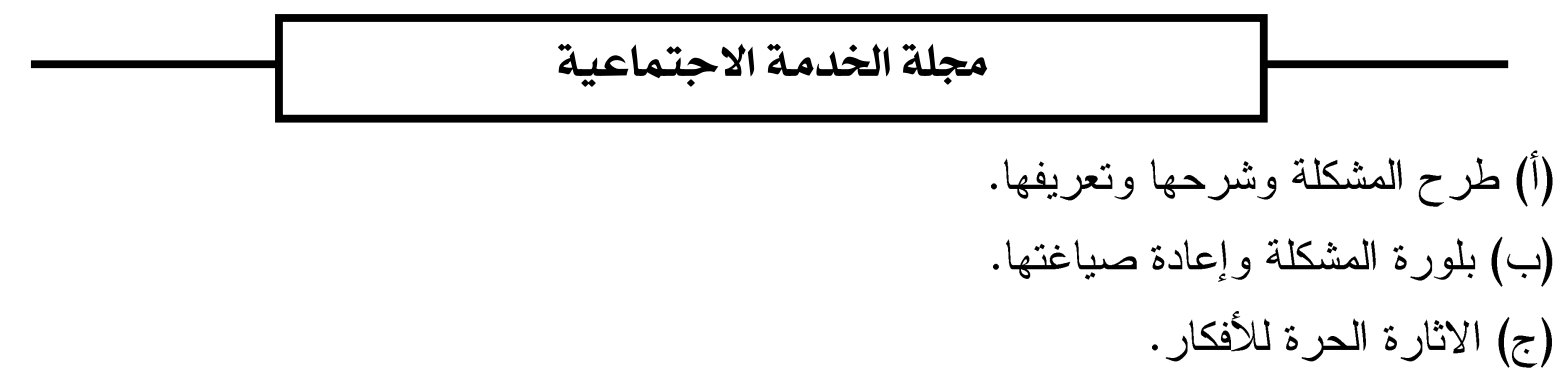

(د) تقييم الأفكار التي تم التوصل اليها في التهار المر احل السابقة. (ه) الاعداد لوضع الأفكار موضع التتفيذ

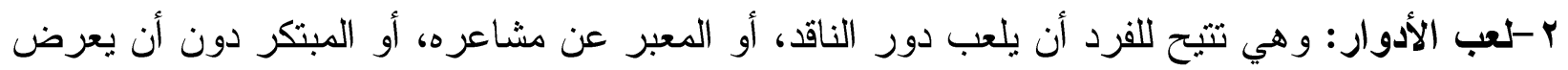

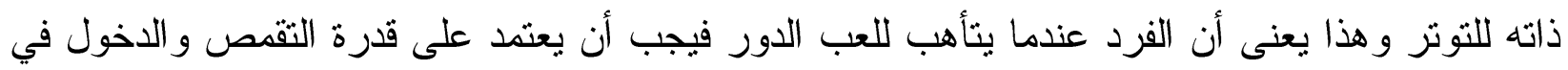

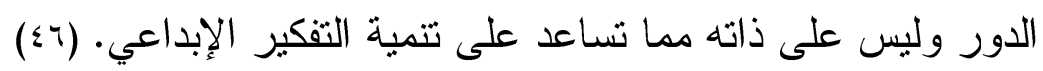

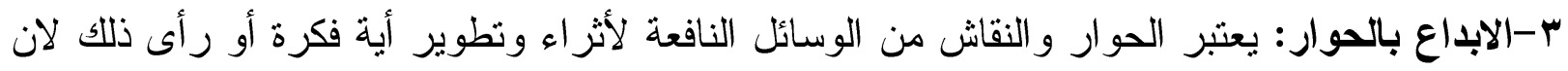

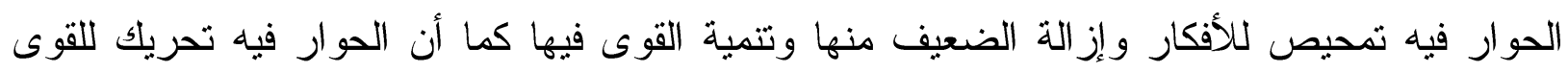

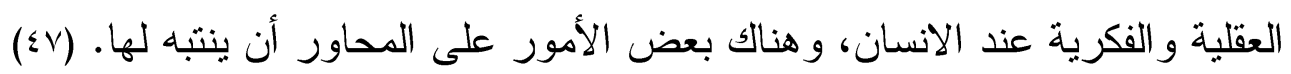

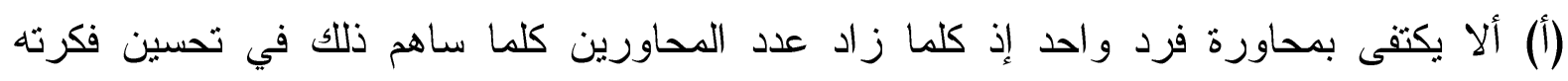

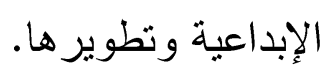

$$
\begin{aligned}
& \text { (ب) أن يختار الزمان و الدكان و الظروف المناسب للحوار و النقاش. }
\end{aligned}
$$

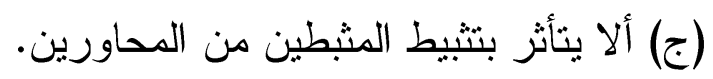

ع-أسلوب الجماعات الاسمية: يعتبر هذا الأسلوب محاولة لاتباع الدذخل العلمي لنتجيع الافراد على العين

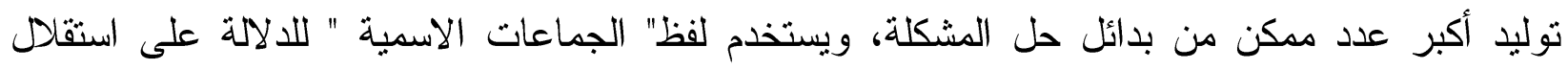

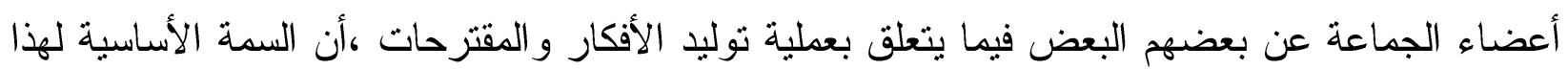

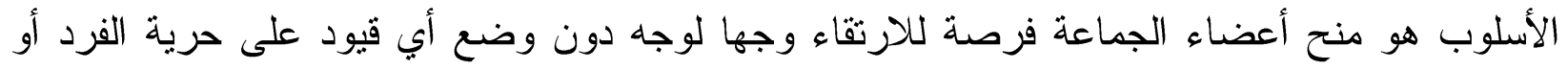

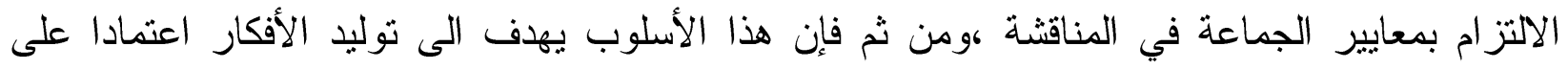

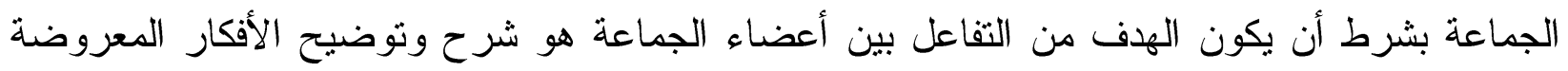

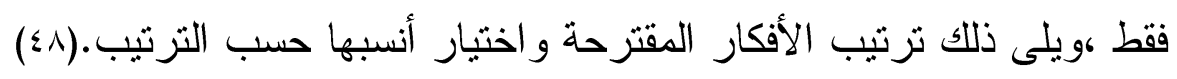
خصائص الابداع لاى الثباب الجامعي:

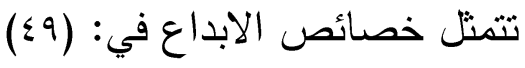
1- القدرة على اكتثاف علاقات جديدة.

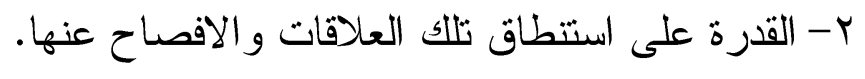
ب- الربط بين العلاقات الجديدة وبين العلاقات القديمة التي سبق لغيره اكتثافها. 


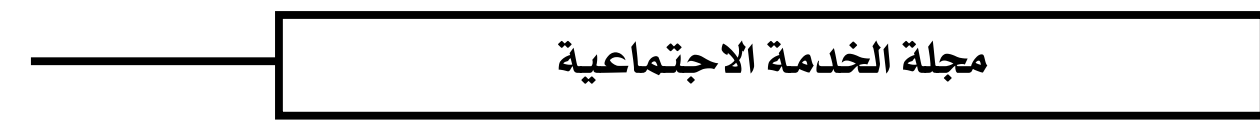

ع-توظيف العلاقات الجديدة لتحقيق أهداف معينة.

0- الاحجام عن الاخذ عن الاخرين إلا بالقدر الذي يخدم ويحقق الإبداعية لديه. צ- الابداع علم نظري تجريبي ليس نهائي، فبعض ما هو صحيح اليوم قد يلغى غدا و العكس صحيح. V يوجد الابداع عند كل الناس بدرجات متفاوتة ومجالات مختلفة.

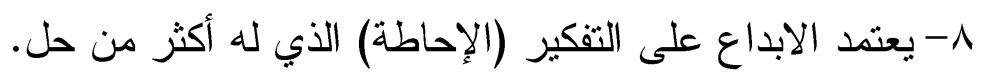
9- قادر على النظر الى الأمور من زوائم الائ مختلفة. • أمابل للانتقال و النطبيق.

11-حساس للمشكلات أي قادر على إيجاد حلول مختلفة لها. r ا-قادر على ملاحظة التناقضات و النو اقص في البيئة. با ا-المبدع لا يفكر في حل جديد فحسب بل يدرك مشكلات جديدة وينظر الى المألوف و الشائع من خلال منظور جديد.

معوقات الابداع لاى الثباب الجامعي:

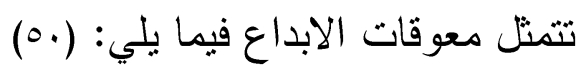

1- العقبات الثخصية: وهي التي تتعلق بشخصية الطالب وتؤثر في طريقة تفكيره وسلوكه منل:

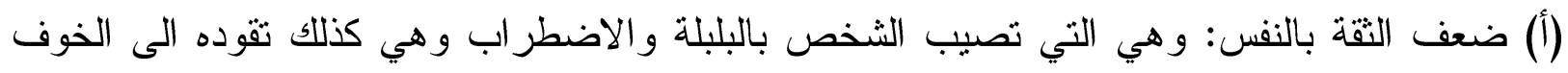
من الإخفاق وتجنب المخاطرة و المو اقف غير المأمونة. (ب)|لميل للمجاراة: وهذا يعيق استخدام المدخلات الحسية، ويحد من احتمالات التخيل و التوقع وبالتالي يضع الثخص حدودا لتفكيره الإبداعي. ولئ. (ج)الحماس الدفرط: تؤدى الرغبة القوية في النجاح و الحماس الزائد لتحقيق الإنجازات الى استعجال النتائج قبل نضوج الحالة وربما القفز الى مرحلة متأخرة في العملية الإبداعية.

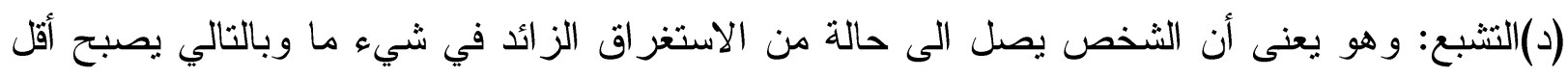
و عيا و ادر اكا بحيثيات الوضع الر اهن ويفتقد كذلك الدقة في المشاهدات. (ه)التفكير النمطي: حيث يصاب تفكير الطالب بالنمطية ويصبح شاكلة واحدة أو وتيرة واحدة فهو يفتقد الى المرونة و القدرة على التغيير • r-العقبات الظرفية: ويقصد بها تلك العقبات التي تحيط بالموقف كالجوانب الاجتماعية و الثقافية السائدة وتؤثر سلبا على عملية الابداع وعلى ظهور وتتمية المهار ات الإبداعية لاى الافر اد ومن أهمها: 


\section{لمـلة الخدمة الاجتماعية}

(أ) مقاومة التغيير: وهو أن بعض الناس يميل الى مقاومة التغيير ويقف ضد الأفكار الجديدة ويحاربها بالعديد من الوسائل و الأساليب.

(ب)عدم التوازن بين التتافس و التعاون: هنالك حاجة للمزج بين روح التنافس وروح التعاون لكل من الفرد و الجماعة لتحقيق إنجاز ات قيمة ويعتبر عدم توفير هذا التوازن سببا في ضعف التهن الابداع.

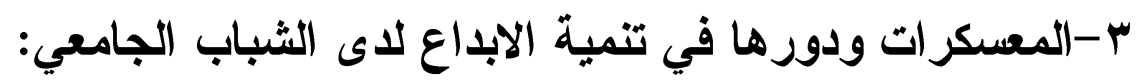
يمكن أن تساهم المعكرات في تنمية الابداع لدى الثباب الجامعي وذلك من خلال اسهامها في تحقيق كثير من الفوائد من بينها: (01)

1- ان تدريس التفكير يكسب الطلاب رضا وسعادة ويزيد من دافعيته للتعليم و العمل.

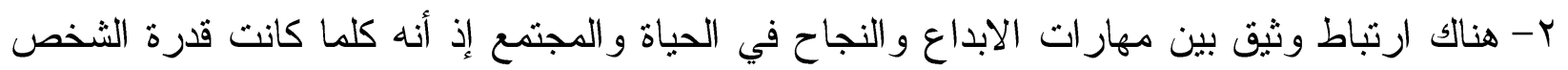

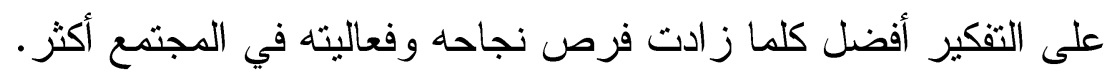

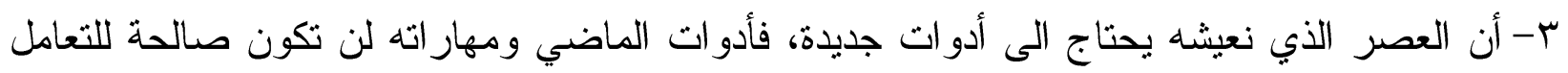

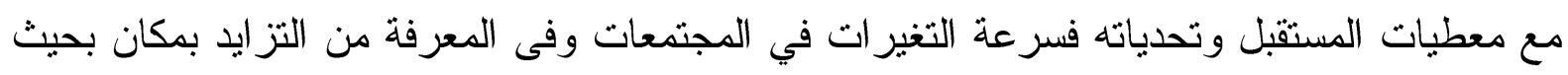

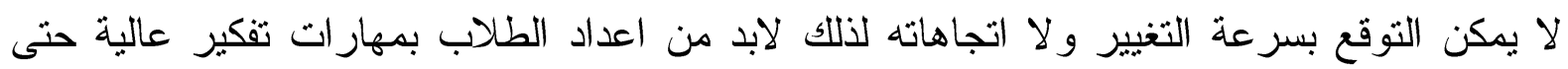
يسنطيعوا التعامل مع المستقبل بظروفه المختلفة. ع- إن التفكير الجيد يساهم في إيجاد مواطن صالح، إذ أن التفكير الجيد يساعد على التفريق بين الصواب

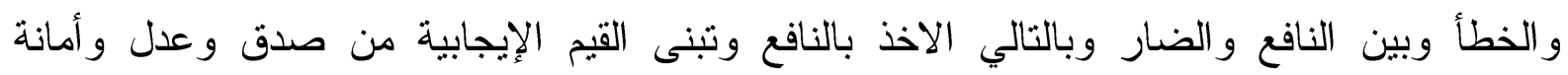
و احتر ام وتجنب القيم السلبية.

0- إن التفكير يساعد الانسان على فهم وممارسة الديمقراطية لان الديمقراطية ليست شعار وانما قيمة

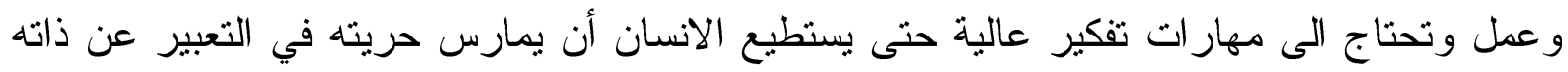
و أفكاره بشكل إيجابي وأن يتعامل مع حريات الاخرين و أفكار هم بشكل إيجابي أيضا.

؟- إن تدريس التفكير ينتج لنا طلاب دائمي التعلم يمتلكون أدوات التعلم الذاتي ويمتلكون الدافعية الذاتية للبحث عن المعرفة و اكتسابها وينقلون من كونهم طلاب ايجابيين.

كما أن هناك عدة مقومات علمية تمهر للاراسة الإيجابية للمعكرات ودورها في في تنمية الجابين الابداع وهي:

(أ) الابداع ظاهرة مركبة: ولكنه قابل للفهم و الدراسة، فمنذ .ع عام مضت أخضع الابداع للار اسة و البحث، ولذلك ظهرت نظريات متعددة تساعد في فهمه وتتظيمه. 


\section{لـمرجلة الخدمة الاجتماعية}

(ب) الابداع ظاهرة إنسانية طبيعة: وليس قاصر ا على ذوي الموهبة وهذا معناه أن الابداع موجودا

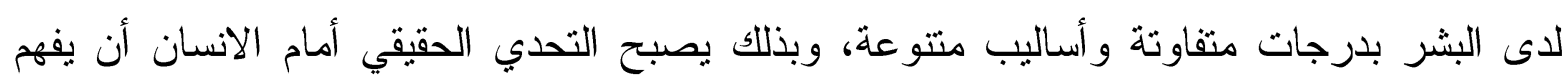
ويوظف ما لديه من إمكانيات إبداعية.

(ج) الابداع ظاهرة صحية: حيث أن فهم الانسان لما لديه من ابداع وكيفية نوظيفه يساعد على التخفيف من التوتز ويساعده على الحياة الصحية المنتجة. (د) الابداع ممتع: فحين يتعرف الانسان على ما لديه من ابداع ويستطيع توظيفه فسوف يعود عليه ذلك بالرضا و الاتجاز و الاثارة.

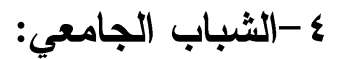
يعرف الثباب "بأنه الفرد الذي يتزاوح سنه بين الثامنة عشر و الرابعة والعشرين، وتعتبر هذه المرحلة مرحلة انتقالية الى الرجولة ويتخطى الفرد مراحل التوجيه والتوعية ويكون أكثر تحررا. (بهم) كما تعرف أيضا "بأنها تلك المرحلة العمرية التي تمتد ابتداء من مرحلة الطفولة الى ما قبل الرشد. (؛ـه) كما أن هناك اتجاه يحدد مرحلة الثباب بمقياس سلوكي أي اعتبار هذه المرحلة تشكل مجموعة من

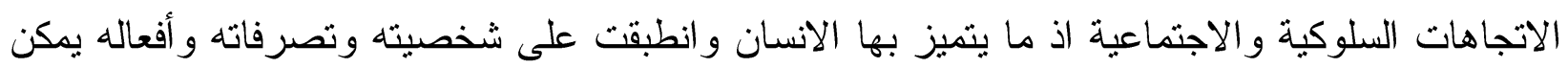
اعتباره شابا. (00)

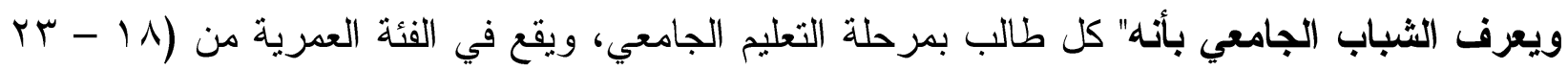

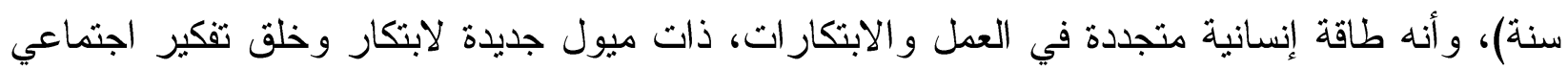
حيوي. (10) كما تعرف أيضا الثباب الجامعي" بأنه الفترة من الحياة التي ينضم فيها الثباب الى الجامعة ويكون عمره من VIV-10 عاما وتتسم بالقوة والنشاط والقدرة على العمل والانجاز والابداع وتقبل الأفكار الجديدة وتتميز بشدة الحساسية للأوضاع الجديدة بروح المغامرة و التصدي للو اقع ومشكلاته وتعتبر مرحلة اختبار وتخطيط للمستقبل الا أنها تفتقر للخبرة و التجربة وتحتاج هذه الفترة الى الاعداد و التأهيل لمو اجهة الحياة.

وبناء على ما سبق يمكن تحديد مفهوم الثباب الجامعي اجرائيا وفقا للار اسة بأنه:

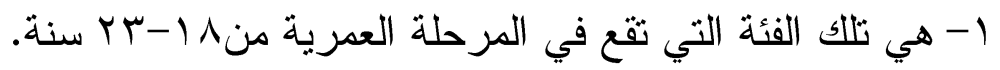
r- طلاب لايهم الرغبة للمشاركة في معسكر ات اعداد القادة. ب- مرحلة عمرية تتسم بالحيوية و النشاط. ع-تتميز هذه المرحلة بالإنجاز و الابداع. 


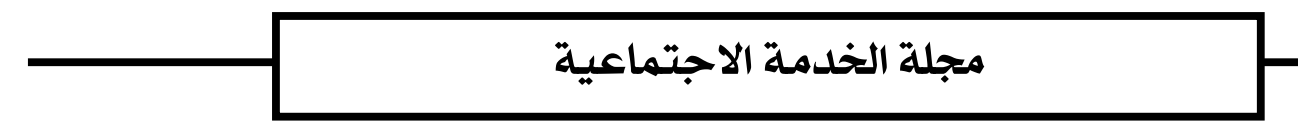

سادسا: الاجر اءات المنهجية للاراسة:

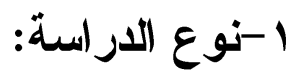

تنتمي الدراسة الحالية إلى نمط الدراسات الوصفية التحليلية وهي تعتبر من أنسب الأساليب ملائمة لطبيعة الموضوع التي تهتم بتحديد ووصف وتحليل دور المعسكر ات في تنمية الابداع لاى الثباب الجامعي.

ب-المنهج المستخدم: اعتمدت الباحثة على استخدام المنهج العلمي الكمي لجمع البيانات وتحليلها، والكيفي لاستخلاص النتائج

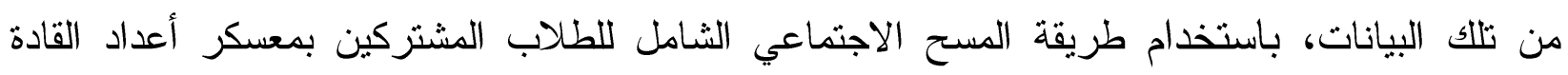

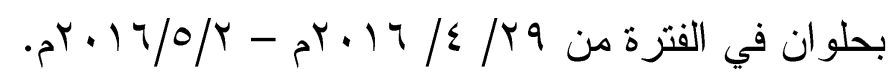

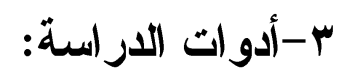

- استمارة قياس: (مطبق على الطلاب المشتركين بمعسكر اعداد القادة بحوان). لتحديد دور

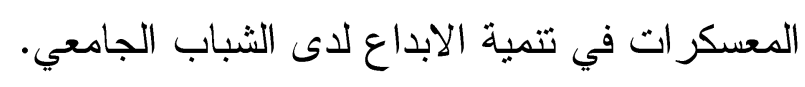
وقد قامت الباحثة بالخطوات الآتية عند اعداد استمارة القياس:

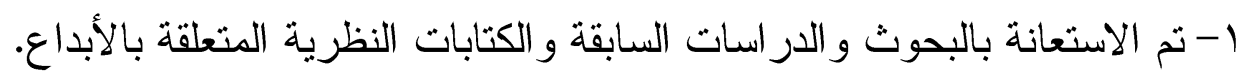

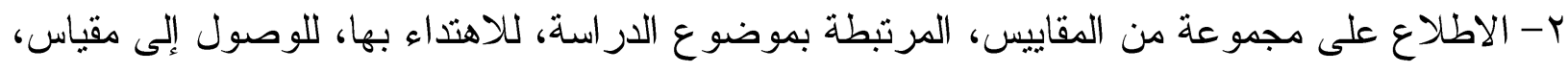
يلاءم أهداف الدراسة. r-تم تحديد أبعاد المقياس واضعة في الاعتبار ارتباط كل بعد بموضوع المقياس، وأن يتصف البعد بالوضوح و التحديد.

وسوف يطبق المقياس على الطلاب المشتركين بمعكر اعداد القادة بحوان، ويتضمن المقياس

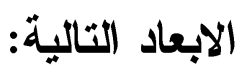
البعد الاول: تحديد دور المعكرات في تنمية عناصر الإبداع لاى الثباب الجامعي: ويقصد به تحديد

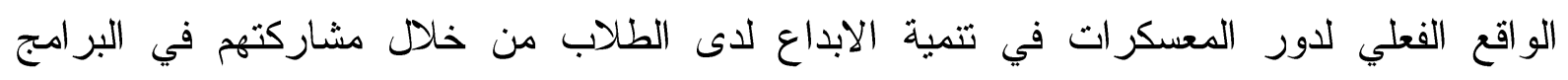
و الانشطة المعدة بالمعسكر.

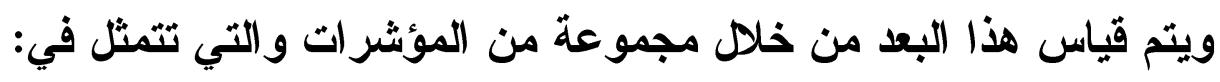

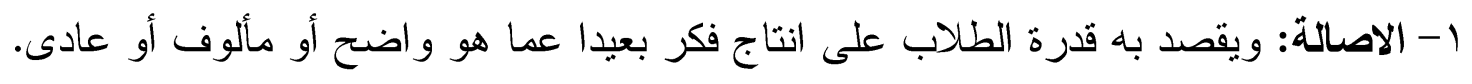
r- الطلاقة: ويقصد به قدرة الطلاب على انتاج عدد كبير من الأفكار اللفظية في فترة محددة. 


\section{口ـمجلة الخدمة الاجتماعية}

ب-الحساسية بالمشكلات: وتتمثل في قدرة الطلاب على اكتثاف المشكلات المختلفة في المو اقف المختلفة البعد الثاني: تحديد المعوقات التي تواجه المعسكرات وتؤثز على تتمية الابداع لدى الثباب الجامعي: ويقصد به الصعوبات التي تو اجه الطلاب وتؤثر على قدر اتهم الفكرية و الابداعية. ويتم قياس هذا البعد من خلا مجموعة من المؤشرات واتل التي تثمثل في:

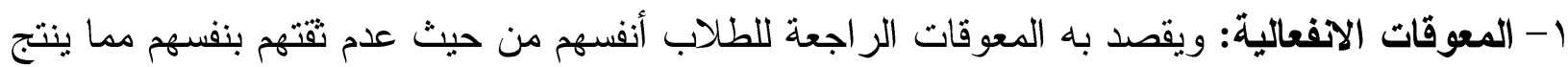
عنه الخوف الدائم من المخاطرة بكل ما هو جديد. ץ- المعوقات الثقافية: ويقصد به الظروف السياسية والاجتماعية والاقتصادية التي تمر به المجتمع ويكون ذات تأثير سلبي على الطلاب في أخر اج قدر اتهم ومهار اتهم الإبداعية.

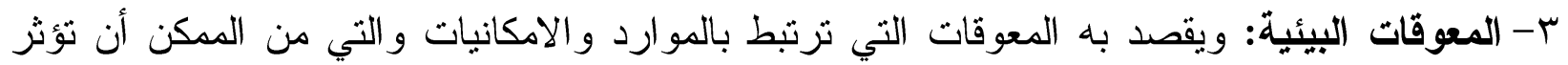
على تتمية التفكير الإبداعي للطلاب ع - المعوقات الفكرية: ويقصد به التحيز الفكري و التقليدية في توليد الأفكار في المو اقف المختلفة. ه- المعوقات التعبيرية: و التي يقصد به عدم اتاحة الفرصة للطلاب للتعبير عن أراههم بحرية مما يؤثر على قدر اتهم العقلية في حل المشكلات. البعد الثالث: تحديد المقترحات لتفعيل دور المعسكرات في تتمية الابداع لدى الثباب الجامعي. ع-قامت الباحثة بعد تحديد أبعاد المقياس بصياغة مجموعة من العبار ات التي تتشىى مع كل بعد على حدة. حيث كانت عبار ات المقياس (V9) عبارة. موزعة كالتالي: - بعد دور المعسكر ات في تنمية عناصر الابداع (؟ ؟) عبارة

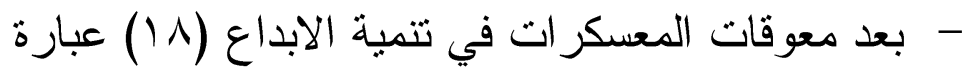

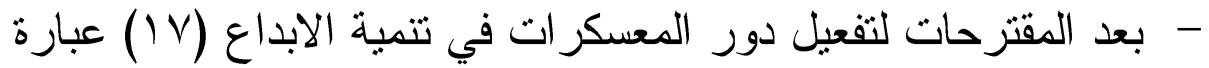
ه-تصديد أوزان عبارات المقياس: اعتمد هذا المقياس على صباغة الاستجابة، وفق التـدرج الثلاثيـي

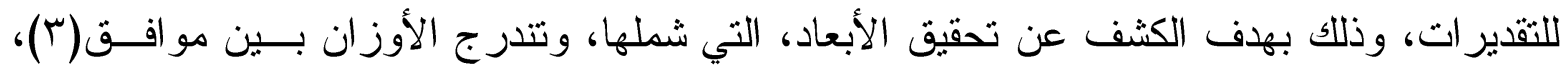

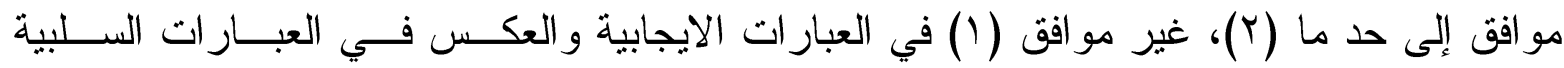

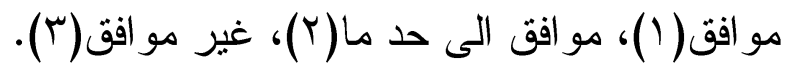
צ-تحكيم المقيــاس: قامت الباحثة بعرض أداة الدر اسة في صورتها المبائية على عدئ عدد من أعضاء هيئة

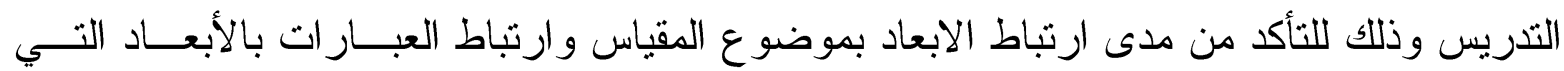

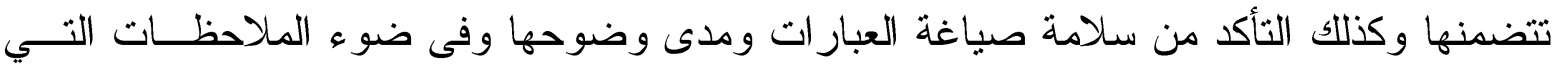




\section{لـمجلة الخدمة الاجتماعية}

أنتهى اليها المحكمين قامت الباحثة باستبعاد العبار ات التي تحتاج الى إعادة صياغة وأيضـا إضــافة بعض العبار ات التي اتفق عليها المحكمين. V-ثبات الأداة: ثم التأكد من ثبات الأداة عن طريق إعادة الاختبار بالتطبيق على عينة قوامها( ( ) من الطلاب المشتركين بمعسكر أعداد القادة وقد تم رصد هذه العينة واستجاباتهم، ثم قامت الباحثة بإعادة الاختبار ثم تم تطبيق نفس الأداة على نفس الطلاب وذلك بعد(0 1) خمسة عشر يوما من الاختبــار الأول، وتث حساب ارتباط سيبرمان بين نتائج الاختبار الأول والاختبار الثاني وذلك لتحديد ثبات أداة

$$
\text { ع جمع البيانات حيث وجد معامل ثبات الأداة (7 } 9 \text { ، \%). }
$$

أ- المجال المكاني: تحدد المجال المكاني للار اسة في مقر معسكر أعداد القادة بحلوان. ب-المجال البشرى: تم تطبيق الدراسة بالحصر الشامل على الطلاب المشتركين بمعسكر أعداد القادة

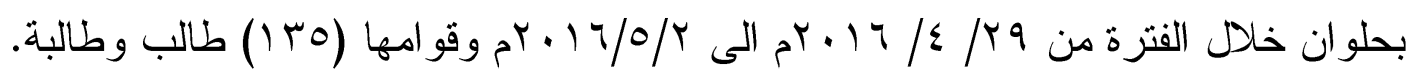




\begin{tabular}{|c|c|c|c|c|}
\hline & \multicolumn{2}{|c|}{ ــمجلة الخدمة الاجتماعية } & t & \\
\hline \multicolumn{5}{|c|}{ 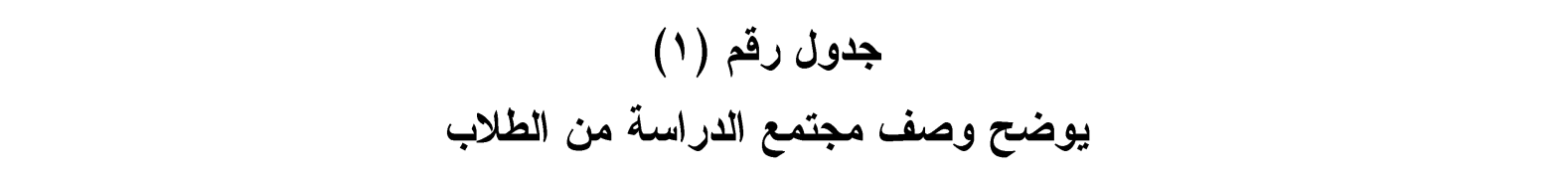 } \\
\hline النسبة المئوية & التكرار & الاستجابة & الصفة & p \\
\hline \%79.7r & $9 \leqslant$ & ذكر & \multirow{2}{*}{ النوع } & \multirow[t]{2}{*}{1} \\
\hline$\% r \cdot . r v$ & $\varepsilon 1$ & أنثى & & \\
\hline$\%$ ro.9r & ro & من 11-أقل من ·r سنة & \multirow[t]{3}{*}{ 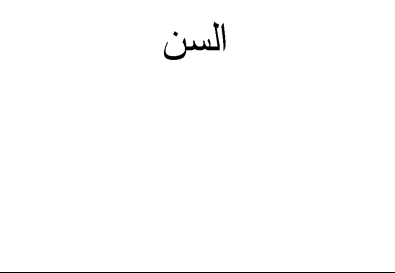 } & \multirow[t]{3}{*}{$r$} \\
\hline$\% 00.00$ & vo & من ·r-أقل من r r سنة & & \\
\hline$\% \backslash 1.01$ & ro & من r سنة فأكثر & & \\
\hline$\%$ Y0.11 & $r \varepsilon$ & ال الأولى & \multirow[t]{4}{*}{ الفرقة } & \multirow[t]{4}{*}{$r$} \\
\hline \% \%ч.74 & 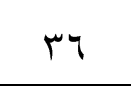 & الثانية & & \\
\hline$\%$ IV.VV & $r \varepsilon$ & الثالثة - الثة & & \\
\hline$\% r \cdot . r V$ & $\varepsilon$ & 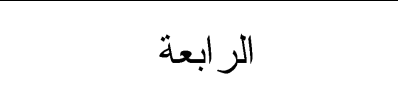 & & \\
\hline 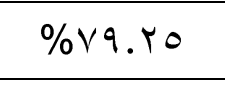 & $1 \cdot V$ & نعم & \multirow{2}{*}{ هل تشارك في الأنشطة } & \multirow[t]{2}{*}{$\varepsilon$} \\
\hline$\% r \cdot . v \varepsilon$ & ru & $\gamma$ & & \\
\hline$\% \backslash 1.01$ & ro & مرة و احدة & \multirow{3}{*}{ 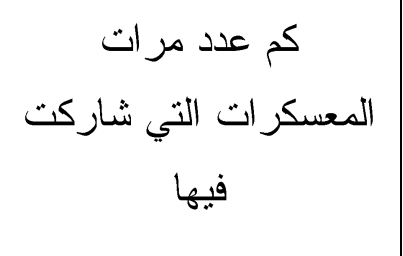 } & \multirow[t]{3}{*}{0} \\
\hline$\% \leqslant 0.9 r$ & 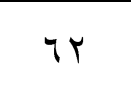 & مرنان & & \\
\hline$\%+0.00$ & $\varepsilon \wedge$ & ثلاث مرات & & \\
\hline
\end{tabular}

يتضح من الجدول رقم(1) أن الغالبية العظمى من الثباب الجامعي المشتركين بمعسكر اعداد القادة من

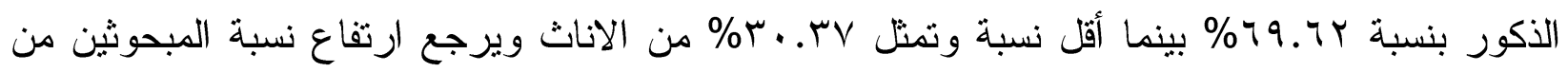
الذكور على نسبة مشاركة الاناث الى شعور بعض الأهالي بالخوف على بناتهن في ظل الظروف الحالية

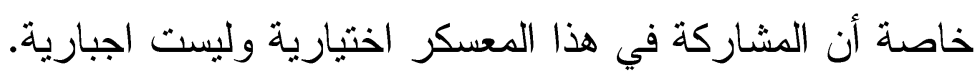




\section{口ـمجلة الخدمة الاجتماعية}

كما يبين الجدول و الذي يوضح الفئات العمرية أن النسبة الأكبر من مجتمع الدر اســـة تمثـل نســبة

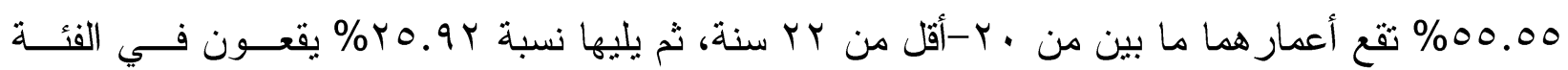

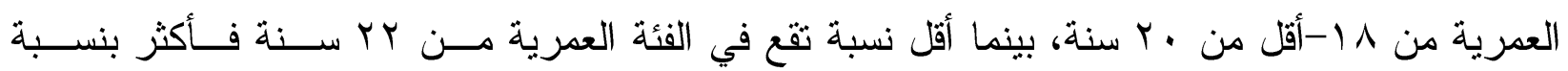

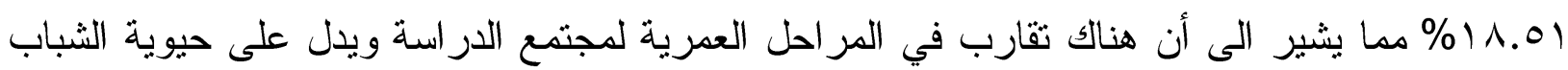
لان هذه المرحلة تعتبر مرحلة الانطلاق و الحرية.

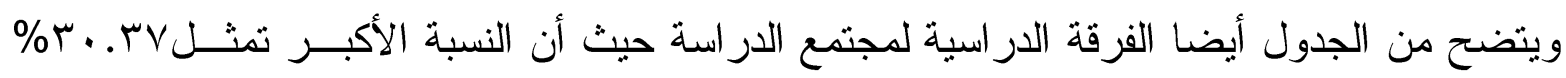

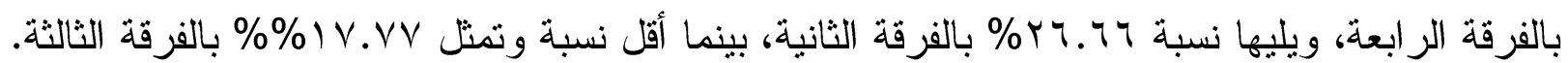

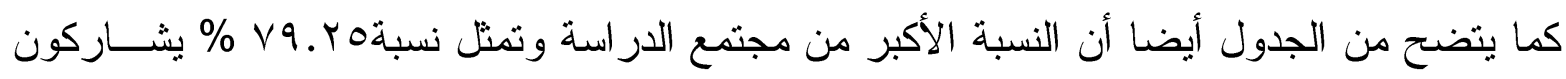

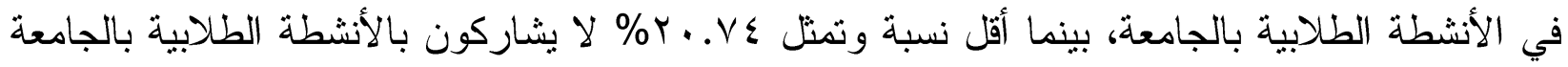

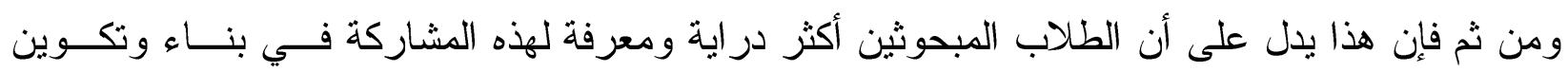
شخصياتهم.

ويوضح الجدول كذلك عدد مرات مشاركة الطلاب بمعسكرات أعداد القادة حيث أن النسبة الأكبر

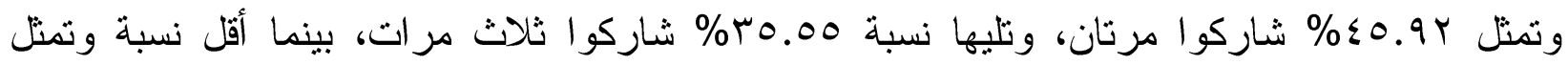

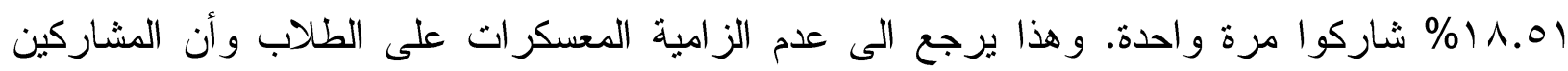

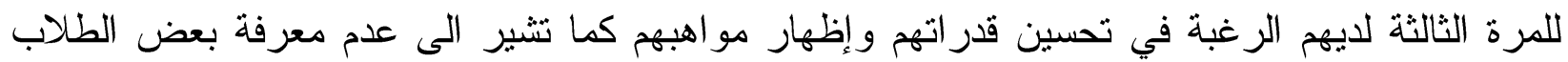
بأهمية هذه المعسكر ات.

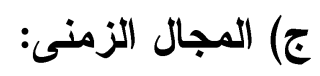

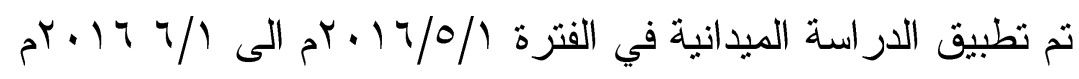
سابعا: نتائج الار اسة وتفسيرها: 1- النتائج المرتبطة بالإجابة على التساؤل الرئيس الأول ومؤداه: ما دور المعسكرات في تتمية عناصــر

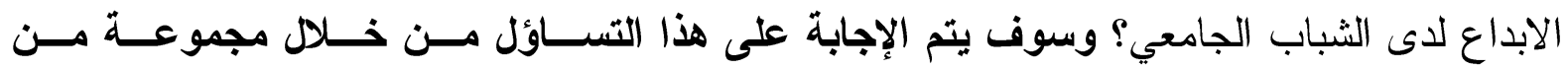

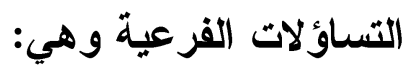

(أ)|النتائج المرتبطة بالإجابة على التساؤل الفرعي الأول للاراسة ومؤداه: ما دور المعسكرات فــي تنمية الاصالة لاى الثباب الجامعي؟ بالهابه 


\section{口مجلة الخدمة الاجتماعية}

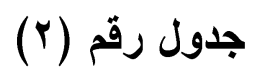

دور المعكرات في تنمية الاصاية لاى الثباب الجامعي ن=هـ

\begin{tabular}{|c|c|c|c|c|c|c|c|c|c|c|c|}
\hline \multirow{3}{*}{ 牙 } & \multirow{3}{*}{ التسبة } & \multirow{3}{*}{ |المرجوسط } & \multirow{3}{*}{ 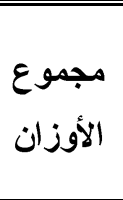 } & \multicolumn{6}{|c|}{ دور المعسكرات في تنمية الاصالة لاى الثباب الجامعي } & \multirow{3}{*}{ العبارة } & \\
\hline & & & & \multicolumn{2}{|c|}{ غير موافق } & \multicolumn{2}{|c|}{ موافق إلى حد ما } & \multicolumn{2}{|c|}{ موافق } & & \\
\hline & & & & $\%$ & s & $\%$ & ك5 & $\%$ & s & & \\
\hline$\varepsilon$ & $\% \wedge 1.9 \vee$ & r. $\leqslant 0$ & rut & $\% 11.11$ & 10 & $\%$ \%..人o & $\varepsilon r$ & $\% \circ V . . r$ & $V Y$ & |لالاعشطني المعسكر على أنجاز & 1 \\
\hline 7 & $\% \wedge 1 .\{\Lambda$ & r. $\leqslant \leqslant$ & . & $\% 11.11$ & 10 & \% \% & $\leqslant 0$ & $\% 00.00$ & vo & |على التعبير عن رأيبي بحرية في تمية قدرتي & $r$ \\
\hline 0 & $\% \wedge I . V Y$ & r. $\leqslant 0$ & וTr & $\% 1 Y .09$ & IV & $\%$ \%..7r & $\varepsilon$. & \%ov.V & $\vee \wedge$ & |مهار اتي القيادية المعسكر في تتمية & $r$ \\
\hline V & $\% \wedge . . Y \leqslant$ & Y.乏. & rro & $\% 11.10$ & 17 & $\%$ \%.00 & $\varepsilon \wedge$ & $\% 0 r .09$ & $V_{1}$ & |علمني المعسكر أساليب جديدة & $\varepsilon$ \\
\hline 9 & $\% \vee 9 . .1$ & r.r. & rr. & $\% \backslash \leq . \wedge \mid$ & $r$. & אז.דr\%\% & $\leqslant 0$ & $\% 01.10$ & $v$. & | أهدافي و الإصني المعسكر على تحديد & $\circ$ \\
\hline r & $\% \vee 1.11$ & $r .1 T$ & $r \wedge \Lambda$ & $\% \backslash \wedge .01$ & ro & $\% \leq 9.74$ & $T V$ & $\%$ \%..人० & $\varepsilon r$ & |علمني المعسكر الابتعاد عن & 4 \\
\hline$\wedge$ & $\% \vee 9.0$. & r.r人 & MrY & $\% \backslash \leq \ldots V$ & 19 & אז.Tr\% & $\leqslant 0$ & $\%$ or.o9 & $v_{1}$ & | أسلواعدني المعسكر على استخدام & v \\
\hline$y$ & $\% \wedge \backslash .\{\wedge$ & r. $\varepsilon \leqslant$ & . & $\% 11.11$ & 10 & שr.זr\% & $\leqslant 0$ & $\% 00.00$ & vo & 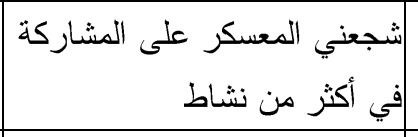 & $\wedge$ \\
\hline$r$ & $\% \wedge r . \leqslant Y$ & $Y . \leqslant V$ & ש & $\% 1 \cdot . r V$ & $1 \leq$ & $\%$ I.A० & $\varepsilon r$ & OV.VV\% & $\vee \wedge$ & |فسكاري في حالة اثبات عدم المسكر على تغيير & 9 \\
\hline 1 & $\% \wedge \leq .19$ & r.or & $r \leq 1$ & $\% 9.74$ & Ir & $\%$ \%^.1 $\leq$ & rᄉ & \%Tr.rY & $\wedge \varepsilon$ & |اتاح لي المعسكر فرص التعلم & 1. \\
\hline ir & 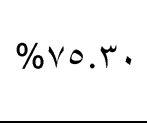 & r. ro & r.o & אז."זו \% & 11 & $\% \vee \leq . \varepsilon$. & $7 \varepsilon$ & \%rq.૫० & r & 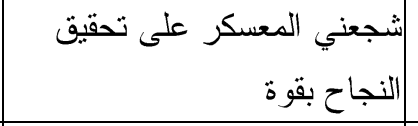 & 11 \\
\hline ir & 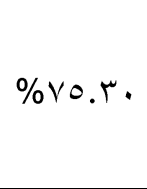 & r. ro & r.o & $\% 1 Y .09$ & IV & $\% \wedge \leq . \wedge \wedge$ & 77 & $\%$ \%..०1 & or & 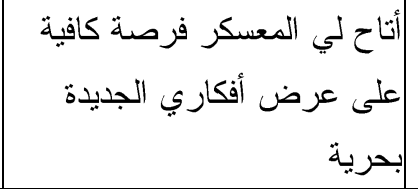 & ir \\
\hline r & $\% \wedge r . \leqslant 0$ & r.o. & ma &.$\% 9.7 r$ & 14 & $\% r \cdot . r V$ & $\varepsilon$ & $\% 4$. & $\Lambda$ & |ثجعني المعسكر على تتفيذ & $M$ \\
\hline
\end{tabular}




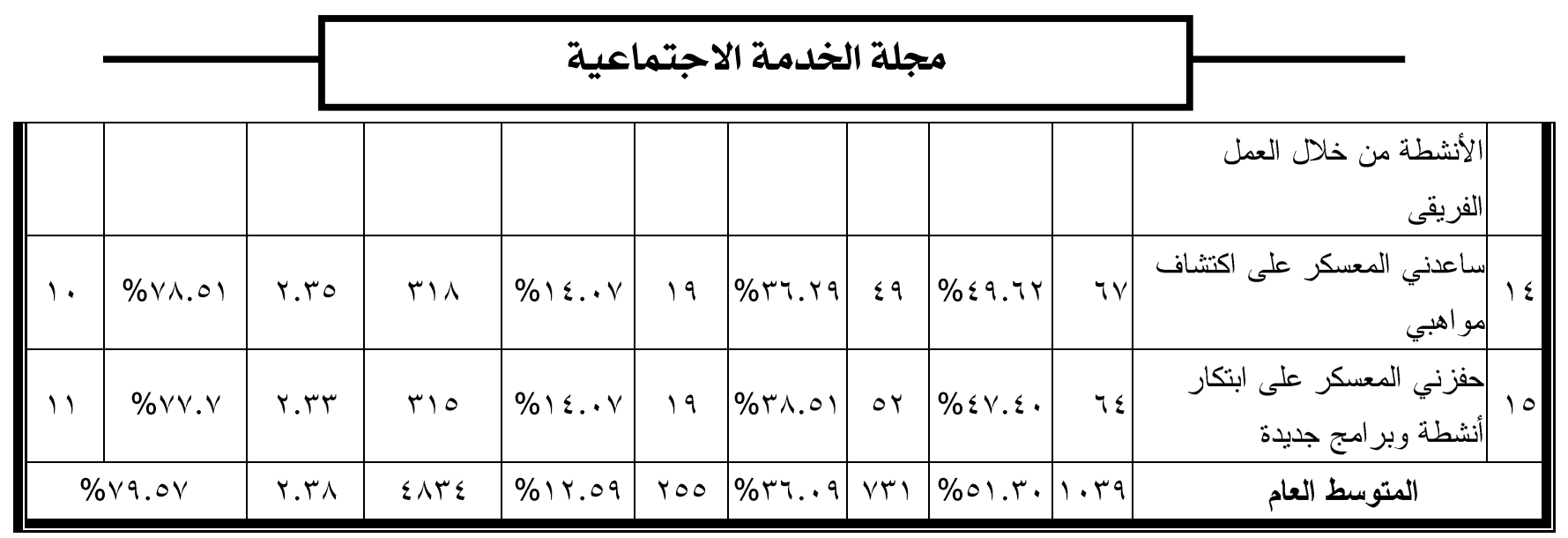

يتضح من الجدول رقم (Y) أن دور المعكرات في تنمية الاصالة لدى الثباب الجامعي مرتفع، حيـث

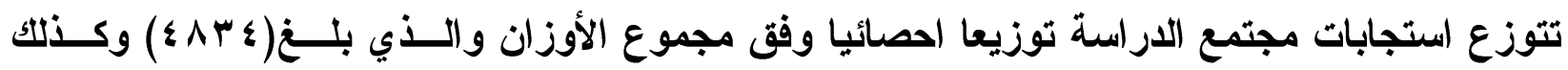

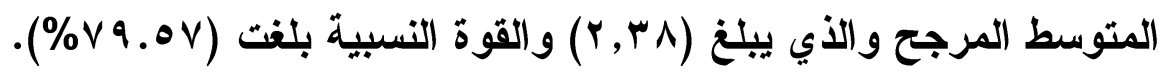

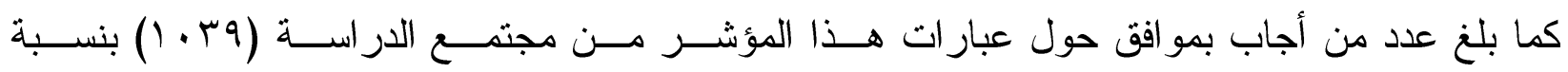

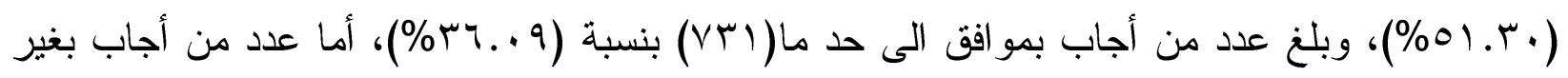

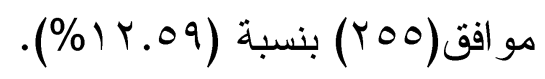
وقد جاءت العبار ات رقم (· ا، إ، 9) هي أكثر العبار ات قوة وتحقيقا بناء على الترتيب ووفق للوزن المرجح و القوة النسبية لكل عبارة حيث: - جاءت العبارة رقم ( (1) في التزتيب الأول و التي تشير الى أن المعسكر أتاح فرص التعلم التعــاوني

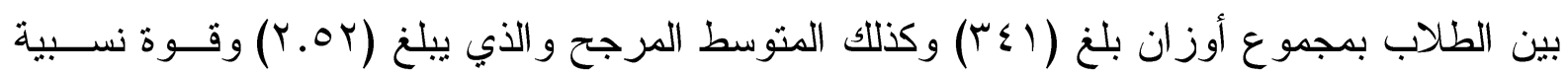

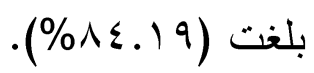

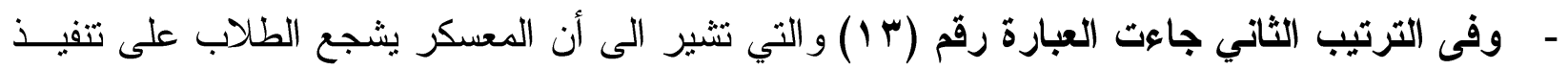

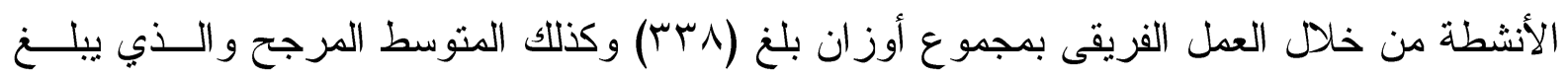

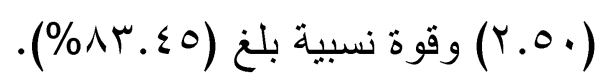
- وفى الترتيب الثالث جاعت العبارة رقم(9) و التي تزى أن المعسكر ساعد الطلاب على تغيير أفكار هم

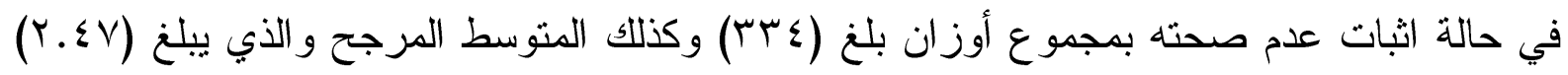

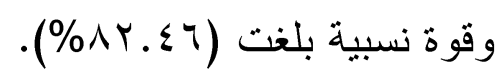

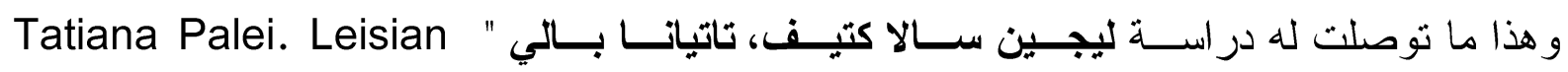
2015 و العمل الجماعي. 


\section{لـمجلة الخدمة الاجتماعية}

- وجاعت في المرتبة الاخيرة العبارة رقم (؟) و التي توضح أن المعسكر يساعد الطلاب على الابتعـاد

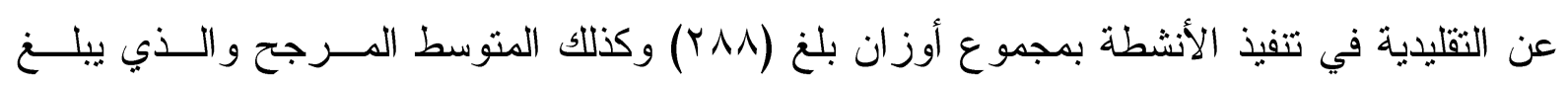

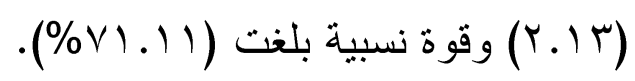

ويلاحظ من هذه الاستجابات أن أقلها قوة وتحقيقا كانت "المعسكرات لا تساعد الطلاب على الابتعـاد

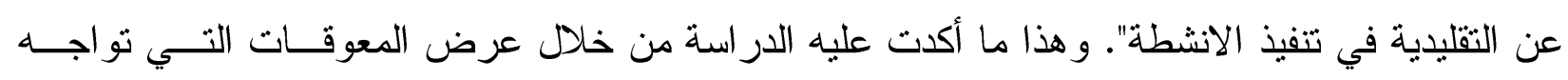

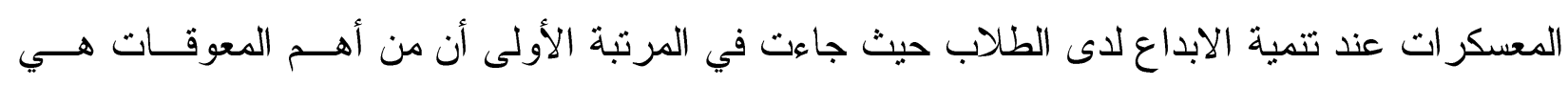

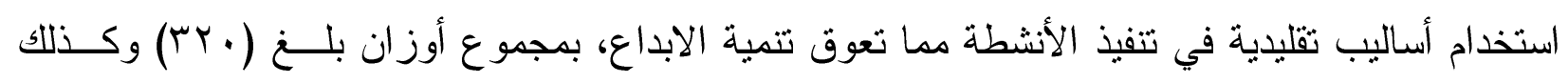

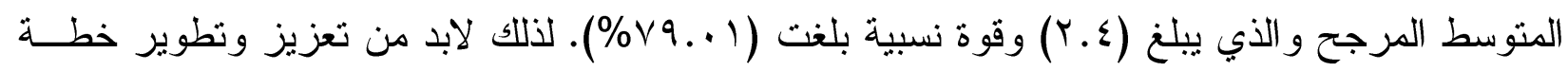
المعسكر ات لتنمية الابداع لاى الطلاب. 


\section{لـمجلة الخدمة الاجتماعية}

(ب) النتائج المتعلقة بالإجابة على التساؤل الفرعي الثاني للاراسة ومؤداه: ما دور المعكرات فــي تنمية الطلاقة لاى الثباب الجامعي؟

جدول رقم (r) (بأ)

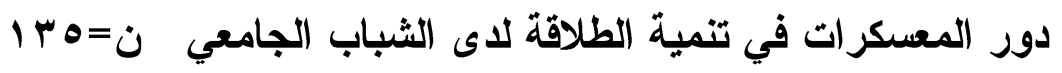

\begin{tabular}{|c|c|c|c|c|c|c|c|c|c|c|c|}
\hline \multirow{3}{*}{ 牙 } & \multirow{3}{*}{ |التقديرية } & \multirow{3}{*}{ | المتوسط } & \multirow{3}{*}{ 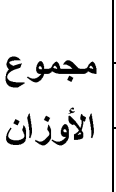 } & \multicolumn{6}{|c|}{ دور المعسكرات في تنمية الطلاقة لدى الثباب الجامعي } & \multirow{3}{*}{ العبارة } & \multirow{3}{*}{ r } \\
\hline & & & & \multicolumn{2}{|c|}{ 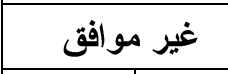 } & \multicolumn{2}{|c|}{ موافق إلى حد ما } & \multicolumn{2}{|c|}{ موافق } & & \\
\hline & & & & $\%$ & ك & $\%$ & ك & $\%$ & ك & & \\
\hline$\varepsilon$ & $\% \wedge \cdot . \leqslant q$ & Y.\&1 & דו & $\% 11.10$ & 17 & $\% r \leq . \wedge \mid$ & $\Sigma V$ & שr.ror\% & $V Y$ & 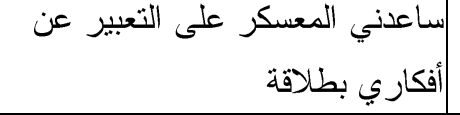 & 17 \\
\hline$\wedge$ & $\% \vee \wedge . \vee \neg$ & r.ru & M19 & $\% 11 . \wedge 0$ & 17 & $\% \leq$. & $0 \leqslant$ & $\% \leq \wedge . \mid \leq$ & 70 & |من فكرة في أقل وقت المعكر على تقديم أكثر & iv \\
\hline 7 & $\% \vee 9.0$. & r. rᄉ & MTY & שז.זוסו & 11 & $\% r \leq . \wedge \mid$ & $\varepsilon V$ & $\% 01.10$ & $V \cdot$ & | لساعدني المعسكر على تتمية قدرتي & 11 \\
\hline$\wedge$ & $\% \vee \wedge . \vee \neg$ & T. T. & M19 & $\% 11 . \wedge 0$ & 17 & $\% \leq$. & $0 \leqslant$ & $\% \leq \wedge . \mid \leq$ & 70 & |ساعدني المعسكر على اجراء & 19 \\
\hline 9 & $\% \vee \wedge .01$ & r.to & MA & سז.זורו & 11 & TV.VV & 01 & $\varepsilon \wedge . \wedge \wedge$ & 77 & 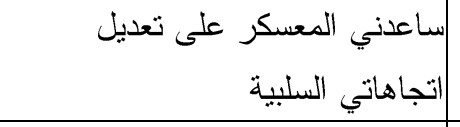 & $r$. \\
\hline V & $\% \vee q .40$ & T.MV & rri & $\%)$ r. & IV & $\% r v . . r \mid$ & 0. & $\% 0 \cdot . r v \mid$ & 41 & | التعبير عن رأيي بصر المعر في تتمية قدرتي على & r) \\
\hline$r$ & $\% \wedge \cdot .9 \wedge$ & r. $\varepsilon r$ & TrA & $\% \backslash$ Y.०q & IV & $\% M^{\prime} .10 \mid$ & $\varepsilon r$ & $\% 00.00$ & vo & |الانتقادات التي توجنى المعكر على تقبل لي & rr \\
\hline 0 & $\% \vee q . \vee 0$ & r.rq & Tr & $\% \backslash 1 . \wedge 0$ & 17 & $|\% r v . . r|$ & 0. & $\% 01.11$ & 79 & | جعلني المعسكر أركز على تتفيذ & r \\
\hline$y$ & $\% \vee 9.0$. & r.r人 & Trr & $\% \backslash \leq . \wedge \mid$ & $r$. & $\% \psi^{\prime}, . \wedge 0 \mid$ & $\varepsilon r$ & سדr.mor\% & $V Y$ & | ساعدني المعسكر على خلق الافكار & $r \leq$ \\
\hline 1 & $\% \wedge r . \leqslant 0$ & Y.o. & Th & $\% 9.74$ & 14 & $\% \mu \cdot . r v \mid$ & $\varepsilon 1$ & $\%$ \%. & $\wedge 1$ & 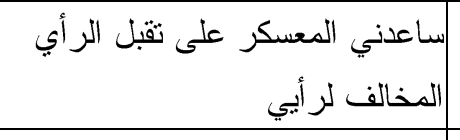 & ro \\
\hline 7 & $\% \vee 9.0$. & r.r人 & MYT & $\%) \leq . . v$ & 19 & سז.rז\% & $\varepsilon 0$ & $\% \circ r .09$ & YI & |لموضوني المعسكر الربط بين بعضها البعض & $r y$ \\
\hline$r$ & $\% \wedge \mid . \leqslant \wedge$ & Y. $\leqslant \varepsilon$ & . & $\% 11.11$ & 10 & |سז.rس\% & $\leqslant 0$ & $\% 00.00$ & vo & |إذا كان خاطئ المعسكر التر اجع عن قراري & $r V$ \\
\hline
\end{tabular}




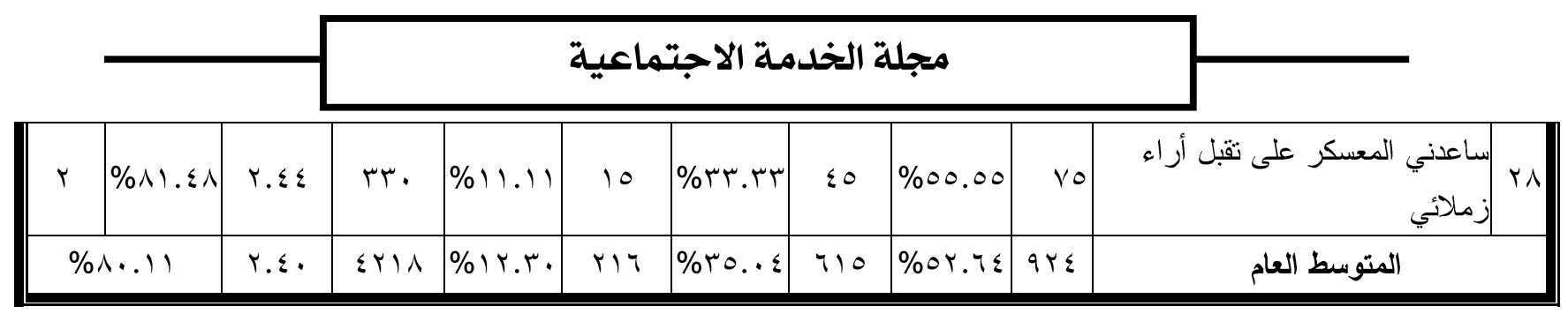

يتضـح من الجدول رقم (r) أن دور المعكرات في تنمية الطلاقة لاى الثباب الجامعي مرتفــع، حيــث

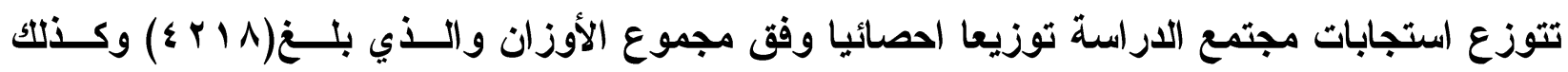

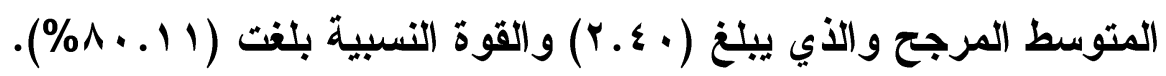

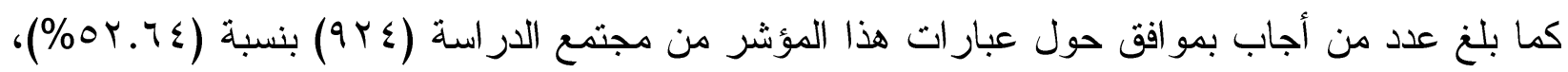

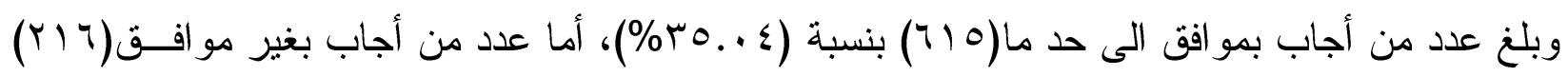

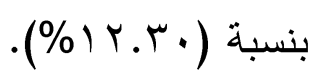

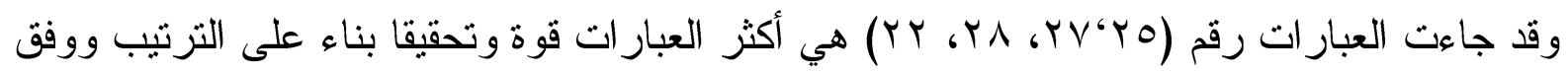

$$
\text { للوزن المرجح و القوة النسبية لكل عبارة حيث: }
$$

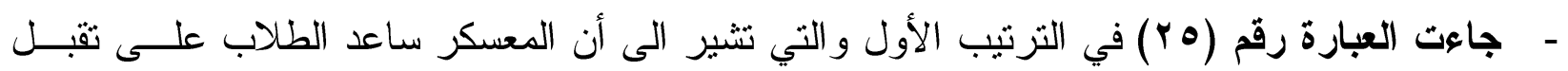

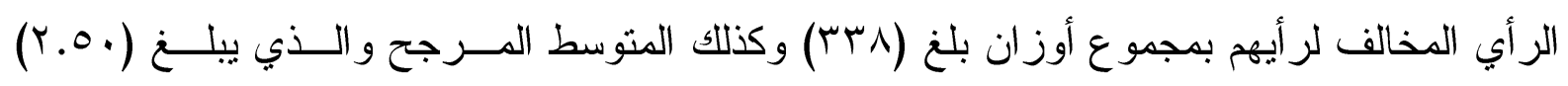

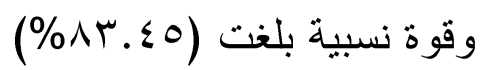

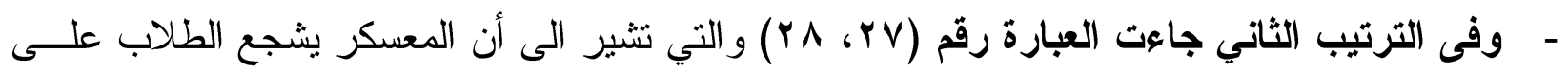

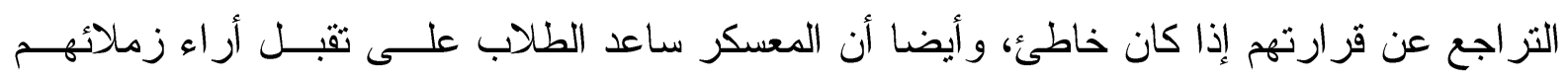

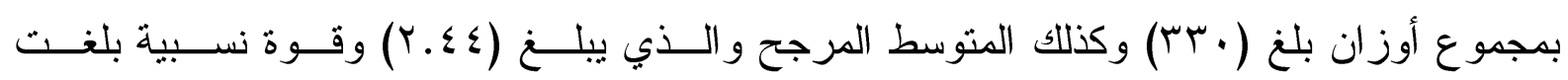
. $(\% \wedge) . \Sigma \wedge)$

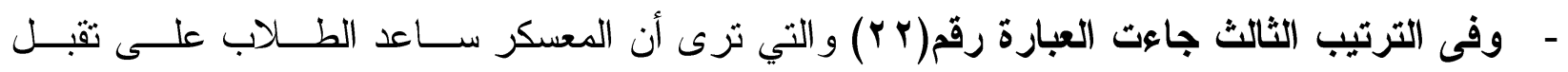

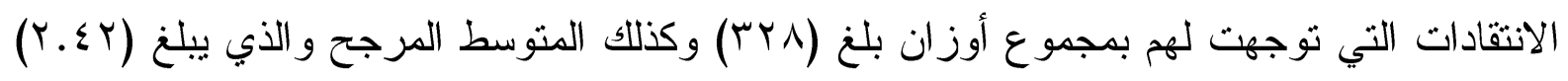

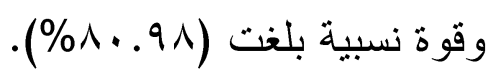

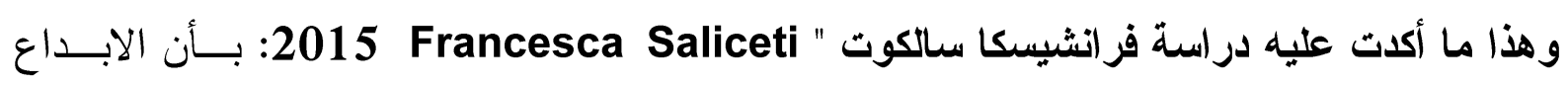
وسيلة لمساعدة الطلاب على تطوير التفكير النقدي وأساس لتعلم المعارف الجديدة واكتساب سلوكيات جديدة. - وجاعت في المرتبة الاخيرة العبارة رقم (·r) و التي توضح أن المعسكر ساعد الطلاب على تعـديل

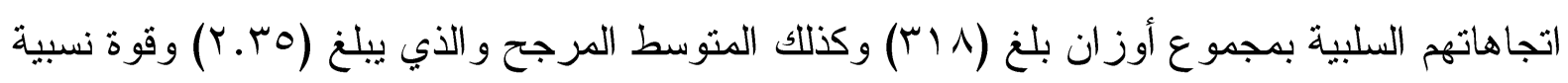

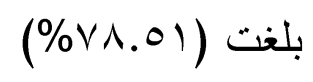




\section{لـمجلة الخدمة الاجتماعية}

ويلاحظ من هذه الاستجابات أن أقلها قوة وتحقبقا كانت المعكر ات تشاعد الطلاب على تعـديل اتجاهاتهم السلبية وبالتالي لابد من التركيز على الانشطة التعليمية التي تساهم في تثكيل سـمات

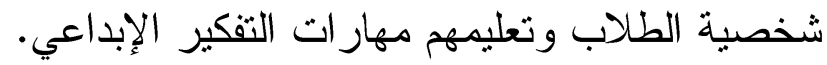

(ج) النتائج المتعلقة بالإجابة على التساؤل الفرعي الثالث للاراسة ومؤداه: ما دور المعسكرات فــي تنمية الحساسية بالمثكلات لاى الثباب الجامعي؟

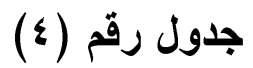

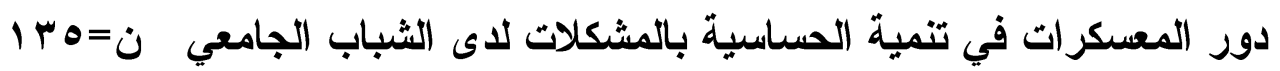

\begin{tabular}{|c|c|c|c|c|c|c|c|c|c|c|c|}
\hline \multirow{3}{*}{ 牙: } & \multirow{3}{*}{ |التقديرية } & \multirow{3}{*}{ | المرجو } & \multirow{3}{*}{ 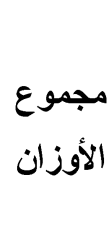 } & \multicolumn{6}{|c|}{ دور المعسكرات في تنمية الحساسية بالمشكلات لاى } & \multirow{3}{*}{ العبارة } & \multirow{3}{*}{ r } \\
\hline & & & & \multicolumn{2}{|c|}{ غير موافق } & \multicolumn{2}{|c|}{ موافق إلى حد ما } & \multicolumn{2}{|c|}{ موافق } & & \\
\hline & & & & $\%$ & ك & $\%$ & 5 & $\%$ & ك & & \\
\hline 1. & $\% \vee 7.0 \leq$ & r.rq & r. & $\% \backslash \varepsilon \ldots . V$ & 19 & $\% \leq Y . Y Y$ & or & $\% \leq r . v$. & 09 & |قبل حدوثني المعسكر أشعر بالمشكلات & rq \\
\hline 9 & $\% \vee \wedge .+r \mid$ & T.rs & 417 & $\%) \varepsilon . V$ & 19 & $\%$ Tr.vV & 01 & $\% \leq \wedge .1 \leq$ & 70 & |لقصاعدني المعسكر على معرفة أوجها & $r$. \\
\hline$r$ & $\% \wedge \cdot . \leqslant q$ & Y.\&I & דוד & $\% 11.10$ & 17 & $\% r \varepsilon . \wedge 1$ & $\varepsilon V$ & \%or.r. & VY & | & וr \\
\hline$\wedge$ & $\% \vee \wedge .01$ & r.ro & MIA & אז.דו & 11 & \%rv.vv & 01 & $\% \leq \wedge . \wedge \wedge$ & 77 & |للأسلفكير حل الإبداعي المشكلات كمنهر على استخدام & rr \\
\hline V & $\% \vee \wedge . \vee T \mid$ & T.MT & 419 & אז.דו & 11 & $\%$ \%v..r & 0. & $\% \leq 9.74$ & $T V$ & |لخاعدني المعسكر على وضع لمو اجهة مشاكلي & س \\
\hline 0 & $\% \vee 9 . \vee 0$ & $r . r q$ & Trt & $\% 1 Y .09$ & IV & $\%$ \%.00 & $\varepsilon \wedge$ & $\% 01.10$ & $V$. & | الأفكاردي الجديدة في حل مشاكلي على تقديم & r \\
\hline V & $\% \vee 9 .+1$ & T.TV & ru. & $\% \backslash \leq . \wedge \mid$ & $r$. & חז.דז\% & $\leqslant 0$ & $\% 01.10$ & $\gamma$. & |فلمني المعسكر التفكير المنطقي المشكلات الني تو اجهنى & ro \\
\hline 1 & $\% \wedge 1.9 \vee$ & r. $\leqslant 0$ & Trt & $\% 11.11$ & 10 & $\%$ I. & $\varepsilon r$ & $\% \circ V . . r$ & $V V$ & 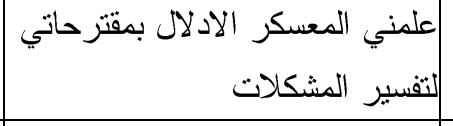 & דצr \\
\hline$r$ & $\% \wedge \cdot . \vee \leq$ & $r . \leqslant Y$ & TrV & $\% 11.10$ & 17 & $\%$ \%..V & $\leqslant 7$ & $\% 0 \varepsilon . . V$ & $V r$ & | & rv \\
\hline
\end{tabular}




\begin{tabular}{|c|c|c|c|c|c|c|c|c|c|c|c|}
\hline r & $\% \wedge \cdot . \vee \leqslant$ & $r . \varepsilon r$ & TrV & $\%)$ Y.09 & IV & $\%$ rr.oq & $\varepsilon \varepsilon$ & $\% \circ \leq . \wedge 1$ & $V \varepsilon$ & |علمني المعسكر المقارنة بين & rᄉ \\
\hline$\varepsilon$ & $\% \wedge$. & Y. & TrE & $\% 1 \cdot . r V$ & $1 \varepsilon$ & $\%$ r. ro & or & $\% 0 . . r v$ & 71 & 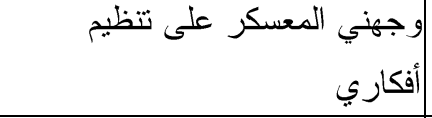 & rq \\
\hline$\wedge$ & $\% \vee \wedge .01$ & r.ro & M & $\%) \leq \ldots . V$ & 19 & $\%$ \%.rq & $\leqslant 9$ & $\% \leq 9.7 r$ & $7 V$ & 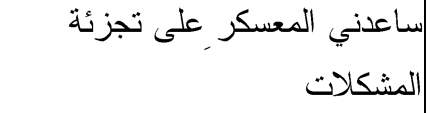 & $\varepsilon$ \\
\hline V & $\% \vee \wedge . \vee T$ & r.r. & r) & \% \% \% & 11 & $\% r v . . r$ & 0 . & $\% \leq 9.74$ & $7 V$ & |و جنوني المعسكر على تحليل المهام & $\leqslant 1$ \\
\hline 7 & $\% \vee 9$. ro & r.rv & Mr & $\% 10.00$ & YI & $\%(1.11$ & $\varepsilon r$ & \%or.r. & VY & |العاعدني المعسكر على أدر اك بين الاشياء وتفسير ها & $\varepsilon r$ \\
\hline$\wedge$ & $\% \vee \wedge .01$ & r.ro & M & $\% 17.49$ & rr & $\%$ M. Io & $\varepsilon r$ & $\% 01.10$ & $V$. & للمشكلات التي تو اجنى المعكى توقع الحل & $\varepsilon r$ \\
\hline$\wedge$ & $\% \vee \wedge .01$ & r.to & M & $\%) 7.4 q$ & rr & $\%$ \% . & $\varepsilon$ & $\% 01 . \wedge 0$ & $V \cdot$ & |ثجعني المعسكر على جمع ملى بدقة في حشاكلي & $\leq \varepsilon$ \\
\hline \multicolumn{2}{|c|}{ \%vq. ro } & r.MV & דוא & $\%)$ T.EV & (q) & $\%$ \% T.rv & VTY & $\% 01$. Yo & $11 \cdot v$ & المتوسط العام & \\
\hline
\end{tabular}

يتضح من الجدول رقم (ع) أن دور المعكرات في تنمية الحساسية بالمشكلات لاى الثباب الجـامعي

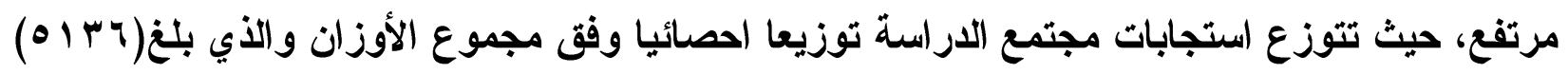

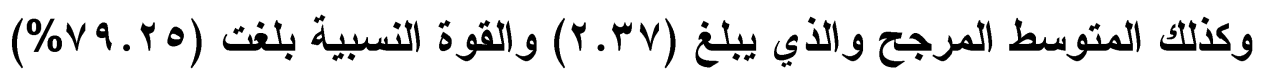

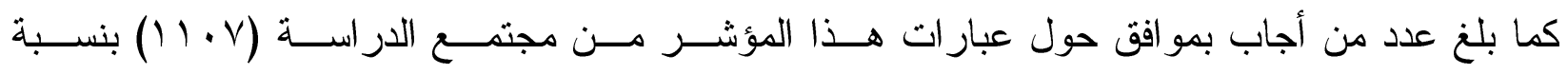

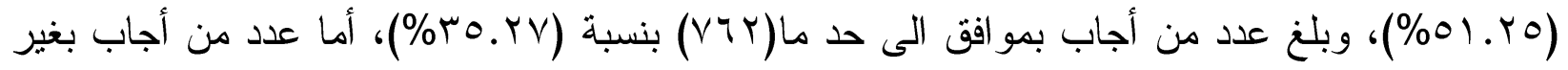

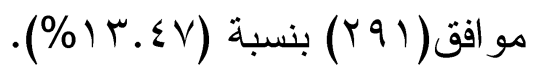

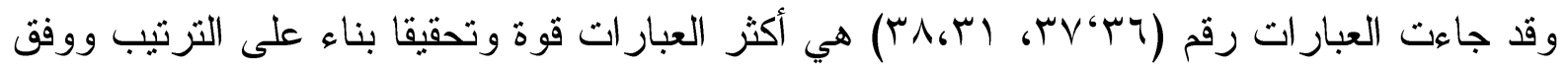
للوزن المرجح و القوة النسبية لكل عبارة حيث: - جاءت العبارة رقم (؟r) في الترتيب الأول و التي تشير الى أن المعسكر ساعد الطلاب علــى الادلال

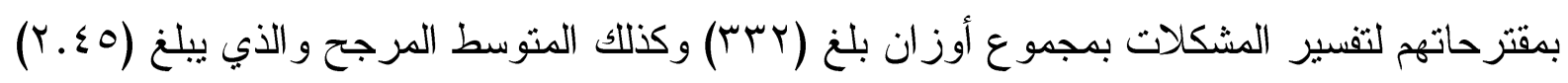

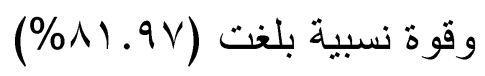

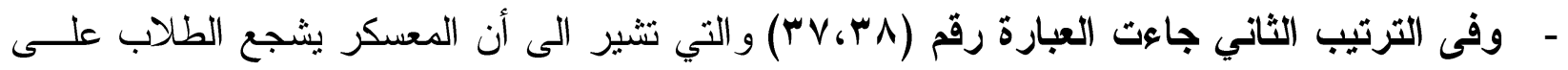
عرض حلول إيجابية للمشكلات، وأيضا ساعدهم على المقارنة بين الحلول المختلفة قبل اتخاذ القرار

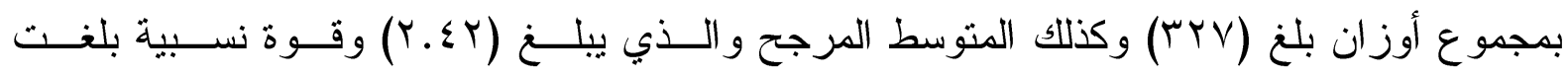
.(\%^. . . $\Sigma)$ 


\section{口مجلة الخدمة الاجتماعية}

- وفى الترتيب الثالث جاعت العبارة رقم(اس) و التي تشير أن المعسكر ساعد الطلاب على وضع رؤية

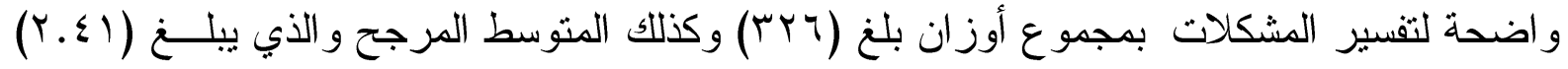

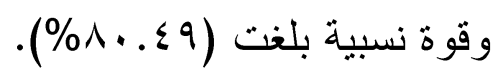

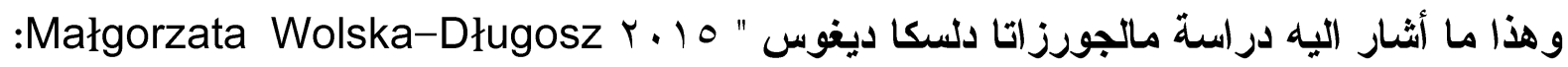
على أن الابداع يعتبر وسيلة لإيجاد حلول للمشكلات، لذا توصى الدر اسة بضرورة اهتمام المسئولين

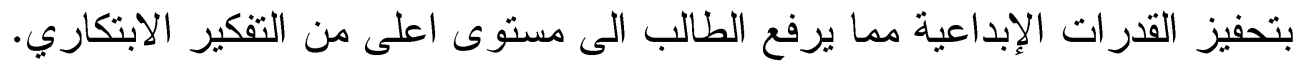

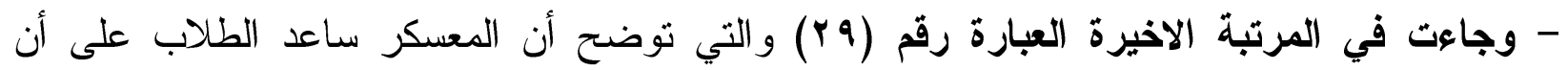
يشعرون بالمشكلات قبل حدوثها أو أكثر بمجموع أوزان بلغ (· (ب) وكذلك المتوسط المرجح و الذبي يبلغ

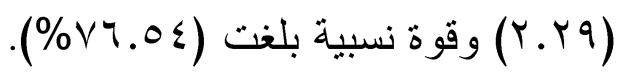
ويلاحظ من هذه الاستجابات أن أقلها قوة وتحقبقا كانت المعسكرات لا تساعد الطلاب على أن يشعروا بالمشكلات قبل حدوثها. وهذا يدل على أن الطلاب ليس لايهم قدرة عالية على التتبؤ بالمكلات ولهذا لابد من ضرورة نشر ثقافة الابداع لديهم وتدريبهم على انتاج معارف جديدة تساعدهم على وضع خطط لمو اجهه مشكلاتهم بصورة مستمرة.

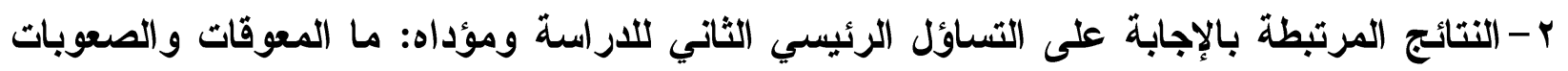

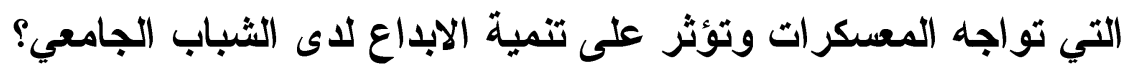

\section{جدول رقم (0)}

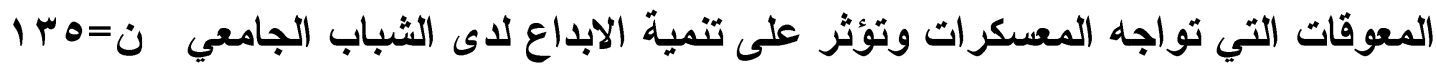

\begin{tabular}{|c|c|c|c|c|c|c|c|c|c|c|c|}
\hline \multirow{3}{*}{ 冏: } & \multirow{3}{*}{ التقديرية } & \multirow{3}{*}{ المرجع } & \multirow{3}{*}{ 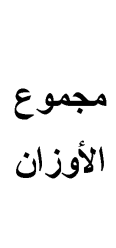 } & \multicolumn{6}{|c|}{ المعوقات التي تواجه المعسكرات وتؤثر على تنمية } & \multirow{3}{*}{ العبارة } & \multirow{3}{*}{ م } \\
\hline & & & & \multicolumn{2}{|c|}{ غير موافق } & \multicolumn{2}{|c|}{ مو افق إلى حد ما } & \multicolumn{2}{|c|}{ موافق } & & \\
\hline & & & & $\%$ & st & $\%$ & ك & $\%$ & كs & & \\
\hline 1 & $\% \vee 9 .+1$ & r.乏 & rt. & $\% 10.00$ & $r_{1}$ & $\%$ \%. & $\varepsilon r$ & $\% 0 r .09$ & $v_{1}$ & |الانشطة مما يعوق الابداع أساليب تقليدية في تتفيذ & 1 \\
\hline 9 & $\% \vee \leqslant .07$ & r.r & $r \cdot r$ & $\%$ Y. . ¿ᄉ & rq & 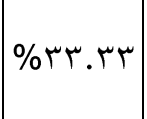 & «o & $\% \leq 0.11$ & 71 & 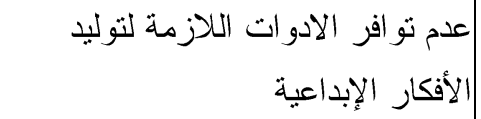 & r \\
\hline V & $\% \vee 0.00$ & r.r & $r \cdot \tau$ & $\% r . . V \varepsilon$ & rᄉ & $\%$ \%.А० & $\varepsilon r$ & $\% \leq v . \varepsilon$. & $7 \varepsilon$ & 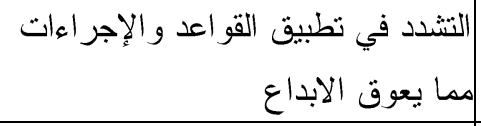 & $r$ \\
\hline$\wedge$ & $\% \vee 0.7$ & r.r & $r \cdot \varepsilon$ & $\% r$. & $r v$ & $\% \leftarrow \varepsilon .11$ & $\varepsilon v$ & $\% \leq 0.11$ & 7 & عدم وجود بر امج متخصصة لاكتثاف & $\varepsilon$ \\
\hline
\end{tabular}




\section{口ـمجلة الخدمة الاجتماعية}

\begin{tabular}{|c|c|c|c|c|c|c|c|c|c|c|c|}
\hline & & & & & & & & & & |المبدعين و المو هو بين & \\
\hline 9 & $\% \vee \leqslant .07$ & r. $r$ & $r \cdot r$ & $\% r$. & rV & $\%$ \%.r. & $\leqslant 9$ & $\% \leq r . v \cdot$ & .09 & المعسكر التشجيع بعرض مقترحاتتا في & 。 \\
\hline 4 & $\% \vee 0.1$. & r.r & $r \cdot v$ & $\% \backslash \wedge .01$ & ro & $\%$ \% 0.00 & $\varepsilon \wedge$ & $\% \leqslant 0.9 r$ & $T Y$ & نعدم تو افز الوقت اللازم لأبداع الرأي & 7 \\
\hline$\wedge$ & $\% \vee 0 . .7$ & r.r & $r \cdot \varepsilon$ & $\%$ \%.V .V & rᄉ & שr.rז\% & $\leqslant 0$ & $\% \leqslant 0.94$ & $T Y$ & |عدم السماح للطلاب بحرية الر أي & v \\
\hline 0 & $\% \vee 7 . \vee 9$ & r.r & 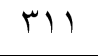 & $\% \backslash V . . r$ & r & $\% r 0.00$ & $\varepsilon \wedge$ & $\% \leq \vee . \varepsilon \cdot$ & $T \varepsilon$ & تبنىى طريقة واحدة في التفكير & $\wedge$ \\
\hline ir & \%VY.rs & r.l & rar & \%หr.тT & ra & \%หя.тr & $\varepsilon \cdot$ & $\% \varepsilon r . v \cdot$ & .99 & |الخوف من سخرية الاخرين & 9 \\
\hline 11 & $\% \vee r . \wedge r$ & r.l & r9o & $\%$ \% & 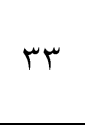 & $\%$ rr.o9 & $\leqslant \varepsilon$ & $\% \leqslant Y .97$ & $0 \wedge$ & |لابدرة عدد الطلاب بالمعسكر مما يعوق & 1. \\
\hline r & $\% \vee \wedge . Y \vee$ & r.r & miv & $\% \backslash \leq . \vee V$ & 19 & \%rv.or & 0. & $\% \leq \wedge . \wedge \wedge$ & 77 & تصاعد على تتمية الابداع المو المادية اللازمة التي & 11 \\
\hline$\varepsilon$ & $\% \vee \vee . . r$ & r.r & m & $\% 17.49$ & rt & $\%$ \%ัт.тq & $\varepsilon 9$ & $\% \leq \vee . \varepsilon$. & $7 \varepsilon$ & |وتعرف الطلاب من الوقوع في الأخطاء & ir \\
\hline 1 & $\% \vee 9 . .1$ & Y.乏 & rt. & $\% \backslash \leq . \wedge 1$ & $r \cdot$ & אז. & $\leqslant 0$ & $\% 01.10$ & $v \cdot$ & عرض الأفكار الجديدة الوقت المعد للمعسكر في & $\pi$ \\
\hline r & $\% \vee \wedge .+r$ & r.r & MIT & ?\%) V.VV & $r \varepsilon$ & $\% r \cdot r v$ & $\leqslant 1$ & $\% 01.10$ & $v \cdot$ & تتمية القدر ات الإبداعية مناخ تعليمي يشجع على & $1 \varepsilon$ \\
\hline 1. & \%Vr.ru & r.l & rqv & \%とร.ะร & rr & \%r1.11 & $\varepsilon r$ & $\%$ \%ร. $\{\varepsilon$ & 7. & عدم ثقة الطلاب بأنفسهر & 10 \\
\hline 11 & \%४r.Ar & r.l & r9o & \%イร.ะร & rr & \%rr.09 & $\varepsilon \varepsilon$ & $\% \leqslant r .97$ & 01 & |عدم وجود قيادة إدارية مؤهلة & 17 \\
\hline 9 & $\% \vee \circ . \wedge$. & r.r & $r \cdot v$ & $\% r$. & rV & $\%$ rr.oq & $\varepsilon \varepsilon$ & $\% \leq \vee . \varepsilon$. & $T \varepsilon$ & | لتوليد الأفكار الإبداعدام أساليب منتوعة بالمعسكر & iv \\
\hline 11 & \%УY.AY & r.l & r9o & \%rr.v. & rr & $\% r \leq . v$ & $\leqslant 7$ & $\% \leq Y . Y Y$ & $O V$ & الأدو ار و المسؤوليات غير واضحة & 11 \\
\hline \multicolumn{2}{|c|}{$\% \vee 0.0$} & r.r & $00 . r$ & $\%$ \%... & 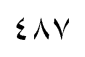 & \% & 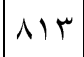 & $\% \leq \div .0$ & $11 \pi$. & المتوسط العام & \\
\hline
\end{tabular}

يتضح من الجدول رقم (0) أهم المعوقات والصعوبات التي تواجه المعكرات وتؤثر على تنمية الابداع لاى الثباب الجامعي والتي أثثار اليه الطلاب بمستوى متوسط، حيث تتوزع استجابات مجتمع الاراسة

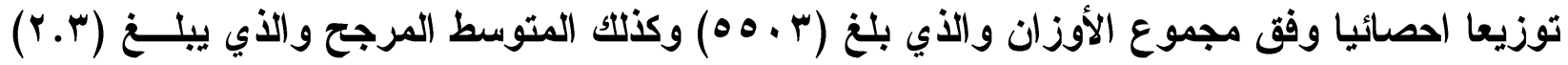

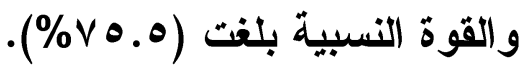

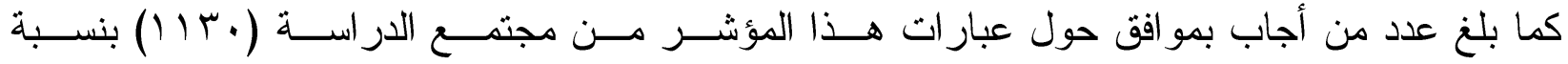

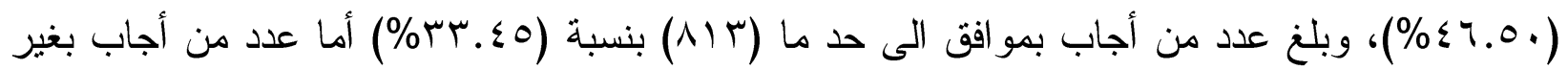

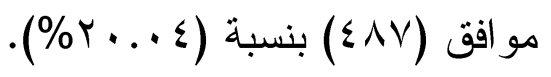




\section{لــــلة الخدمة الاجتماعية}

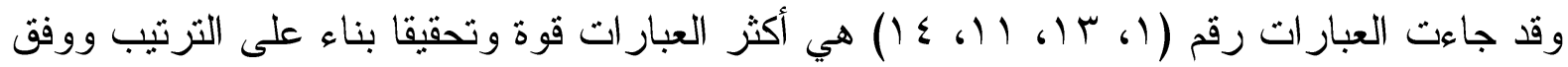

للوزن المرجح و القوة النسبية لكل عبارة حيث:

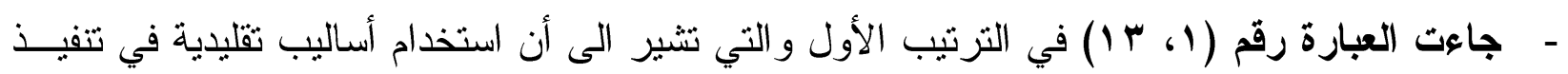

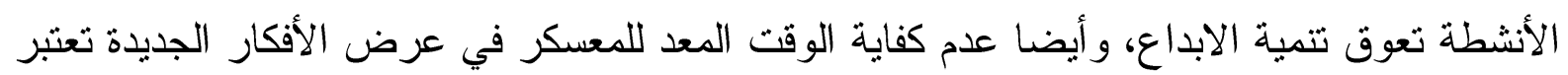

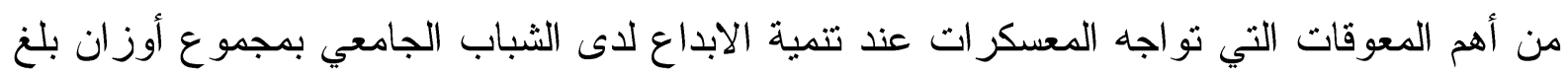

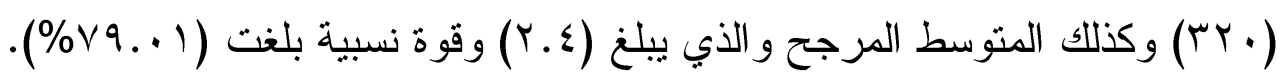

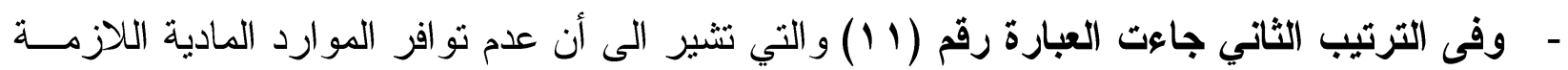

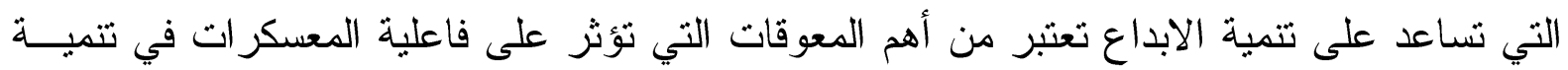

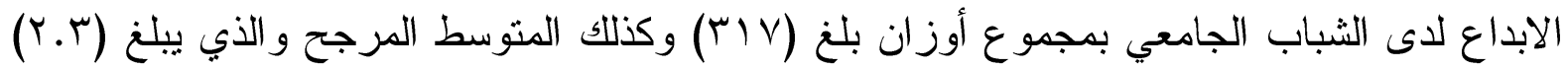

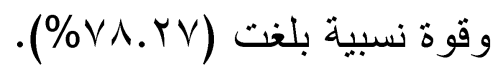
- وفى الترتيب الثالث جاءت العبارة رقم(ع 1) و التي تشير أن عدم تو افر مناخ تعليمي يشجع على تنمية

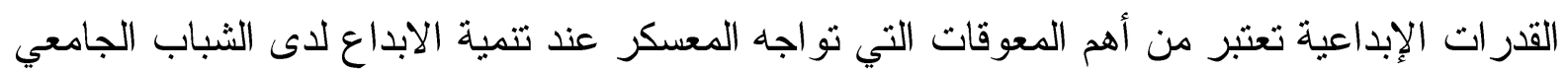

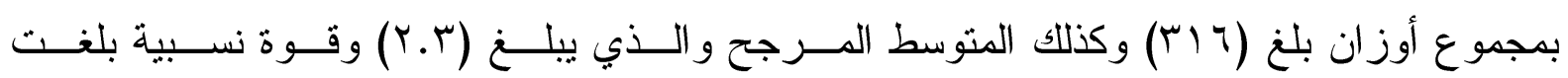

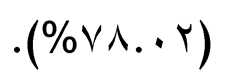

- وجاعت في المرتبة الاخيرة العبارة رقم (9) و التي توضح أن الخوف من سخرية الاخرين تعتبر من

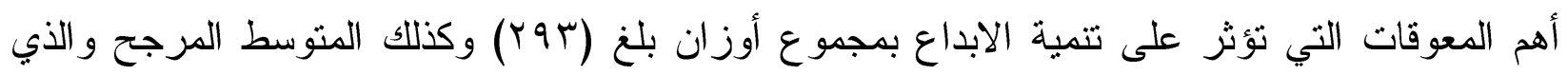

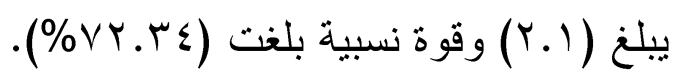
ويلاحظ من هذه الاستجابات أهم المعوقات والصعوبات التي تؤثر على فعالية المعسكر عند تتمية الابداع

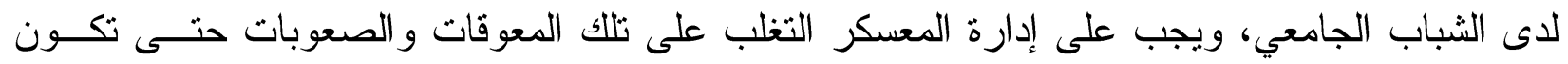
المعسكرات أكثر فاعلية حتى يستفيد الطلاب من تتمية قدر اتهم و اكتشاف مو اهبهر و إيداعاتهم. 


\section{口مجلة الخدمة الاجتماعية}

r- النتائج المرتبطة بالإجابة على التساؤل الرئيسي الثالث للاراسة ومؤداه: ما المقترحات التي تزيد من فعالية المعكرات في تنمية الابداع لاى الثباب الجامعي؟ بالهي

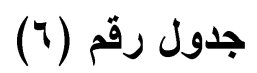

المقترحات التي تزيد من فعالية المعكرات في تنمية الابداع لاى الثباب الجامعي ن=هـ

\begin{tabular}{|c|c|c|c|}
\hline 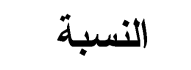 & التكر ار & 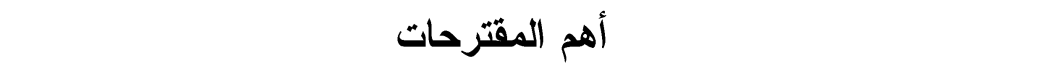 & b \\
\hline$\% 9 r .09$ & re & استخدام أساليب ثربوية ابداعية لنطوير الأفكار الإبداعية & 1 \\
\hline$\% \wedge r .97$ & $11 \mathrm{r}$ & غرس مبادئ الابداع و الابتكار و التجديد في نفوس الطلاب & r \\
\hline$\% \wedge \wedge . \wedge \wedge$ & ir. & منح الطلاب فرص التعبير عن الرأي بحرية مما يساعد على الابداع & $r$ \\
\hline$\% 97 . \wedge r$ & $11 r$ & العمل على اكتشاف المو اهب و القدر ات الابتكارية وتتميتها & $\varepsilon$ \\
\hline$\% \wedge \wedge . \wedge \wedge$ & ir. & ضرورة عقد ندو ات وورش عمل لتدريب الطلاب على الابداع و الابتكار & $\circ$ \\
\hline$\% \wedge \wedge .1 \varepsilon$ & 119 & تطوير المناهج التعليمية التي تساعد على الابداع & 7 \\
\hline$\% \wedge \vee . \varepsilon$ & 111 & وضع بر امج لاكتشاف المبدعين وتشجعيهم & v \\
\hline$\% \wedge \wedge .1 \varepsilon$ & 119 & توفير الإمكانيات اللازمة الني تساعد على تتمية الابداع & $\wedge$ \\
\hline$\% \wedge \varepsilon . \varepsilon \varepsilon$ & $11 \leq$ & توفير مناخ تعليمي مناسب يساعد على تتمية الابداع & 9 \\
\hline$\% 94.09$ & iro & تقديم الدعم المادي المعنوي للمبدعين & 1. \\
\hline$\% \wedge \wedge .1 \leq$ & 119 & الاستقلالية و الحرية الذاتية في اتخاذ القرارات & 11 \\
\hline$\% \wedge 0.11$ & 110 & تشجيع التفاعل البناء بين الافر اد و الجماعات & ir \\
\hline$\% \wedge r .94$ & 114 & الحد من الاشر اف المفرط على الطلاب أثناء نأدية الأنشطة & 14 \\
\hline$\% \wedge \leq . \leq \varepsilon$ & $11 \leq$ & تفعيل استر اتيجيات حديثة بالتنريس لتنمية التفكير الإبداعي & $1 \varepsilon$ \\
\hline$\% \wedge \vee . \varepsilon$ & 111 & تدريب الطلاب على المرونة الفكرية في حلن المشكلات التي تو اجههم & 10 \\
\hline \%^r.レ. & $11 r$ & الطثلاب المعسكرات بالبر امج المتجددة الثي تعمل على تتمية الابداع لدى & 17 \\
\hline$\% \wedge \wedge . \wedge \wedge$ & ir. & تتظيم لقاءات مفتوحة بين الطلاب المبدعين & iv \\
\hline
\end{tabular}

يتضح من الجدول رقم (†) أهم المقترحات التي تزيد من فعالية المعكرات في تنمية الابداع لدى الثباب الجامعي حيث أجمع الطلاب: 


\section{لمـلة الخدمة الاجتماعية}

- - بضرورة استخدام أساليب تربوية ابداعية لتطوير الأفكار الإبداعية، وأيضا ضرورة تقديم الدعم

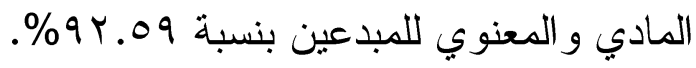

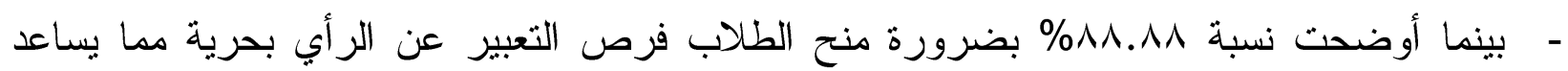

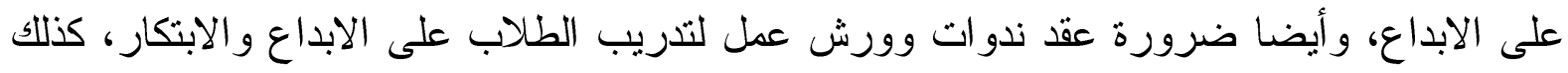
تنظيم لقاءات مفتوحة بين الطلاب المبدعين.

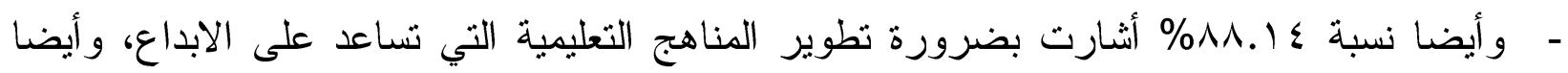
توفير الإمكانيات اللازمة التي تساعد على تتمية الابداع، كما تؤكد على ضرورة الاستقلالية والحرية

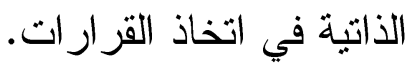

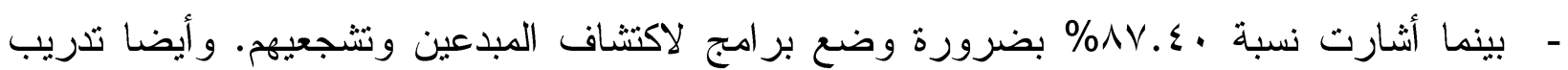
الطلاب على المرونة الفكرية في حل المشكلات التي تو اجهره.

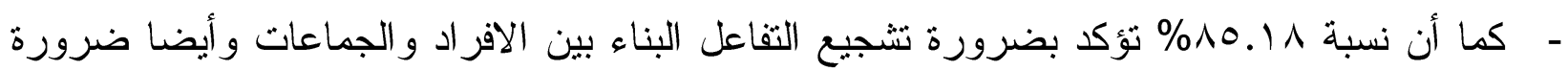
توفير مناخ تعليمي مناسب يساعد على تتمية الابداع وتفعيل استراتيجيات حديثة بالتدريس لتنمية

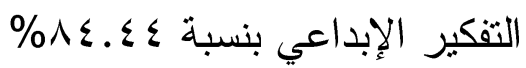

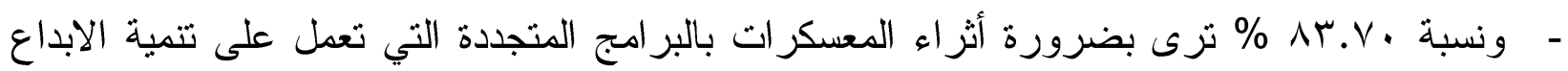

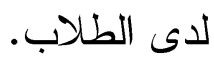

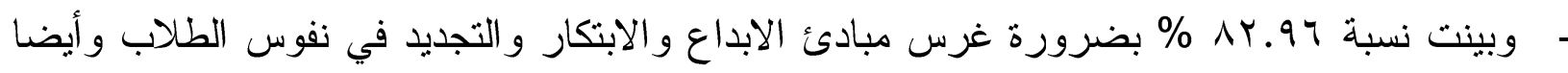
ضرورة العمل على اكتثاف المواهب والقدرات الابتكارية وتتميتها، كما يؤكدوا على ضرورة الحد لداني من الاشر اف المفرط على الطلاب أثناء تأدية الأنشطة.

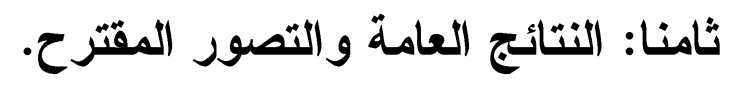
أسفرت الاراسة على النتائج التالية: ا-بالنسبة للنتائج الخاصة بالتساؤل الرئيسي الأول ومؤداه: ما دور المعسكرات في تنمية عناصــر

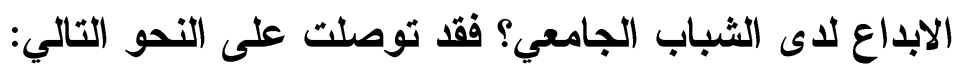
(أ) للمعكرات دور مرتفع في تنمية الاصالة لاى الثباب الجامعي مرتبة تنازليا وهي كالتالي: - اتاح المعسكر فرص التعلم التعاوني بين الطلاب. - يشجعه المعسكر على تتفيذ الأنشطة من خلا لإن العمل الفريقى. - ساعدهم المعسكر على تغيير أفكار هم في حالة اثبات عدم صحته.

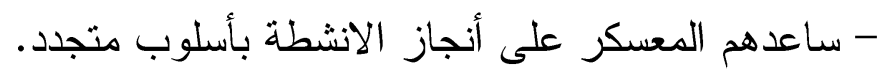




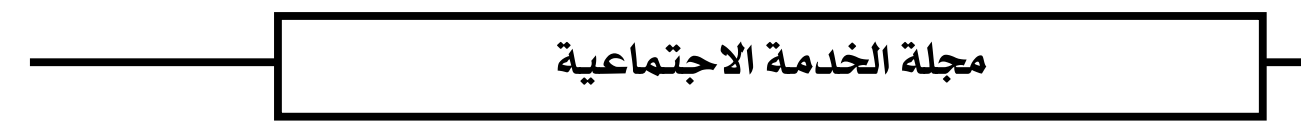

$$
\text { - ساعدهم المعسكر في تتمية مهار اتهم القيادية. }
$$

- ساهم المعسكر في تتمية قدرتهم على التعبير عن رأيهم بحرية و أيضا تثنجيعهم على المشاركة في أكثر من نثاط

- علمه المعسكر أساليب جديدة في توليد الأفكار الإبداعية. - ساعدهم المعككر على استخدام أسلوب العصف الذهاب الذهني في توليد الأفكار الإبداعية.

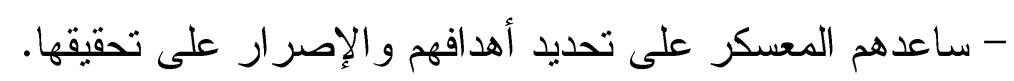
- ساعدهم المعكر على اكتثاف مواهيهم. - حفز هم المعسكر على ابتكار أنشطة وبر امج جديدة. - شجعهم المعكر على تحقيق النجاح بقوة و أيضا أناح لهم فرصة كاندة كافية على عرض أفكار هم الجديدة بحرية.

- علمهم المعسكر الابتعاد عن التقليدية في تنفيذ الأنثطة. (ب) للمعكرات دور مرتفع في تنمية الطلاقة لاى الثباب الجامعي مرتبة تنازليا وهي كالتالي: - - ساعدهم المعكر على تقبل الر أي المخالف لر أيهم.

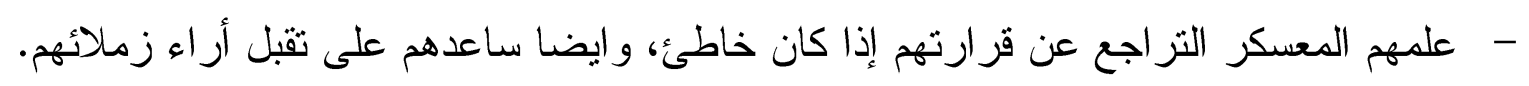

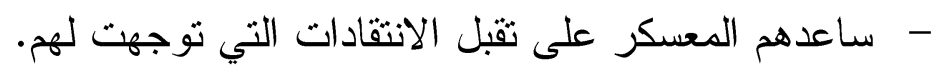
- - ساعدهم المعسكر على التعبير عن أفكار هم بطلاقة. - - - جعهم المعكر يركزوا على تتفيذ الأنشطة بجدارة. - - علمهم المعسكر الربط بين الموضوعات بيعضها البعض، وايضا خلق الافكار الجديدة بدقة، كما

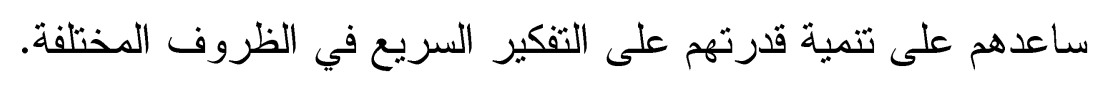

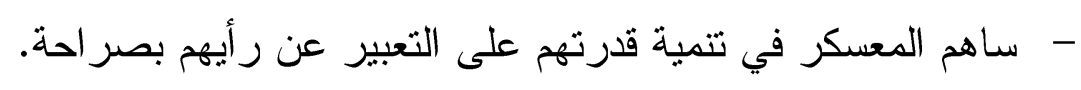

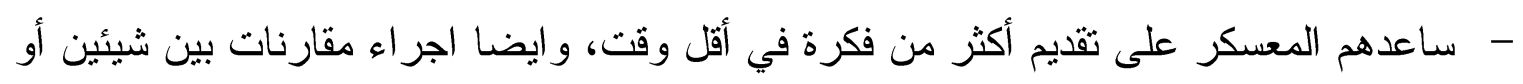
أكثر - ساعدهم المعسكر على تعديل اتجاهاتهم السلبية. (ج) للمعكرات دور مرتفع في تنمية الحساسية بالمشكلات لاى الثباب الجامعي مرتبة تنازليا وهي كالتالي: - علمهم المعكر الادلال بمقترحاتهم لتفسير المشكلات. 


\section{لـمرجلة الخدمة الاجتماعية}

- - علمهم المعكر عرض حلول إيجابية للمشكلات و أيضا المقارنة بين الحلول المختلفة قبل اتخاذ

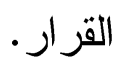

- ساعدهم المعسكر على وضع رؤية واضحة لتفسير المشكلات. - - وجهم المعسكر على تتظيم أفكاري.

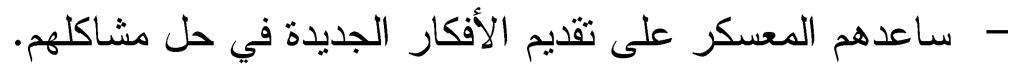
- ساعدهم المعسكر على أدر اك العلاقة بين الاشياء وتفسيرها.

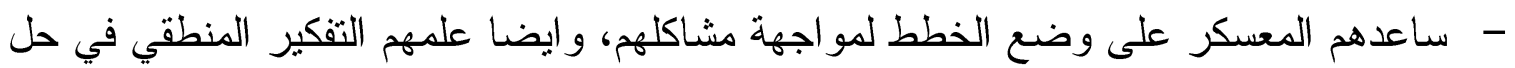
المشكلات التي تو اجههم، وتوجيهم على تحليل المهام وتوظيفها.

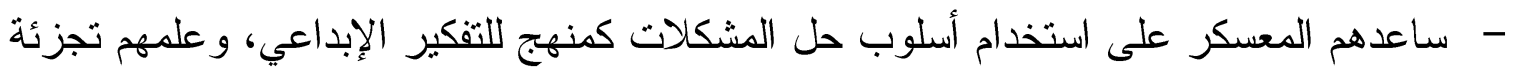

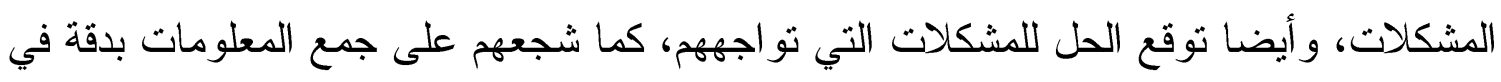
حل مشاكلهم. - ساعدهم المعسكر على معرفة أوجه القصور و الضعف في حياتهم. -جعلهم المعسكر يشعرون بالمشكلات قبل حدوثها.

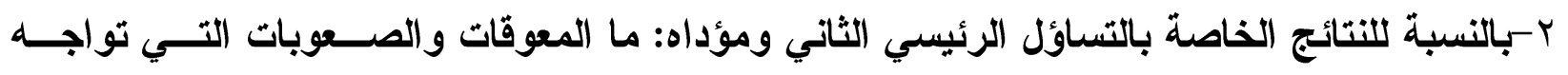

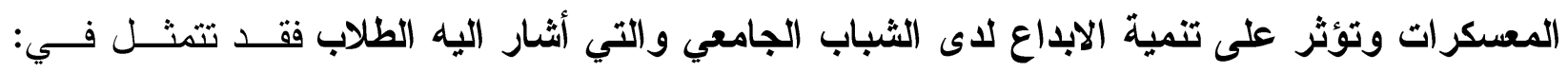

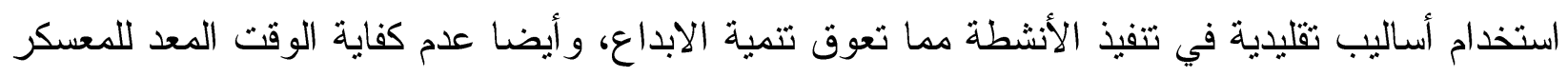

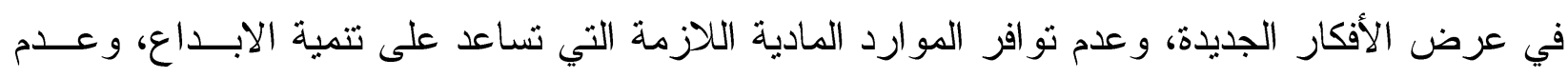
تو افر مناخ تعليمي يشجع على تتمية القدرات الإبداعية.

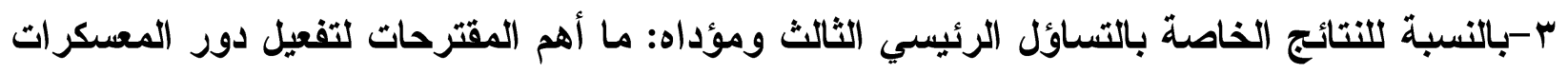
في تنمية الابداع لاى الثباب الجامعي فقد تمثلت في ضرورة استخدام أساليب تربوية ابداعيــة لتطـــــير

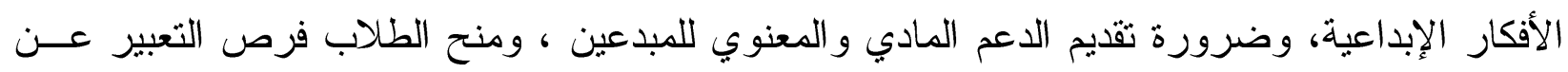

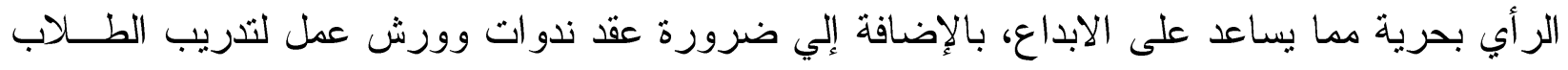

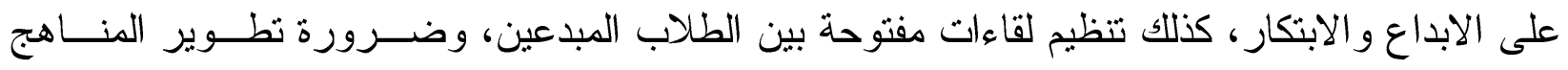

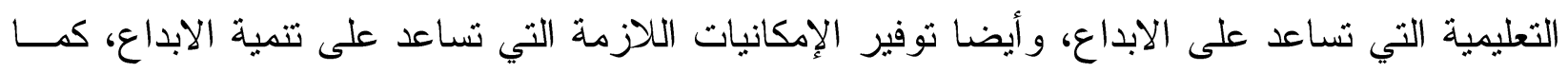

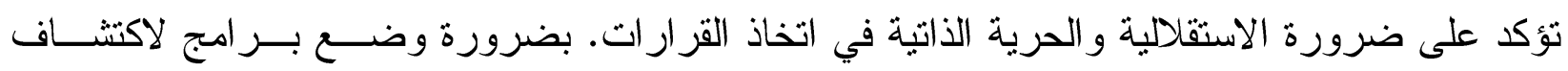
المبدعين وتتجعيهم. و أيضا تدريب الطلاب على المرونة الفكرية في حلن المشكلات التي تواجهره. 


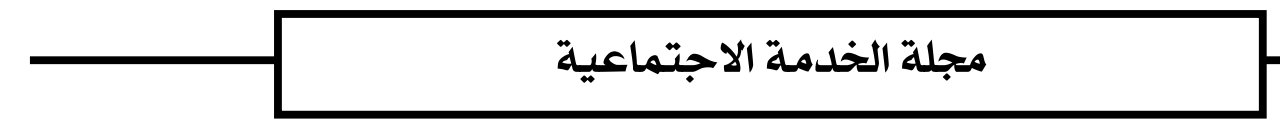

التصور المقترح لتفعيل دور المعكرات في تنمية الابداع لاى الثباب الجامعي:

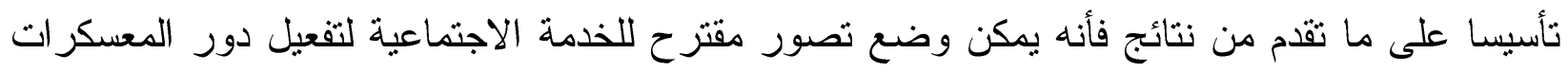

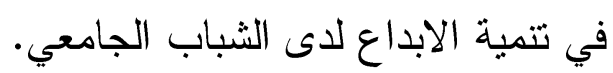

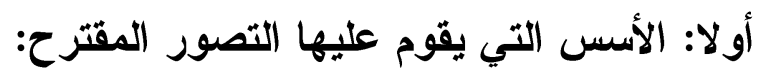

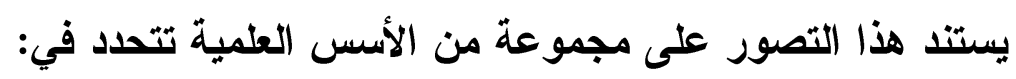
ا-بنائج البحوث و الدر اسات السابقة. ب- ب- بائج الدر اسة الر اهنة. ب-الإطار النظري لدور المعسكرات في تتمية الابداع. ثانيا: الافتر اضات الأساسية للتصور المقترح: 1- إندة مشاركة الطلاب في الأنشطة الطلابية. r-مرونة المعسكرات بتطور الظروف الاقتصادية والاجتماعية بالمجتمع.

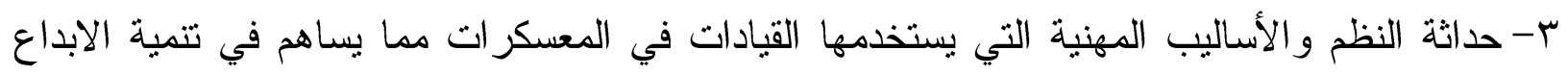
لدى الطلاب. ؟ - خلق مناخ تعليمي مناسب يساعد على تتمية الابداع لاى الطلاب. ثالثا: أهداف التصور المقترح: يسعى التصور المقترح إلى تفعيل دور المعسكر ات في تنمية الابداع لدى الثباب الجامعي و التي تمثلت في الاتي: -

1- اتاحة الحرية للطلاب ليبدعوا، ومساعدة الطلاب على حل مشاكلهم وتنمية قراتهم وذلك من خلال:

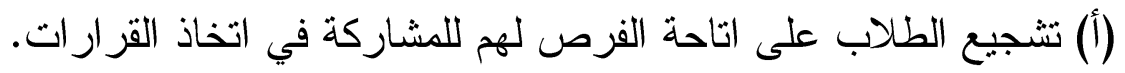
(ب) التخلي عن الروتين و اللامركزية في التعامل مما ينمى القدرة الإبداعية. (ج) يجب ملاحظة الطلاب وتقويمها و أخذ الجيد وترك الرديء مع وضع التعديلات اللازمة للأفضل.

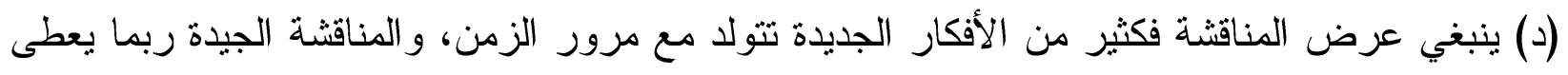
مقدرة على تتفيذها. (ه) تشجيع الطلاب على انتاج الإفكار الابداعية. (و) تشجيع الطلاب على تقبل الاختلافات بين الآراء في المو اضيع المختلفة.

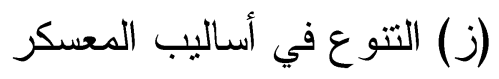
(ح) احتر ام الطلاب المو هوبين وتهيئة الظروف المناسبة لهم للتعلم و التعليم. 


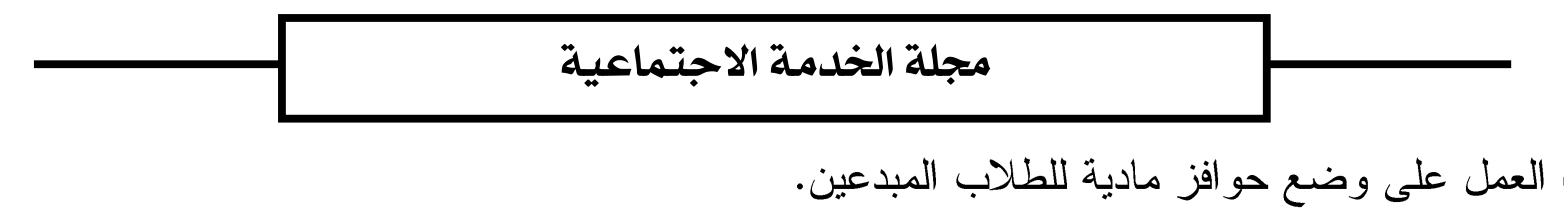

r-تصميم برامج لاكتثاف المو هوبين والمبدعين وذنك من خلادل:

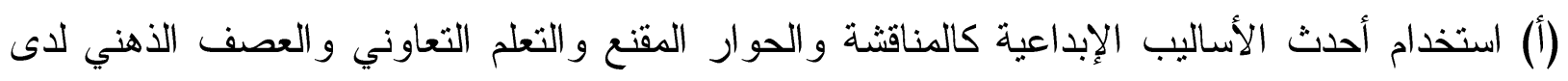

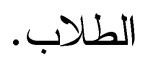

(ب) نشر ثقافة الابداع وتتميتها للى الطلاب. (ج) توفير كافة المو ارد و الإمكانيات المادية و المعنوية لتنفيذ الأفكار الإبداعية لادى الطلاب. (د) العمل على تنظيم دورات تدريبية تخصيصية لخصائص الابداع. (ه) اتاحة الفرصة لجلسات التعليم الذاتي والهناقثة الحرة. (و) تتمية مهارات التفكير الإبداعي لدى الطلاب. (ز) تصميم استراتيجية واضحة مبنية على معايير دقيقة لاكتثاف المو هو بين و المبدعين r-تحسين قدرة المعسكرات في تنمية الابداع لاى الطلاب وذلكك من خلال:

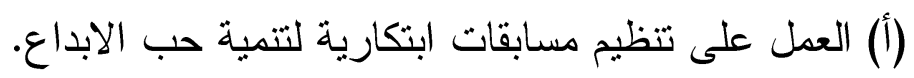
(ب) تتفيذ الأنثطة بمستوى عال من التنظيم والجودة. (ج) العمل على وضع برنامج جماعي للتوجيه و الإرشاد للطلاب المبدعين.

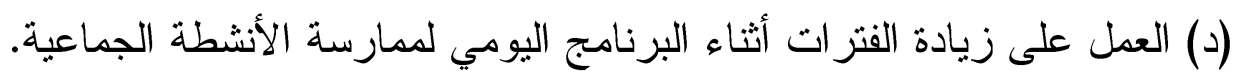

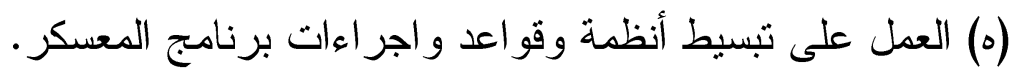
(و) الابتعاد عن التثدد في تنفيذ برنامج المعسكر.

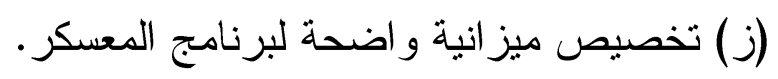

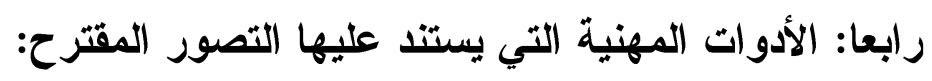
1- المناقثات الجماعية: وهي لكساعدة الطلاب على تعديل اتجاهاتهم الخاطئة نحو الابداع، مع اتاحة الفرصة لعرض تجاربهم.

ץ- الحلقات النقاثية: وهي لمساعدة الطلاب المبتكرين على تنمية فن الحوار لديهم في مناقثة

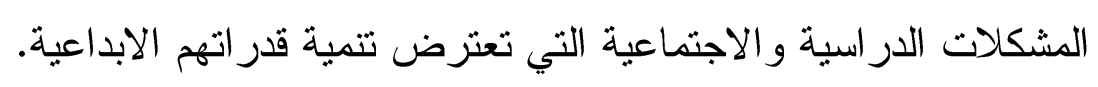

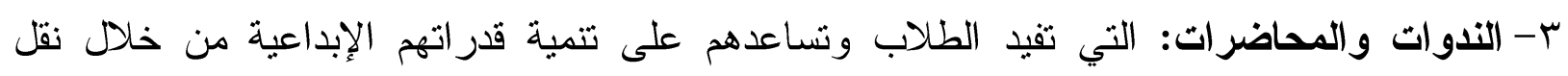
الخبرات التي تساهم في مواجهة مشكلات الطلاب. 


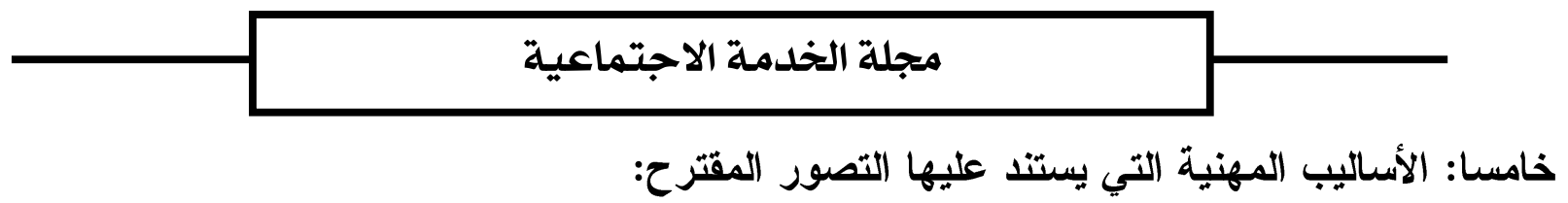

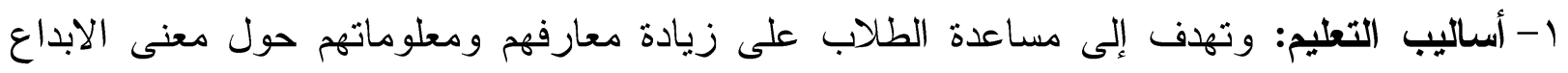

$$
\text { و وأهد افهـ. }
$$

r- أساليب التثجيع: وهي تتمثل في تثجيع الطلاب على الاهتمام بتوظيف المعلومات أكثر من الاهتمام بالمعلومة نفسها مع ضرورة اظهي وتهار مو اهبهم و ابتكار اتهم.

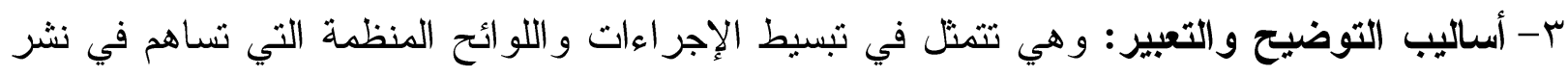

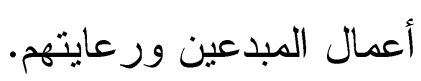

سادسا: المهارات التي يعتمد عليه التصور المقترح: 1-مهارة الاتصال: وذلك من خلال اتاحة الفرصة للطلاب على تكوين علاقات إيجابية ناجحة تساهم الفاله في تنمية قدر اتهم و المساهمة في تتمية المجتمع. r-مهارة الاقتاع: وهي القدرة على اقناع الطلاب بالاستخدام الأمثل للموارد و الإمكانيات المتاحة بما

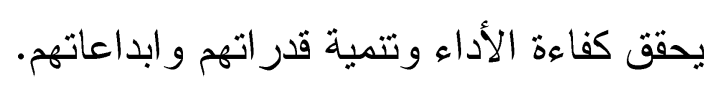
ب-مهارة التواصل: وهي حلقة اتصال بين الطلاب و القيادات من أجل تحقيق الترابط و التعاون و التقة الكتبادلة التي تساهم في تتمية قدر اتهم الإبداعية و الشباع احتياجاتهم.

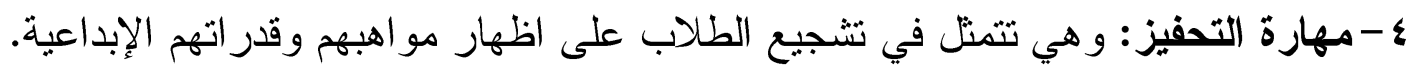

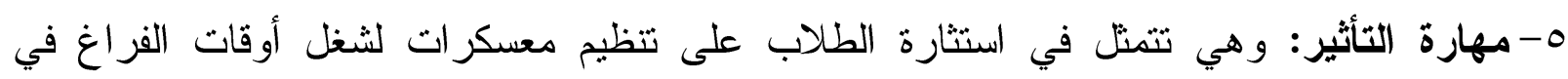
مجالات التفكير الإبداعية. سابعا: الأدوار المهنية التي يستند عليه التصور المقترح: 1- دور المرشد: وذلك لإرشاد الطلاب بمصادر الخدات التي يحتاجون اليها لتتمية قدراتهم ومهاراتهم التها

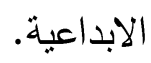
r- دور المثير: وذلك لاستثارة الطلاب بأهمية الابداع ونشر ابتكار اتهم وتطويرها. ب- دور المساعد: وذلك لمساعدة الطلاب على تقديم خذات لايهم وتوفير كافة الإمكانيات لتنتفيذ الأفكار الإبداعية. ع-دور الموجه: وذلك من خلال توجيه القيادات ووسائل الاعلام بضرورة تتمية قدرات الطلاب

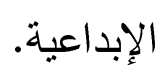
ه-دور المعلم: ويتم ذلك من خلال نقل المعلومات ببساطة للطلاب حول أهمية الابداع والبرامج و الأنشطة التي تتفذ لتتمية قدر اتهم الإبداعية. 


\section{لمـلة الخدمة الاجتماعية}

قائمة المر اجع.

1- هاشم مرعى: منطلبات تطوير الأداء المهني للأخصائيين الاجتماعيين العاملين بجمعيات تتمية المجتمع، بحث منشور بالمؤتمر العلمي السنوي السادس عشر، المجلد الثالث، كلية الخدمة الاجتماعية،

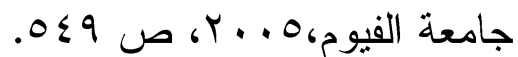

ץ-رفعت عبد المنعم عكاشة: المعسكرات كأداة في خدمة الجماعة وعلاقتها بتدعيم الانتماء لدى الثباب في ضوء المتغيرات المجتمعية المعاصرة، بحث منشور بالمؤتمر العلمي الدولي الرابع والعشرون

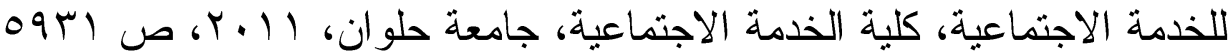

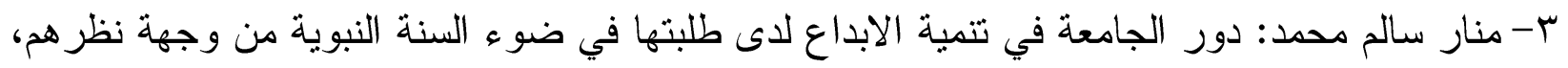

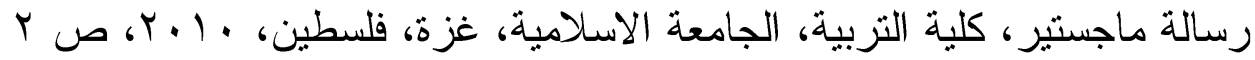

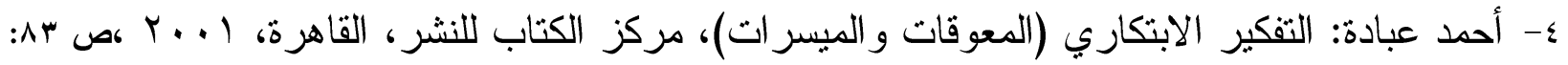
$\wedge \neg$

0- أسامة كمال أحمد: استخدام وسائل التعبير في خدمة الجماعة وتتمية التفكير الابتكاري لاى الطلاب، رسالة ماجستير غير منشورة، كلية الخدمة الاجتماعية، جامعة الفيوم A ... צ- انجود شحاتة بلواني: دور الادارة المدرسية في تتمية الابداع في المدارس الحكومية في محافظات شمال فلسطين ومعيقاتها من وجهه نظر مديريها، رسالة ماجستير غير منشورة، جامعة النجاح الوطنية، كلية الدراسات العليا، ^ ...

V- أماني محمد أهل: فعالية البرنامج المقترح لتنمية بعض الجوانب الإبداعية لدى أطفال محافظة غزة،

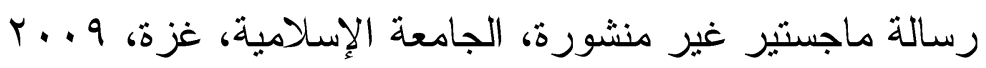

1- عبد العزيز بن سلطان العنقري: الابتكار الاستراتيجي ودوره في تحسين ممارسات إدارة الموارد البشرية: دراسة تطبيقية على قطاع الخدمات الصحية بمدينة الطائف، المجلة العربية للعلوم الإدارية،

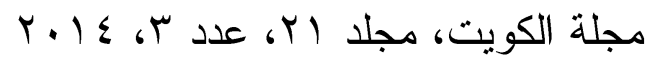

9-Małgorzata Wolska-Długosz, Stimulating the development of creativity and passion in children and teenagers in family and school environment inhibitors and opportunities to overcome them. Procedia - Social and Behavioral Sciences. Sakarya University.2015

10- Leisian Salakhatdinova. Tatiana Palei, Training Programs on Creativity and Creative Program Solving at Russian Universities. Procedia - Social and Behavioral Sciences.2015 
11- Aneta Sokół etal, Using the Internet to Enhance Teaching Process at Universities for the Development of Creativity Competencies. Procedia Social and Behavioral Sciences 186.2015

12- Francesca Saliceti, Educate For Creativity: New Educational Strategies. Procedia - Social and Behavioral Sciences 197 . 7th World Conference on Educational Sciences, (WCES-2015), 05-07 February. Athens, Greece.2015

13- M. Aichouni etal. Creativity and Innovation among Gifted Saudi Students An Empirical Study. Procedia - Social and Behavioral Sciences 195. World Conference on Technology, Innovation and Entrepreneurship.2015

14- Hessamoddin Sarooghi etal. Examining the relationship between creativity and innovation: A meta-analysis of organizational, cultural, and environmental factors. Journal of Business Venturing.2015

15- Gerhard Speckbacher ،Isabella Grabner, The cost of creativity: A control perspective. Accounting, journal homepage. Organizations and Society.2016 17- بركات محمد مراد: الطفل والقراءة الابداعية، ورقة عمل مقدمة بالمؤتمر العلمي الإقليمي

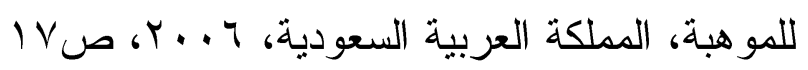

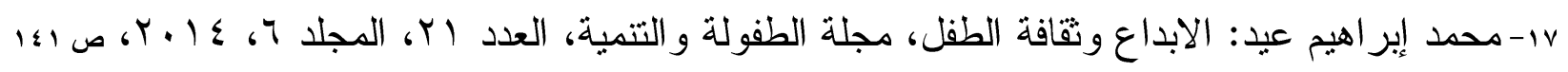

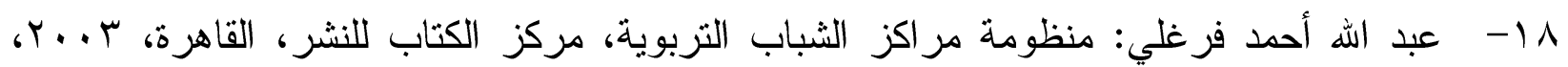
ص ص

9 1-هالة شوقي عبد الرحيم: مدى فاعلية أنشطة المعسكرات لتعديل أنماط السلوك غير المرغوب فيه

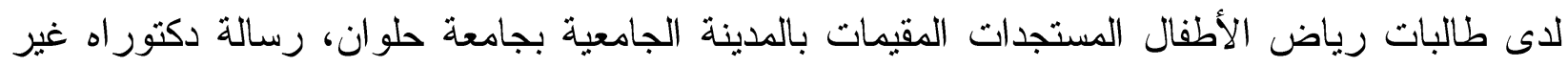

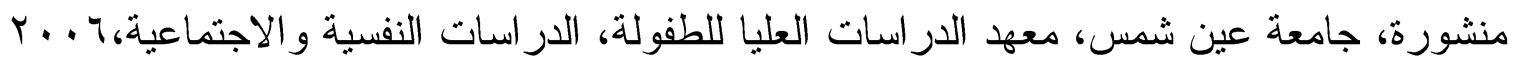
• ب-هاني رفحت عبد الراضي: خطة مقترحة لبعض الأنشطة التزويحية كمدخل لتطوير المعسكرات القومية للشباب بجمهورية مصر العربية، رسالة ماجستير غير منشورة، جامعة المنيا. كلية التربية

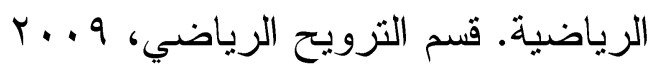




\section{لمـلة الخدمة الاجتماعية}

21-University of California, United States: youth perceptions and the design of an immersive. Research-oriented astronomy camp international journal of science Education.2009

Y Y-محمد عبد الفتاح عبد الحميد: تقويم المعسكرات القومية الصيفية في جمهورية مصر العربية رسالة

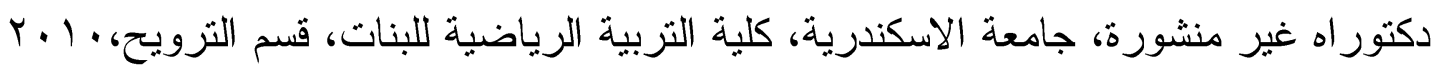
بr-احمد عبد الرؤف رجب: تقويم العمليات الادارية للمعكرات الكثفية لطلاب جامعة الاسكندرية،

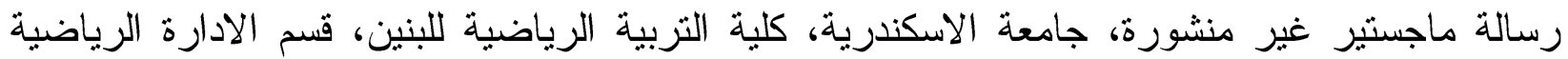

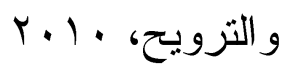
24-Anderson Butcher. Maximizing youth in community sport settings: the design and im pact of the life sports camp. College of social work. Ohio state university .united states. 2014

هץ-عمرو رمضان سعد عثمان: المشاركة في المعكرات الترويحية وعلاقتها بالمسئولية الاجتماعية وتقدير الذات لاى طلاب جامعة المنصورة، رسالة غير منشورة، جامعة المنصورة، كلية التزبية

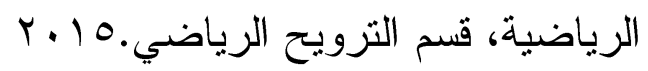
بץ-أحمد جهاد جمعة بحري: تقويم برنامج المعسكر الكثفي لطلاب المرحلة المتوسطة في جمهورية العراق، رسالة ماجستير غير منشورة، جامعة المنصورة، كلية التربية الرياضية، قسم الترويح الرياضي، لهيك r.17

V V-Tمد عبد المنعم خفاجي: تتمية الابداع الأدبي لدى الشباب، بحث منشور بمجلة التربية، قطر، المجلد

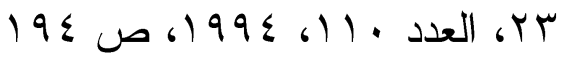

^ץ-خيري خليل الجميلي: دور الخدمة الاجتماعية ووسائل الاعلام في تتمية القدرات الابتكارية للأطفال من منظور تكاملي، بحث منشور بالمؤتمر العلمي الرابع عشر، كلية الخدمة الاجتماعية، جامعة حلوان،

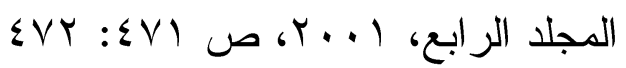

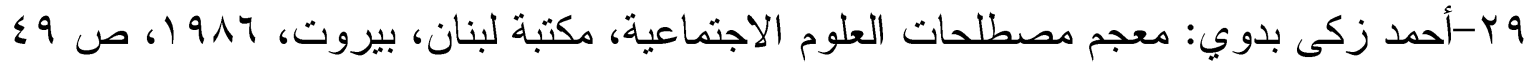

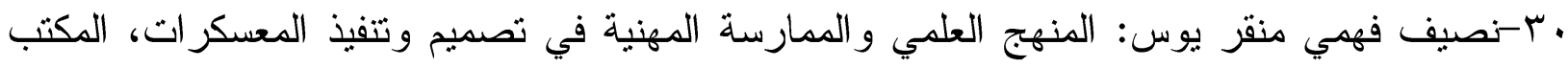

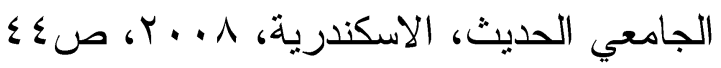




\section{口ـمجلة الخدمة الاجتماعية}

اس-على على التمامي: فعالية المعسكرات التذريبية في تنمية المهارات القيادية لطلاب الخدمة الاجتماعية، بحث منشور بالمؤتمر العلمي الدولي الرابع والعشرون للخدمة الاجتماعية، كلية الخدمة

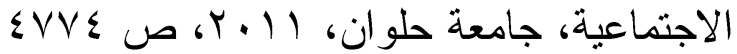

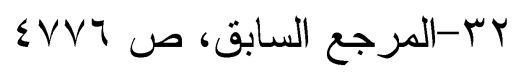

سب-جمال شحاته حبيب: دور المعسكرات التدريبية في الاعداد المهني لطلاب الخدمة الاجتماعية، بحث

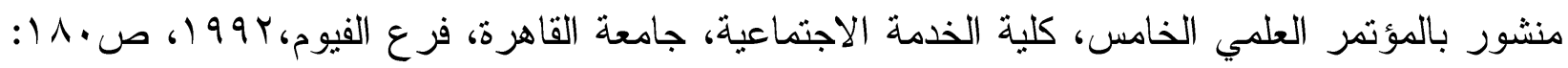
$1 \wedge 1$

ـ ז-طارق محمد السويدان، محمد أكرم العدلونى: مبادئ الابداع، مهندسو الحياة، ع .. r، ص 11 هب-ألكسندر روشكا، ترجمة غسان عبد الحي أبو فخر: الابداع العام والخاص، عالم المعرفة، المجلس

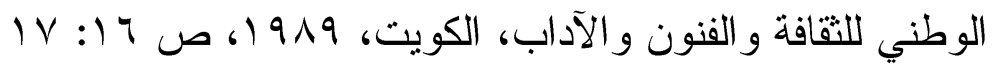
36-Eleni Sefertzi. Creativity. Report produced for the EC funded project. INNOREGIO: dissemination of innovation and knowledge management techniques.2000. p.2

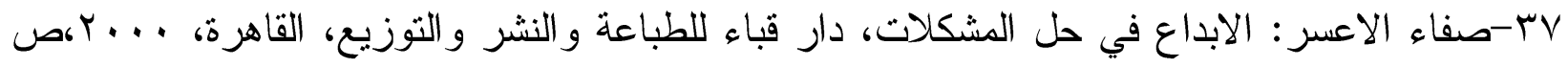

یז-ريمة الخانى: مفهوم الابداع، بحث منشور بمجلة فكر، مركز العبيكان للنشر والتوزيع، السعودية،

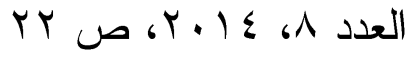

qس-محمد عبد الغنى حسن هلال: مهارات التفكير الابتكاري، مركز تظوير الاداء والتتمية، القاهرة، N) ص (199V • ـ-ابر اهيم بن أحمد مسلم الحارثي: قياس الموهبة والابداع، ورقة عمل مقدمة بالمؤتمر العلمي الإقليمي

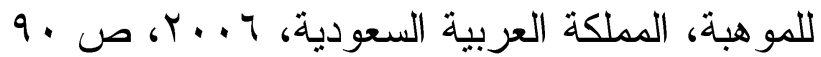

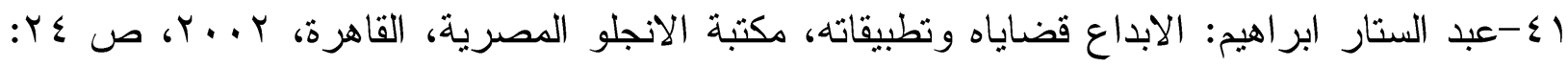

Y ץ-عاطف عوض: أثر تطبيق عناصر الابداع الإداري في التطوير التنظيمي، مجلة جامعة دمشق للعلوم

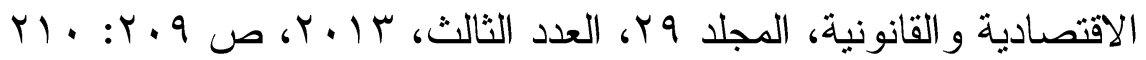

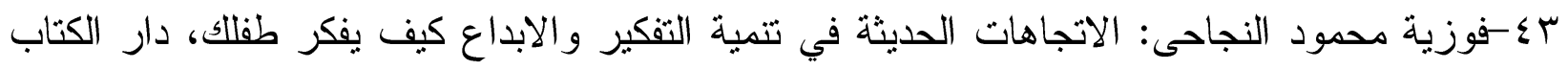

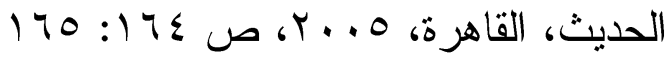




\section{لمـلة الخدمة الاجتماعية}

44-Eleni Sefertzi. Op.cit.p.2

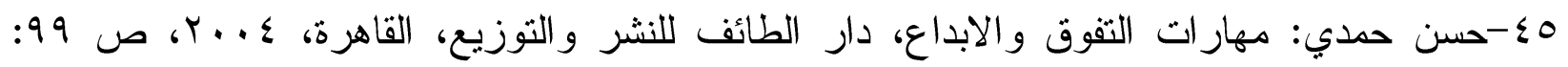
$1 \ldots$ بـ "كر اجي عنايت: الابتكار • و المستقبل فكر جديد لمجتمع جديد، نهضة مصر للطباعة والنشر و التوزيع،

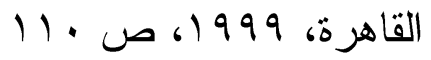
V V

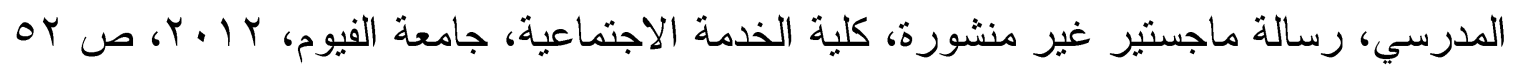
1 ـ-محمد دسوقي حامد: دراسة تحليلية للأساليب التي يستخدمها أخصائي الجماعة لنطوير نمط التفكير لجماعات الأطفال و أعضائها، بحث منشور بمجلة دراسات في الخدمة الاجتماعية و العلوم الإنسانية، دار

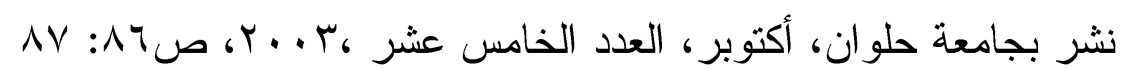

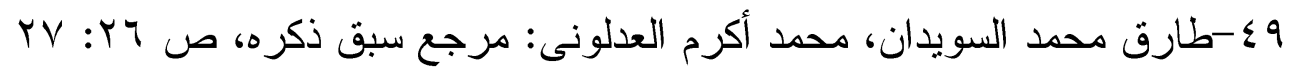
.0 90. إ-محمد عبد الله البيلي: دور " جمعية الامارات للموهوبين " في رعاية شؤون الموهوبين في دولة الامارات العربية المتحدة، ورقة عمل مقدمة بالمؤتمر العلمي الإقليمي للموهبة، المملكة العربية السعودية،

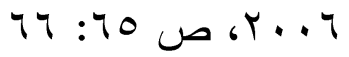

ror-مفيق عطية توفيق: الابداع الإداري وعلاقته بالأداء الوظيفي لمديري القطاع العام “در ساة تطبيقية على وزارات قطاع غزة، رسالة ماجستير غير منشورة، الجامعة الاسلامية بغزة، فلسطين، كلية التجارة، IV מ. . . T به-أحمد ذكي بدوي: معجم مصطلحات الرعاية و التنمية الاجنماعية، دار الكتاب المصري، القاهرة، rAV ص (19AV

54-Oxford English dictionary, clarendon press, 1993, p.518

00-أحمد شفيق السكرى: قاموس الخدمة الاجتماعية والخدمات الاجتماعية، دار المعرفة الجامعية،

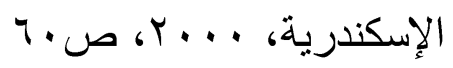

به-محمد الظريف سعد: العلاقة بين استخدام تكنيك المشروعات الجماعية في خدمة الجماعة وتتمية المسؤولية البيئية لدى الثباب الجامعي، بحث منشور بالمؤتمر الحادي عشر، كلية الخدمة الاجتماعية،

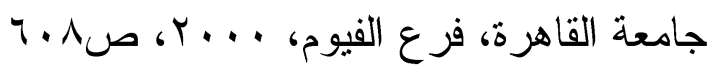




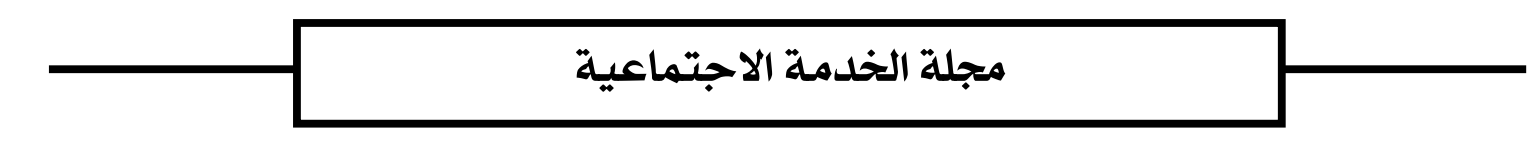

Vه-أحمد حمدي شورة: اتجاهات الشباب الجامعي نحو برامج تتمية المجتمع المحلى في ضوء الأهداف

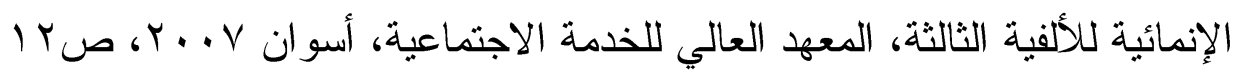

